\title{
Perspective on the response of marine calcifiers to global warming and ocean acidification-Behavior of corals and foraminifera in a high $\mathrm{CO}_{2}$ world "hot house"
}

Hodaka Kawahata ${ }^{1,2^{*}}$, Kazuhiko Fujita ${ }^{3}$, Akira Iguchi ${ }^{2}$, Mayuri Inoue ${ }^{4}$, Shinya Iwasaki ${ }^{5}$, Azumi Kuroyanagi ${ }^{6}$, Ayumi Maeda ${ }^{1}$, Takuya Manaka ${ }^{7}$, Kazuyoshi Moriya ${ }^{8}$, Haruka Takagi ${ }^{1}$, Takashi Toyofuku ${ }^{5}$, Toshihiro Yoshimura ${ }^{5}$ and Atsushi Suzuki ${ }^{2}$

\begin{abstract}
The $\mathrm{CO}_{2}$ concentration of air has increased over the last two centuries and recently surpassed $400 \mathrm{ppm}$. Carbon cycle models project $\mathrm{CO}_{2}$ concentrations of 720 to $1000 \mathrm{ppm}$ for the IPCC intermediate scenario (RCP 6.0), resulting in an increase in global mean temperature of $\sim 2.6^{\circ} \mathrm{C}$ and a decrease in seawater $\mathrm{pH}$ of $\sim 0.3$. Together, global warming and ocean acidification are often referred to as the "evil twins" of climate change, potentially inducing severe threats in the near future. In this paper, our discussion is focused on the response of two major calcifiers, foraminifera and corals, which contribute much to the global carbonate burial rate. Photosymbiosis is regarded as an adaptive ecology for living in warm and oligotrophic oceans, especially for reef-building corals and larger reefdwelling benthic foraminifera. As a consequence of global warming, bleaching may be a global threat to algal symbiont-bearing marine calcifying organisms under conditions of high temperature and light intensity. If $\mathrm{CO}_{2}$ is dissolved in seawater, the partial pressure of $\mathrm{CO}_{2}$ in seawater $\left(\mathrm{pCO}_{2}\right)$ and dissolved inorganic carbon (DIC) increases while $\mathrm{pH}$ and the saturation state of carbonate minerals decreases without any change in total alkalinity. Generally, marine calcifying organisms show decreases in calcification rates in response to acidified seawater. However, the response often differs depending on situations, species, and life-cycle stage. Some benthic foraminifera showed a positive response to low pH conditions. The Acropora digitifera coral calcification of adult branches was not reduced markedly at higher $p \mathrm{CO}_{2}$ conditions, although calcification tended to decrease versus $p \mathrm{CO}_{2}$ in both aposymbiotic and symbiotic polyps. New analytical technologies help identify important constraints on calcification processes. Based upon $\mathrm{Ca}$ isotopes, the transport path of $\mathrm{Ca}^{2+}$ and the degree of its activity would predominantly control the carbonate precipitation rate. Visualization of the extracellular $\mathrm{pH}$ distribution shows that proton pumping produces the high internal pH and large internal-external pH gap in association with foraminiferal calcification. From the perspective of a long-term change in the Earth's surface environment, foraminifera seem to be more adaptive and robust than corals in coping with ocean warming and acidification but it is necessary to further understand the mechanisms underlying variations in sensitivity to heat stress and acidified seawater for future prediction. Since $\mathrm{CO}_{2}$ is more soluble in lower temperature seawater, ocean acidification is more critical in the polar and high-latitude (Continued on next page)
\end{abstract}

\footnotetext{
* Correspondence: kawahata@aori.u-tokyo.ac.jp

${ }^{1}$ Atmosphere and Ocean Research Institute, The University of Tokyo, 5-1-5

Kashiwanoha, Kashiwa, Chiba 277-8564, Japan

${ }^{2}$ Geological Survey of Japan, National Institute of Advanced Industrial

Science and Technology (AIST), Higashi 1-1-1, Tsukuba, Ibaraki 305-8567,

Japan

Full list of author information is available at the end of the article
} 


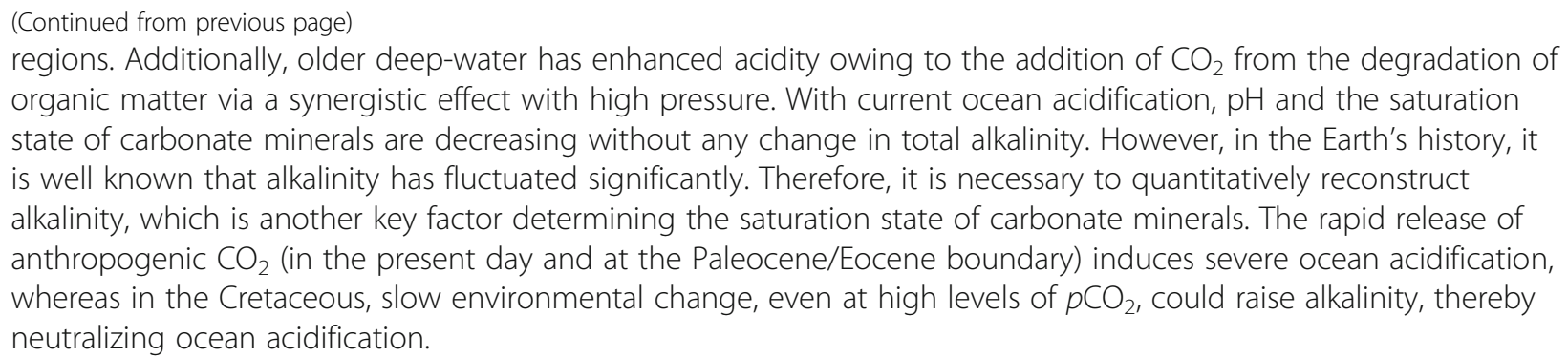

Keywords: Partial pressure of $\mathrm{CO}_{2}$, Global warming, Ocean acidification, Coral, Foraminifera, Bleaching, Calcite, Aragonite, Saturation state, Organic matter, Alkalinity, Carbon cycle

\section{Introduction}

Human beings are now dramatically changing our planet and altering the environment by modifying the global carbon cycle through anthropogenic carbon dioxide $\left(\mathrm{CO}_{2}\right)$ emissions from the burning of fossil fuels. The $\mathrm{CO}_{2}$ concentration of air was around $280 \mathrm{ppm}$ in $1750 \mathrm{AD}$ (the beginning of Industrial Revolution), but it has increased over the last two centuries and is currently above $400 \mathrm{ppm}$. Carbon dioxide is one of the primary greenhouse gases in Earth's atmosphere, together with water vapor, methane, nitrous oxide, and others. The Intergovernmental Panel on Climate Change (IPCC) intermediate RCP 6.0 scenarios (IPCC 2013b) predicts that the $\mathrm{CO}_{2}$ concentration in air will increase to $720-1000 \mathrm{ppm}$ by $2100 \mathrm{AD}$ and that the global mean temperature will rise by $2.6{ }^{\circ} \mathrm{C}$. Comparison of $\mathrm{CO}_{2}$ concentrations in the atmosphere with fossil-fuel burning data indicates that about $60 \%$ of fossil-fuel emissions remain in the air. The remainder is mainly absorbed by the ocean, which may provide some relief from severe warming.

Atmospheric carbon reservoirs are controlled by the formation/dissolution of both carbonate and organic matter $(\mathrm{OM})$ in the ocean, which changes the chemical equilibrium of the marine $\mathrm{CO}_{2}$ system by removing/adding alkalinity in association with the release/absorbance of $\mathrm{CO}_{2}$ in the atmosphere (Fig. 1) (e.g., Kleypas et al. 1999; Kleypas et al. 2006; Orr et al. 2005). In open ocean, biogenic carbonate production is positively correlated with biogenic OM production, although the carbon ratios of OM to carbonate generally increase as $\mathrm{OM}$ fluxes increase (based upon the results from sediment trap experiments in the Pacific Kawahata 2002). Planktic foraminifera, which live in the ocean surface layers from tropical to polar regions, secrete low-Mg calcite shells and contribute $32-80 \%$ of the total deep-marine calcite budget in the global carbonate cycle (Schiebel 2002). The comparable carbonate contributor in the open ocean is coccolithophore. This is a unicellular, eukaryotic phytoplankton (alga) and one of the more abundant primary producers in the ocean, especially in tropical and subtropical oceans influenced by
El Nino/Southern Oscillation phenomena (e.g., Beaufort and Grelaud 2017).

In oligotrophic environments such as coral reefs and subtropical gyres in the Pacific, the symbiotic relationship between the host and its symbiotic algae presents three major advantages: energy from photosynthesis, an enhancement of calcification, and uptake of host metabolites. Bleaching is defined as (i) damage to the symbiotic relationships between hosts and algal symbionts and (ii) photosynthetic pigment loss (Iglesias-Prieto et al. 1992). Elevated seawater temperature brings negative effects on marine calcifiers; in particular, coral bleaching has occurred repeatedly since 1979 AD (e.g., Bunkley-Williams and Williams 1990) in tropical regions worldwide (Brown 1997; HoeghGuldberg et al. 2007). Mass bleaching events such as those in 1979-1980 AD, 1982-1983 AD, and 1986-1988 AD provide important opportunities for investigating the influence of bleaching during the early stages of this research area. Recently, bleaching has been found in benthic foraminifera in coral reefs (Schmidt et al. 2011). Coral reefs are among the ecosystems most vulnerable to environmental stresses associated with future climate changes caused by human activities (IPCC 2017).

By the end of twenty-first century, the surface waters of the ocean could be more acidic, resulting in an undersaturation condition with respect to carbonate minerals in some areas of high latitude. Ocean acidification (OA) will induce severe stress in calcifiers, some of which are sensitive to environmental changes at global and local levels. Additionally, Oschlies et al. (2008) pointed out that anthropogenic $\mathrm{CO}_{2}$ emissions will extend oxygen-minimum zones, a $50 \%$ increase in the suboxic (defined as dissolved $\mathrm{O}_{2}<5 \mathrm{mmol} \mathrm{m}^{-3}$ ) water volume by the end of this century, although a serious ocean anoxic event, which occurred in the Cretaceous, will not occur in the normal open ocean. Drivers such as OA, higher seawater temperature, or reduced dissolved oxygen concentration may overlap to amplify ecosystem impacts.

Therefore, understanding the effect of environmental parameters (i.e., temperature, salinity, $\mathrm{pH}$, and dissolved 


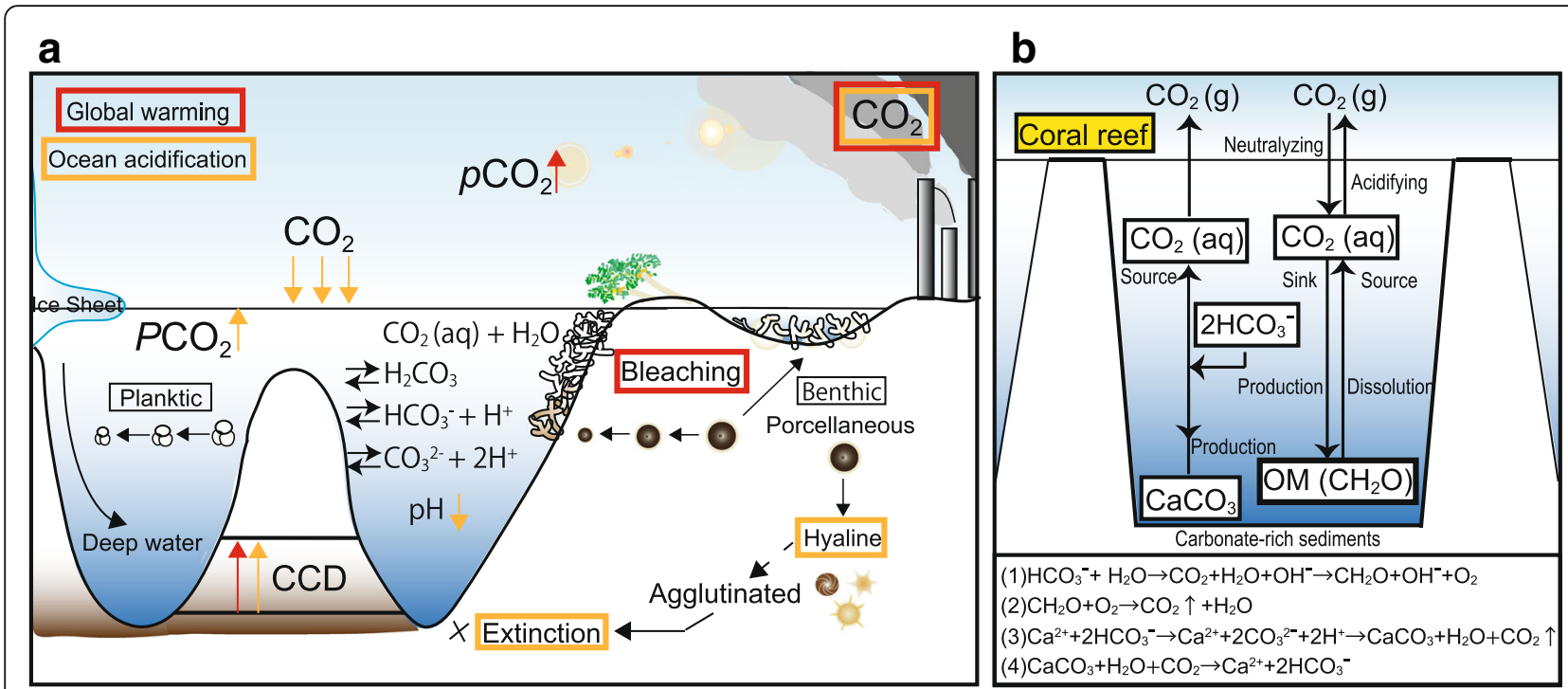

Fig. 1 a Schematic diagram of modern carbon cycle for both global warming and ocean acidification, which are often referred to as the "evil twins" of climate change. The increase in atmospheric $\mathrm{CO}_{2}$ concentration caused by human activities is predicted to promote global warming by $\sim 2.5^{\circ} \mathrm{C}$ and an ocean $\mathrm{pH}$ reduction of $\sim 0.3$ by $2100 \mathrm{AD}$. Coral reefs are among the ecosystems most vulnerable to environmental stresses (bleaching and/or ocean acidification). An aragonite saturation state of 3.3 is suggested to be the environmental limit for the existence of tropical coral reefs where calcification exceeds the dissolution of calcium carbonate (Kleypas et al. 2006). The culture experiments reported general negative effects on survival, calcification, growth, and reproduction despite significant variation among taxonomic groups in marine environments. For example, calcification tended to decrease versus $\mathrm{pCO}_{2}$ in both aposymbiotic and symbiotic polyps of Acropora digitifera, although its coral calcification of adult branches was not reduced so much under higher $\mathrm{PCO}_{2}$ conditions. In contrast to the majority of benthic foraminifers dwelling in coral reefs, Calcarina gaudichaudii showed a positive response to increases in $\mathrm{pCO}_{2}$. Since $\mathrm{CO}_{2}$ is more soluble in lower temperature seawater, ocean acidification is more critical in the polar and high-latitude regions. Surface water in the Southern Ocean will be undersaturated with respect to aragonite by 2050 AD (Orr et al. 2005). More severe dissolution of carbonate will occur in deep-sea due to the increase in solubility at higher pressure, which will make the CCD shallow. Most likely, deep-sea benthic foraminifera will be forced to change from calcareous to the agglutinated forms reported at the Paleocene/Eocene boundary. $\mathbf{b}$ Schematic diagram of the carbon cycle in coral reefs. The equations involve the following important processes: (1) photosynthesis ( $\mathrm{CO}_{2}$ invasion, resulting in slowing acidification), (2) respiration/degradation $\left(\mathrm{CO}_{2}\right.$ evasion, promoting acidification), (3) calcification ( $\mathrm{CO}_{2}$ evasion), and (4) dissolution of carbonate ( $\mathrm{CO}_{2}$ invasion, one of the neutralizing processes). Processes (1) and (2) are associated with organic carbon metabolism, whereas (3) and (4) are associated with inorganic carbon processes. Photosynthesis triggers the production of $\mathrm{OH}^{-}$, commonly resulting in the deposition of carbonate. In contrast, the reaction of carbonate with $\mathrm{CO}_{2}$ works as a sink of $\mathrm{CO}_{2}$. This reaction is often promoted in deep-sea, which results in the depletion of carbonate on abyssal plains in the Pacific

oxygen concentration) on representative calcifiers such as corals and foraminifera is essential for the verification of carbonate cycles and future environments. In the global carbonate budget, the carbonate production rates in the ocean and the tropical shelves are estimated to be $\sim 1.0 \mathrm{Pg}$ $\mathrm{C}$ year $^{-1}$ and $\sim 0.17 \mathrm{PgC}$ year $^{-1}$, respectively. However, its burial rate to sediments in the ocean is $\sim 0.15 \mathrm{Pg} \mathrm{C}_{\text {year }}{ }^{-1}$ via $85 \%$ dissolution in water column/surface sediments; this is comparable to that in the tropical shelves $\left(\sim 0.13 \mathrm{Pg} \mathrm{C}_{\text {year }}{ }^{-1}\right)$. Foraminifera, coccolithophores, and pteropods accounted for $43 \%, 22 \%$, and $34 \%$, respectively, in the ocean (personal communication with Prof. Tim Rixen). Of these, pteropods often produce aragonite shells, which are more liable to dissolution. Our discussion is focused on two major calcifiers, foraminifera and corals, although OA may impact other groups of marine organisms (e.g., Iglesias-Rodriguez et al. 2002; Catubig et al. 1998; Gangsto et al. 2008; Tambutté et al. 2011).

In this review, initially, we describe the general features of the marine carbonate system and biotic and abiotic carbonate minerals. In the next section, we summarize the response of corals and foraminifera to OA. Photosymbiosis is regarded as an adaptive ecology for living in warm and oligotrophic oceans and also enhances calcification of the host's skeleton (e.g., Stanley Jr. 2006; Moya et al. 2008). Therefore, it is believed to facilitate the prosperity of calcifying organisms in such environments. After discussing the role of symbiosis, we report the latest results on coral and foraminiferal bleaching including culture experiments, and then discuss the responses of symbiont-bearing calcifiers in a warm and/or high $\mathrm{CO}_{2}$ world. New chemical and isotope analyses of biominerals, together with visualization techniques for extracellular $\mathrm{pH}$ distribution, provide valuable information regarding biomineralization including calcification. Furthermore, the latest results on carbonate dissolution using X-ray micro-computed tomography will be presented. Finally, we discuss results on the response of calcifiers to different environments such as extreme warmth in the Cretaceous, the middle Eocene climatic optimum (MECO) event, and 
perturbations in the global carbon cycle at the Paleocene/ Eocene boundary. This discussion includes the interaction between terrestrial and marine environments to better understand the key factors inducing $\mathrm{OA}$ in the past and the near future.

\section{Background to ocean acidification}

When $\mathrm{CO}_{2}$ is dissolved in seawater, chemical reactions reduce seawater $\mathrm{pH}$, carbonate ion concentration $\left(\left[\mathrm{CO}_{3}{ }^{2-}\right]\right)$, and the saturation states of biogenic carbonate minerals (Fig. 1):

$$
\begin{gathered}
\mathrm{CO}_{2(\mathrm{aq})}+\mathrm{H}_{2} \mathrm{O} \rightleftarrows \mathrm{H}_{2} \mathrm{CO}_{3} \rightleftarrows \mathrm{HCO}_{3}{ }^{-} \\
+\mathrm{H}^{+} \rightleftarrows \mathrm{CO}_{3}{ }^{2-}+2 \mathrm{H}^{+}
\end{gathered}
$$

These chemical reactions are termed "ocean acidification (OA)." The seawater $\mathrm{pH}$ of surface ocean waters was 8.17 at $1750 \mathrm{AD}$ but this has decreased to 8.06 in the present day and is expected to reach to 7.93 $\left(p \mathrm{CO}_{2}=560 \mu \mathrm{atm}\right)$ or $7.71\left(p \mathrm{CO}_{2}=1000 \mu \mathrm{atm}\right)$ in the near future (Gattuso et al. 1998). OA is known as "climate change's equally evil twin", in reference to the significant and harmful consequence of enhanced $\mathrm{CO}_{2}$ in the atmosphere. As the $\mathrm{pH}$ scale is logarithmic, a change of $1.0 \mathrm{pH}$ unit represents approximately a $30 \%$ increase in acidity.
Foraminifera, corals, haptophytes, mollusks, and sea urchins produce skeleton structures of carbonate, mainly in the mineral form of aragonite and high and low magnesium $(\mathrm{Mg})$ calcites. Of these, foraminifera, corals, and haptophytes are the most important organisms forming large amounts of carbonate rock, calcareous sediment, and coral reef; thus hosting one of the richest and most diverse ecosystems of our planet (Kleypas et al. 1999). Both carbonate formation and OM production play important roles in controlling the amount of $\mathrm{CO}_{2}$ in the oceans and atmosphere. Generally speaking, OM production and degradation work as a sink and a source of $\mathrm{CO}_{2}$, respectively. Conversely, carbonate formation in the sea via the combination of calcium ions $\left(\mathrm{Ca}^{2+}\right)$ and $\mathrm{HCO}_{3}{ }^{-}$liberates $\mathrm{CO}_{2}$, whereas its dissolution works as a sink of $\mathrm{CO}_{2}$ (Fig. 2). Additionally, the chemical weathering of terrestrial rocks plays an important role in the long-term global carbon cycle (Sarmiento and Gruber 2006). The weathering of both carbonate and silicate rocks consumes atmospheric $\mathrm{CO}_{2}$ and generates bicarbonate $\left(\mathrm{HCO}_{3}{ }^{-}\right)$, which is transported to the ocean and released back to the atmosphere in the form of $\mathrm{CO}_{2}$ through oceanic carbonate mineralization processes (Eq. 3 in Fig. 1):

$$
\begin{gathered}
\mathrm{CaSiO}_{3}+2 \mathrm{CO}_{2}+\mathrm{H}_{2} \mathrm{O} \rightarrow \mathrm{Ca}^{2+}+2 \mathrm{HCO}_{3}{ }^{-}+\mathrm{SiO}_{2} \\
\mathrm{CaCO}_{3}+\mathrm{CO}_{2}+\mathrm{H}_{2} \mathrm{O} \rightarrow \mathrm{Ca}^{2+}+2 \mathrm{HCO}_{3}{ }^{-}
\end{gathered}
$$
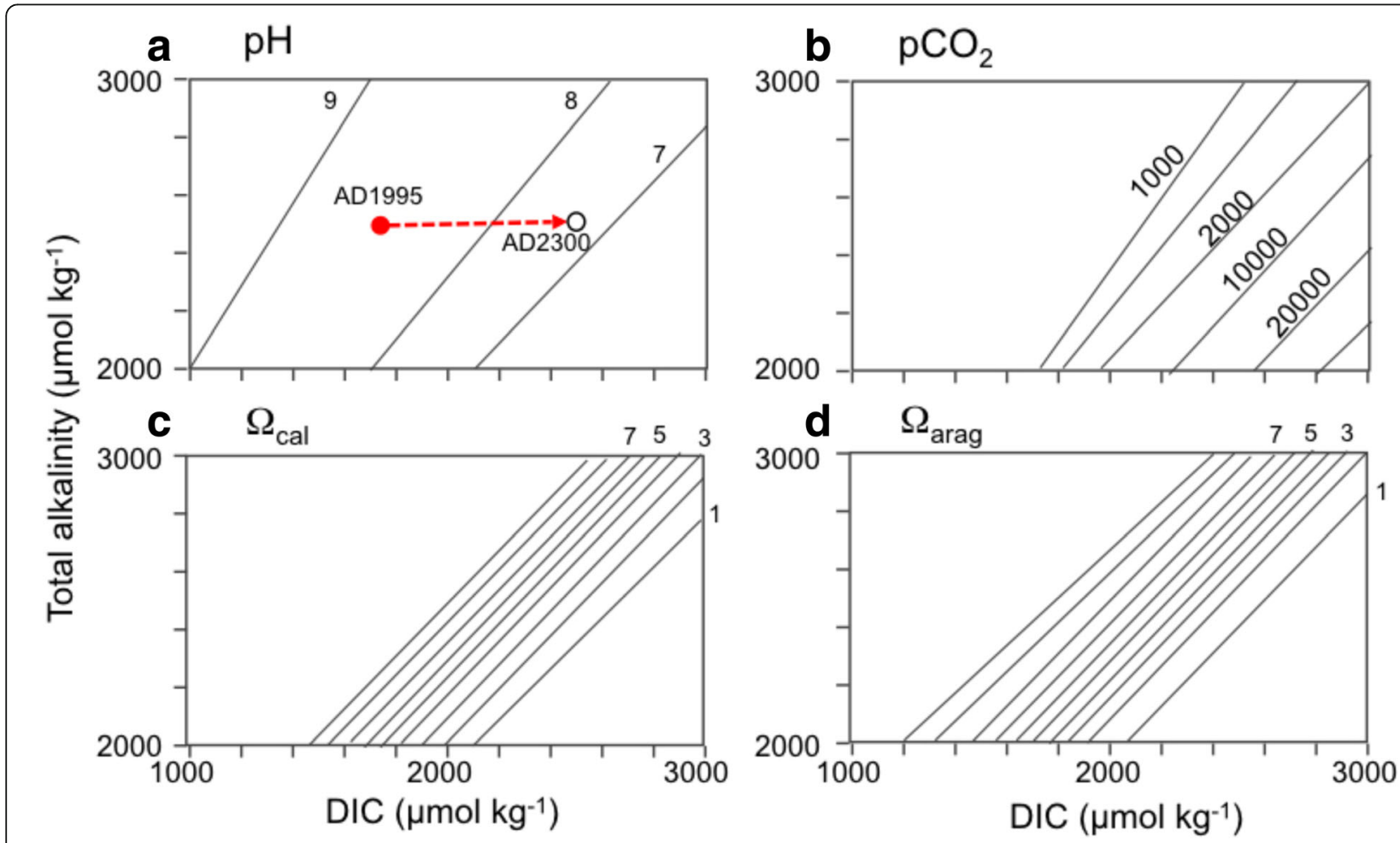

Fig. 2 Total alkalinity and dissolved inorganic carbon (DIC) diagrams showing contours of pH (a), partial pressure of CO2 (b), and saturation states of aragonite ( $\Omega$ arag; c) and calcite $(\Omega \mathrm{cal} ; \mathbf{d})$. Chemistry of surface water under modern conditions (solid red circle) at St. $96\left(5^{\circ} 00^{\prime} \mathrm{N}, 144^{\circ} 55.7^{\prime} \mathrm{E}\right.$; data are available from http://pacifica.pices.jp/table/) will be modified in 2300 AD (open circle) 
Silicate and carbonate weathering in this sequence of processes consumes the difference in the molar ratio of $\mathrm{CO}_{2}$. Over long timescales ( $10^{4}$ to $10^{6}$ years), it is suggested that only silicate weathering contributes to a net reduction of atmospheric $\mathrm{CO}_{2}$ concentrations, which are closely linked to past climate conditions (Berner 1992; Brady 1991).

\section{Review}

\section{Basics of ocean acidification}

$\mathrm{OA}$ is in essence a $\mathrm{CO}_{2}$-related phenomenon in the ocean. Therefore, its basic physicochemical characteristics can be well illustrated by chemical equilibrium modeling of the $\mathrm{CO}_{2}$ system in seawater (Figs. 2, 3, 4, and 5, Table 1).

\section{General features of the carbonate system}

Dissolved inorganic carbon (DIC $=\left[\mathrm{CO}_{2}\right]+\left[\mathrm{HCO}_{3}{ }^{-}\right]+$ $\left.\left[\mathrm{CO}_{3}{ }^{2-}\right]\right)$ and total alkalinity $\left(\mathrm{TA}=\left[\mathrm{HCO}_{3}{ }^{-}\right]+2\left[\mathrm{CO}_{3}{ }^{2-}\right]+\right.$ $\left[\mathrm{B}(\mathrm{OH})_{4}{ }^{-}\right]+\left[\mathrm{OH}^{-}\right]+2\left[\mathrm{PO}_{4}{ }^{3-}\right]+\left[\mathrm{HPO}_{4}{ }^{2-}\right]+\left[\mathrm{SiO}(\mathrm{OH})_{3}{ }^{-}\right]$ $\left.-\left[\mathrm{H}^{+}\right]-\left[\mathrm{HSO}_{4}^{-}\right]\right)$are the most important parameters in the aquatic $\mathrm{CO}_{2}$ system because they are essential for representation of the laws of conservation of mass and electricity. A cross plot of DIC and TA is known as the Deffeyes' diagram (Deffeyes 1965). $\mathrm{pH}$ and $p \mathrm{CO}_{2}$ can be shown in the contours in the DIC and TA plane because these parameters are functions of DIC and TA (Figs. 2 and 3). The four parameters, DIC, TA, pH, and $p \mathrm{CO}_{2}$, are all measurable parameters in the marine $\mathrm{CO}_{2}$ system. More importantly, OA is expressed as a horizontal vector in the Deffeyes' diagram (DIC-TA plot), as shown in Fig. 2. OA is the result of increased oceanic $\mathrm{CO}_{2}$ uptake by continuing anthropogenic emissions. $\mathrm{CO}_{2}$ dissolution in seawater increases DIC but causes no changes in TA (Table 1).

The conditions of under- and super-saturation of seawater with respect to calcium carbonate $\left(\mathrm{CaCO}_{3}\right)$ are represented by calcium carbonate solubility $(\Omega)$, which is defined as the ratio of the product of the solutes over the product of the solutes at saturation (solubility product):

$$
\begin{aligned}
\Omega & =\left[\mathrm{CO}_{3}{ }^{2-}\right]\left[\mathrm{Ca}^{2+}\right] /\left[\mathrm{CO}_{3}{ }^{2-}\right]_{\text {sat }}\left[\mathrm{Ca}^{2+}\right]_{\text {sat }} \\
& =\left[\mathrm{CO}_{3}{ }^{2-}\right]\left[\mathrm{Ca}^{2+}\right] / \mathrm{K}_{\mathrm{sp}}
\end{aligned}
$$

where $\left[\mathrm{CO}_{3}{ }^{2-}\right]_{\text {sat }}$ and $\left[\mathrm{Ca}^{2+}\right]_{\text {sat }}$ are, respectively, the concentrations of carbonate and dissolved $\mathrm{Ca}^{2+}$ in equilibrium with carbonate mineral $\left(\mathrm{CaCO}_{3}\right) \cdot\left[\mathrm{CO}_{3}{ }^{2-}\right]$ and $\left[\mathrm{Ca}^{2+}\right]$ are the observed $\mathrm{CO}_{3}{ }^{2-}$ and $\mathrm{Ca}^{2+}$ concentrations. $\left[\mathrm{CO}_{3}{ }^{2-}\right]$ is

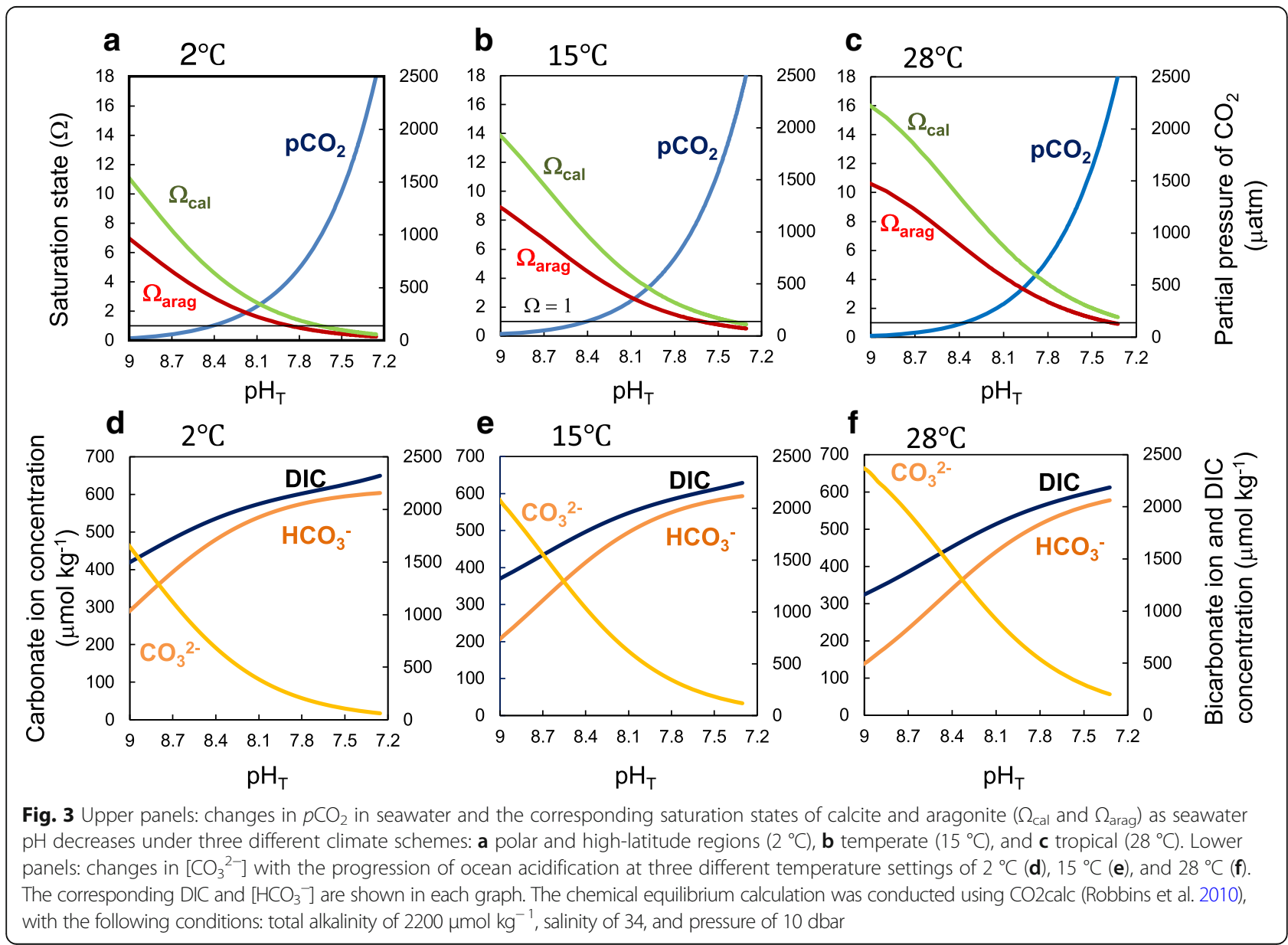




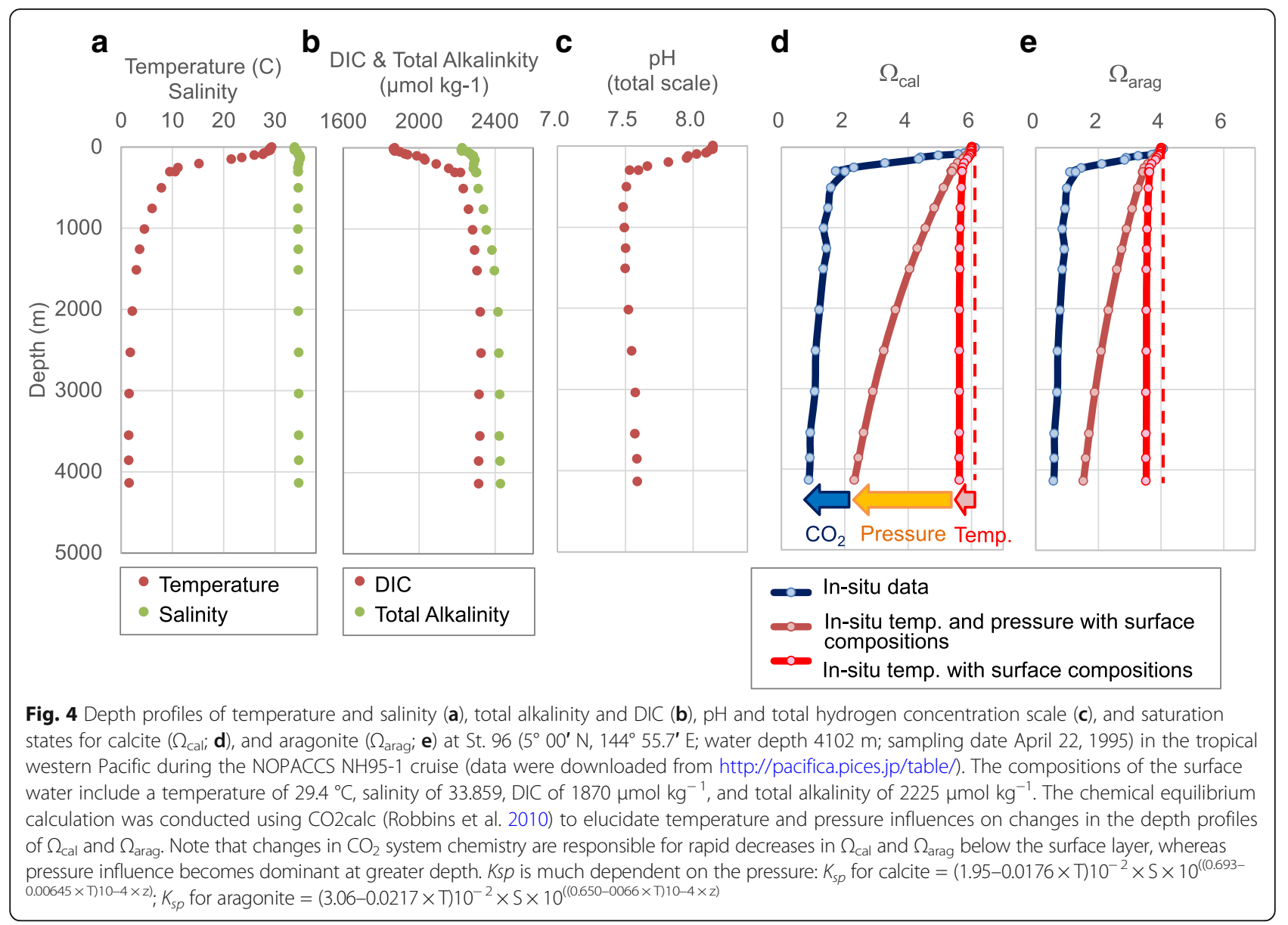

closely related to the acidity of seawater. $K_{\mathrm{sp}}$ is the solubility product, which is dependent on temperature, salinity, pressure, $\mathrm{pH}$, and nutrient levels. The term $\Omega$ is also known as the carbonate saturation state and is calculated for both calcite and aragonite $\left(\Omega_{\text {cal }}\right.$ and $\Omega_{\text {arag }}$, Robbins et al. 2010). When $\Omega>1$, seawater is supersaturated with respect to carbonate minerals; conversely, when $\Omega<1$, seawater is undersaturated. Because $\left[\mathrm{Ca}^{2+}\right]$ in the ocean has a long residence time $\left(10^{6}\right.$ years), it can be assumed to be constant on a time scale shorter than $10^{4}$ years. $\left[\mathrm{Ca}^{2+}\right]$ is assumed to be proportional to the salinity level. Therefore, the carbonate saturation state $(\Omega)$ is mainly determined by $\left[\mathrm{CO}_{3}{ }^{2-}\right]$ and $K_{\mathrm{sp}}$ (Table 1 ).

The saturation states of calcite and aragonite $\left(\Omega_{\text {cal }}\right.$ and $\Omega_{\text {arag}}$ ) can be calculated and shown in the DIC-TA plot (Figs. 4 and 5). $\mathrm{OC}$ modifies the $\mathrm{CO}_{2}$ system, and its change is represented by the horizontal vector in the DIC-TA plot. It always results in a decrease in $\Omega$ (Table 1 ).

While OA may progress ubiquitously, the corresponding changes in $\mathrm{pH}$ and $p \mathrm{CO}_{2}$ vary locally. The most evident parameter to influence the pace of OA progression is temperature. By using the parameters for the carbonate system in the equatorial Pacific as representative, Fig. 3 summarizes the temperature effects on marine
$\mathrm{CO}_{2}$ system parameters, including the saturation states of carbonate minerals (Table 1 ). Although $p \mathrm{CO}_{2}$ is sensitive to temperature $\left(\sim 4 \%\right.$ increase per $\left.1{ }^{\circ} \mathrm{C}\right)$, this cannot be seen in the upper panels of Fig. 3. In contrast, $\Omega_{\text {cal }}$ and $\Omega_{\text {arag }}$ show large variations according to the temperature settings (Fig. $3 \mathrm{a}-\mathrm{c}$ ). $\Omega_{\text {cal }}$ of the $2{ }^{\circ} \mathrm{C}$ condition becomes lower than the critical value of 1 (carbonate dissolution) when $p \mathrm{CO}_{2}$ reaches around $750 \mu$ atm or $\mathrm{pH} 7.7$ (Fig. 3c). In contrast, $\Omega_{\text {cal }}$ for the $28{ }^{\circ} \mathrm{C}$ condition may not reach the critical value before $\mathrm{pCO}_{2}$ reaches around $2300 \mu \mathrm{atm}$ or pH 7.3 (Fig. 3c), clearly indicating that $\mathrm{OA}$ is more critical in the polar and high-latitude regions compared with temperate and tropical regions. This trend become easily understandable in light of the temperature dependency of $\left[\mathrm{CO}_{3}{ }^{2-}\right]$, as shown in the lower panels in Fig. 3d-f.

Another important factor influencing the saturation states of seawater with respect to carbonate minerals is pressure. Pressure affects carbonate solubility in seawater and thus $K_{\mathrm{sp}}$ and temperature. In order to depict the pressure effect alone, we prepared depth profiles of saturation states for calcite and aragonite at St. $96\left(5^{\circ} 00^{\prime} \mathrm{N}, 144^{\circ}\right.$ 55.7' E, water depth $4102 \mathrm{~m}$, sampling date April 22, 1995) of the NOPACCS NH95-1 cruise (data were 


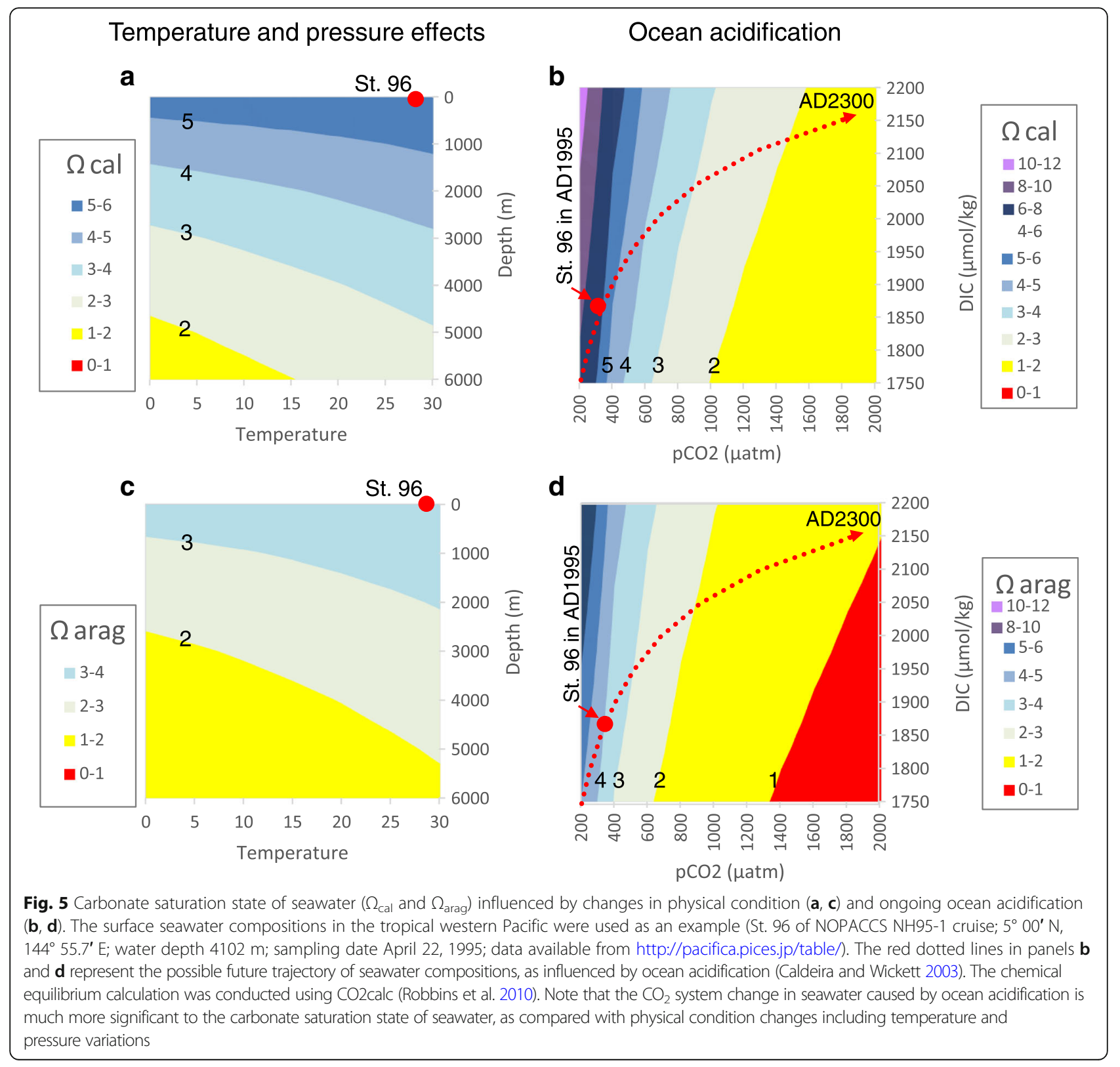

Table 1 Water properties under different environmental conditions. In particular, $\left[\mathrm{CO}_{3}{ }^{2-}\right]$ and the corresponding saturation states of calcite and aragonite $\left(\Omega_{\text {cal }}\right.$ and $\left.\Omega_{\text {arag }}\right)$ are calculated for modern, 2110 AD, and Cretaceous conditions using CO2calc (Robbins et al. 2010). The numbers in the gray color column show the initial settings for the calculation

\begin{tabular}{|l|r|r|r|r|r|r|r|r|r|l|}
\hline Tempearture & $\mathrm{PCO}_{2}$ & Water depth & \multicolumn{1}{c|}{$\mathrm{TA}$} & \multicolumn{1}{c|}{$\mathrm{DIC}$} & \multicolumn{1}{c|}{$\mathrm{pH}$} & \multicolumn{1}{c|}{$\mathrm{CO}_{2}$} & {$\left[\mathrm{CO}_{3}{ }^{-}\right]$} & $\Omega \mathrm{cal}$ & $\Omega \mathrm{arg}$ & \\
\hline \multicolumn{1}{|c}{${ }^{\circ} \mathrm{C}$} & $\mu \mathrm{atm}$ & $\mathrm{m}$ & $\mu \mathrm{mol} / \mathrm{kg}$ & $\mu \mathrm{mol} / \mathrm{kg}$ & Total scale & $\mu$ atm & $\mu \mathrm{mol} / \mathrm{kg}$ & & & \\
\hline $28^{\circ} \mathrm{C}$ & 400 & 1 & 2200 & 1898 & 8.027 & & 210 & 5.13 & 3.41 & Tropical ocean at modern condition \\
\hline $2^{\circ} \mathrm{C}$ & 400 & 1 & 2200 & 2084 & 8.018 & & 89 & 2.14 & 1.34 & Cold ocean at modern conditionn \\
\hline $2^{\circ} \mathrm{C}$ & & 4000 & 2200 & 2084 & 7.857 & 378 & 82 & 0.89 & 0.59 & Only sinking of surface cold water to deep-sea \\
\hline $2^{\circ} \mathrm{C}$ & & 4000 & 2200 & 2459 & 6.806 & 4673 & 8 & 0.09 & 0.06 & Sinking of surface cold water to deep-sea with the contribution of degradation of OM \\
\hline $28^{\circ} \mathrm{C}$ & 800 & 1 & 2200 & 2027 & 7.774 & & 131 & 3.20 & 2.13 & Tropical ocean at 2100AD \\
\hline $2{ }^{\circ} \mathrm{C}$ & 800 & 1 & 2200 & 2169 & 7.739 & & 49 & 1.18 & 0.74 & Tropical ocean at 2100AD \\
\hline $2^{\circ} \mathrm{C}$ & & 4000 & 2200 & 2544 & 6.693 & 6076 & 6 & 0.07 & 0.04 & Sinking of surface cold water to deep-sea with the contribution of degradation of OM \\
\hline $28^{\circ} \mathrm{C}$ & 1600 & 1 & 2200 & 2131 & 7.504 & & 76 & 1.85 & 1.23 & Tropical ocean at 4x PCO2 \\
\hline $17^{\circ} \mathrm{C}$ & 1600 & 1 & 2700 & 2652 & 7.572 & & 74 & 1.78 & 1.15 & High latitude surface water at high TA condition during Cretaceous \\
\hline $17^{\circ} \mathrm{C}$ & & 4000 & 2700 & 2652 & 7.424 & 1536 & 69 & 0.87 & 0.59 & Deep water at high TA condition during Cretaceous \\
\hline
\end{tabular}

Here, we assumed that the pressuere at $1 \mathrm{~km}$ water depth roughly corresponded to $\sim 100 \mathrm{bar}$ (1000 dbar) 
downloaded from http://pacifica.pices.jp/table/), as shown in Fig. 4. The pressure influence becomes dominant at greater depth because $K_{\mathrm{sp}}$ increases 1.72 times from the surface to $4000 \mathrm{~m}$ depth (Fig. 4d, e; Table 1). The corresponding saturation levels of the carbonate ion concentration $\left[\mathrm{CO}_{3}{ }^{2-}\right]_{\text {sat }}$ are $41 \mu \mathrm{mol} \mathrm{kg}{ }^{-1}$ and $70 \mu \mathrm{mol} \mathrm{kg}{ }^{-1}$ at the surface and $4000 \mathrm{~m}$ depth, respectively. Note that the changes in $\mathrm{CO}_{2}$ system chemistry, i.e., degradation of $\mathrm{OM}$ and $\mathrm{pH}$ decrease, are responsible for the rapid decreases in $\Omega_{\text {cal }}$ and $\Omega_{\text {arag }}$ for the depth interval below the surface layer.

Figure 5 illustrates a more quantitative comparison of the factors influencing $\Omega$. The surface water compositions at St. 96 in the western tropical Pacific are again used as an example. Temperature decrease and pressure increase result in decreases in $\Omega_{\text {cal }}$ and $\Omega_{\text {arag }}$ in seawater (Fig. 5a, c), but the condition of undersaturation with respect to aragonite is never reached. On the other hand, the significant changes in $\Omega_{\text {cal }}$ and $\Omega_{\text {arag }}$ can be caused by ongoing and future changes in the marine $\mathrm{CO}_{2}$ system, indicating that $\mathrm{OA}$ is the prime driver of $\Omega$ under the conditions of climate change.

\section{Characteristics of biotic and abiotic-carbonate minerals}

The chemical composition, ultrastructure, and organic components of carbonate minerals ultimately determine their physical and chemical properties. An apparent difference in mineral solubility exists between the two major polymorphs of calcium carbonate, i.e., calcite and aragonite (Morse et al. 2007; Ries 2011a, b). Calcite has the lower solubility with a stoichiometric solubility product in seawater $K^{\prime}{ }_{\text {sp(stoich) }}$ of 6.65 , whereas aragonite is more soluble $\left(K_{\text {sp(stoich })}^{\prime}=4.29\right.$, Morse et al. 1980). The solubility of calcite increases with increasing $\mathrm{Mg}$ content. The solubility of calcite, with an $\mathrm{Mg} / \mathrm{Ca}$ of 0.14 , is calculated to be equivalent to that of aragonite (Ries 2011b).

The physical properties of biominerals outperform abiotic minerals with respect to toughness, hardness, multi-scale ordering, and architecture (e.g., Ma et al. 2009). In order to facilitate calcification, biogenic calcium carbonate has the compositional and spatial complexity of inorganic and organic compounds (Tamenori et al. 2014). One example is $\mathrm{Mg}$, an important minor constituent element in the hexagonal calcite structure (Finch and Allison 2008; Branson et al. 2013; Yoshimura et al. 2015), which affects polymorph mineralogy, the rate of crystal growth, and the solubility of calcium carbonate (Davis et al. 2000; De Groot and Duyvis 1966). The skeletons produced by anatomically simple organisms such as corals, macrophytic algae, sponges, and bryozoans are composed of a high-Mg calcite containing $>4 \mathrm{~mol} \% \mathrm{MgCO}_{3}$ in solid solution. In the modern marine environment, high-Mg calcite and aragonite form via abiotic reactions. Because the presence of $\mathrm{Mg}^{2}$ ${ }^{+}$in a fluid is known to inhibit calcite crystal growth (Davis et al. 2000; Mucci and Morse 1983), certain taxa such as foraminifera, coccolithophores, mollusks, and brachiopods with skeletons composed of low-Mg calcite $(\mathrm{Mg} / \mathrm{Ca}$ molar ratio is below $4 \mathrm{~mol} \%)$ reduce the $\mathrm{Mg} /$ $\mathrm{Ca}$ ratio in the calcifying solution, and their skeletons are generally more resistant to OA.

In the pelagic ocean, up to $80 \%$ of the biogenic carbonate is remineralized in the upper water column (Millero 2007). After the remaining portion settles through the water column, the oxidation of $\mathrm{OM}$ at the sediment-water interface plays a major role in diagenetic dissolution processes (Eqs. 2 and 4 in Fig. 1). As described in the following sections, the formation and dissolution of carbonates in the context of $\mathrm{CO}_{2}$-induced $\mathrm{OA}$ are examined in terms of $\Omega$ for a given environment. Although differences in the extent of carbonate dissolution in the ocean basins are primarily controlled by seawater $p \mathrm{CO}_{2}$, the use of simple thermodynamic relationships in seawater systems is not always an accurate predictor of biogenic carbonate dissolution due to the complex interplay of mineral surfaces and microbial processes, the presence of reaction inhibitors, the heterogeneity of trace element distribution, differences in the susceptibility of skeletal ultrastructure, and so on (Morse et al. 2007; Cusack and Freer 2008; Iwasaki et al. 2015; Yoshimura et al. 2017). For example, the impact of preferential dissolution is seen in a size-dependent change of the mass fluxes of foraminifera, along with water depth and their relevance to total carbonate flux (Thunell et al. 1983).

\section{Ocean acidification under increased $p \mathrm{CO}_{2}$ conditions in the atmosphere}

Anthropogenic $\mathrm{CO}_{2}$-driven $\mathrm{OA}$ has been reported to pose a severe threat to marine calcifying organisms because the calcification rates of organisms generally decrease in acidified seawater (e.g., Gattuso et al. 1999; Iguchi et al. 2012, 2014; reviewed in Kleypas et al. 2006; Kroeker et al. 2013). Kroeker et al. (2010) conducted a meta-analysis of 149 results (including 18 coral, 1 large-benthic foraminifera, and 15 coccolithophorid studies) and reported generally negative effects on survival, calcification, growth, and reproduction, despite significant variations among taxonomic groups.

\section{General features of the response of coral to ocean acidification}

The work of Kleypas et al. (1999) is widely recognized as one of the pioneering studies focusing on the decrease of coral calcification under the influence of increased atmospheric $p \mathrm{CO}_{2}$, although the term "ocean acidification" was not used in this paper. Since then, experimental studies on calcification versus $\Omega_{\text {arag }}$ at the level of marine organisms and communities have become more prevalent (Orr et al. 2005). In a recent review, the majority of corals were identified as showing a negative 
response to a decrease in aragonite saturation (Wittmann and Pörtner 2013).

Although some decreases in calcification rates in acidified seawater have been observed among coral species (Ries et al. 2009; Comeau et al. 2014; Iguchi et al. 2014; Sekizawa et al. 2017), some species are insensitive to acidified seawater under certain conditions (e.g., Holcomb et al. 2010; Rodolfo-Metalpa et al. 2010; Chauvin et al. 2011; Ohki et al. 2013; Takahashi and Kurihara 2013; Nakamura et al. 2017). It is suggested that increased $p \mathrm{CO}_{2}$ may facilitate the onset of photosynthesis by increasing $\mathrm{HCO}_{3}{ }^{-}$levels in acidified seawater (Marubini et al. 2008; Comeau et al. 2013). Although the relationship between coral calcification and photosynthesis by symbiotic algae in acidified seawater is not straightforward (Kleypas et al. 2006; Tanaka et al. 2007), it is evident that increased $\mathrm{HCO}_{3}{ }^{-}$in acidified seawater partially facilitates coral calcification (Marubini et al. 2008; Comeau et al. 2013).

The impact of OA on corals has also been studied at the ecosystem level. Kleypas and Langdon (2006) reported that a $\Omega_{\mathrm{arag}}$ of 3.3 is likely the environmental limit for the existence of tropical coral reefs where calcification exceeds the dissolution of calcium carbonate. Hoegh-Guldberg et al. (2007) discussed possible future coral reef scenarios under rapid climate change and OA and concluded that a $p \mathrm{CO}_{2}$ above $500 \mathrm{ppm}$ presented a high risk to coral reefs, with a potential for the loss of coral-dominated ecosystems. Recently, Cyronak et al. (2018) proposed a biogeochemical approach based on DIC-TA plots to monitor the net calcification potential of coral reef ecosystems under anthropogenic perturbations including ocean warming and acidification.

A poleward shift of the northern limit of coral distribution along the Japanese Islands has been reported and attributed to global warming (Yamano et al. 2011). However, OA in temperate waters may influence a northward shift of coral distribution.

\section{Response of foraminifera to ocean acidification}

Recent foraminiferal studies (both planktic and benthic) generally exhibited negative responses to OA (e.g., Russell et al. 2004; Kuroyanagi et al. 2009; Kroeker et al. 2010; Keul et al. 2013). Culturing results showed that shell calcification decreased under low $\left[\mathrm{CO}_{3}{ }^{2-}\right]$. For example, culture experiments suggested that the higher is $\left[\mathrm{CO}_{3}{ }^{2-}\right]$, the heavier is the shell produced by planktic foraminifera (Orbulina universa) (Bijma et al. 1999). Moreover, the shell weight of Globigerinoides sacculifer increases $2.1-3.6 \mu \mathrm{g}$ for every $100 \mu \mathrm{mol} \mathrm{kg}^{-1}$ increase in $\left[\mathrm{CO}_{3}{ }^{2-}\right]$ (Bijma et al. 2002). Although this effect on shell production would be species-specific, the shell weight and calcification rate of both O. universa and G. sacculifer have been shown to exhibit increases under high $\left[\mathrm{CO}_{3}{ }^{2-}\right]$ (Lombard et al. 2010). Keul et al. (2013) also cultured benthic foraminifera (Ammonia sp.) under constant DIC concentrations or constant $\mathrm{pH}$ conditions and reported that increased $\left[\mathrm{CO}_{3}{ }^{2-}\right]$ caused increasing size-normalized shell weights and growth rates.

Some culturing results have suggested a new perspective on acidification. When we attempt to evaluate the effect of OA on foraminifera, we have to consider (1) that the biological responses to OA differ among different life stages (i.e., gamete, neanic, or mature) and (2) the effect of each carbonate species (i.e., $\left[\mathrm{CO}_{3}{ }^{2-}\right],\left[\mathrm{HCO}_{3}{ }^{-}\right]$, and $\left[\mathrm{CO}_{2}\right]$ ) on shell calcification. Kroeker et al. (2010) reported that the larval and juvenile phases of marine organisms might be more vulnerable to OA. In fact, cultured juvenile Neogloboquadrina pachyderma (sin.) individuals were more affected by reductions in $\mathrm{pH}$ than adults (Manno et al. 2012).

Other culturing experimental studies using asexually reproduced individuals have revealed different trends among genera. Hikami et al. (2011) observed opposite responses among two reef-dwelling (large-benthic) foraminifera under different $p \mathrm{CO}_{2}$ culturing conditions, which may have been due to the different symbiotic algae and/or biological-calcification system. The shell weights of two foraminifera, Amphisorus and Calcarina, were controlled mainly by $\left[\mathrm{CO}_{3}{ }^{2-}\right]$ and $p \mathrm{CO}_{2}$, respectively (Fig. 6).

Several studies have suggested size-normalized planktic foraminiferal shell-weight as a proxy for ambient seawater $\left[\mathrm{CO}_{3}{ }^{2-}\right]$ (e.g., Barker and Elderfield 2002; Bassinot et al. 2004; Naik et al. 2010). Moy et al. (2009) compared the shell weights of planktic foraminifera (Globigerina bulloides) from sediment trap samples (i.e., modern day) with those in Holocene-age sediments. The modern-day shell weights were $30-35 \%$ lower than those of the Holocene-age sediments in the Southern Ocean. In addition, the fossil shell weight of this species (G. bulloides) tracks the Vostok $p \mathrm{CO}_{2}$ record over the last 50 kyr (e.g., Barker and Elderfield 2002; Moy et al. 2009). However, at the same pressure-normalized $\left[\mathrm{CO}_{3}{ }^{2-}\right.$, Pulleniatina obliquiloculata from the Pacific were consistently $10 \mu \mathrm{g}$ heavier than those from the Indian Ocean (Broecker and Clark 2001). de Villiers (2003, 2004) suggested that $\Omega$ is not the only factor controlling the shell weight of several planktic species, and Marr et al. (2011) suggested that temperature is a prominent control on G. bulloides shell weight (negative correlation). GonzalezMora et al. (2008) proposed both water temperature and $p \mathrm{CO}_{2}$ as the main controlling factors on shell calcification. This was based upon the observation that G. bulloides shell weight followed the opposite trend to $\mathrm{Mg} / \mathrm{Ca}$ paleothermometry and Vostok $p \mathrm{CO}_{2}$ during 250-160 kyr in the Western Mediterranean. However, they also reported that the shell weight of N. pachyderma (dex.) was not related to either parameter, but their optimum growth condition,

Since temperature controls $\mathrm{CO}_{2}$ solubility (i.e., $p \mathrm{CO}_{2}$ and $\left.\left[\mathrm{CO}_{3}{ }^{2-}\right]\right)$ in seawater, both $\left[\mathrm{CO}_{3}{ }^{2-}\right]$ and temperature 


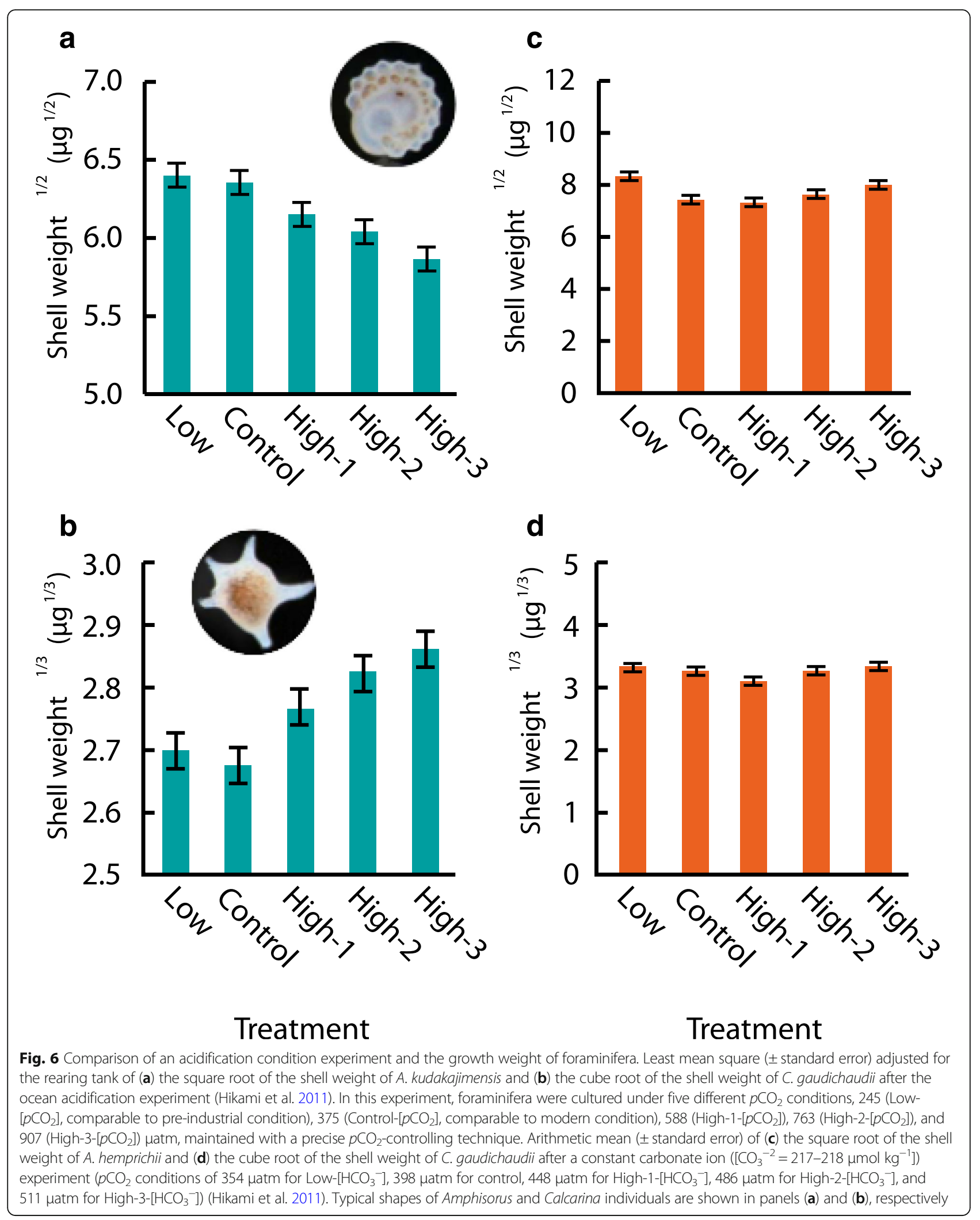


affect size-normalized foraminiferal shell weight. Therefore, further work on these two parameters should be carried out to confirm the effect on foraminiferal calcification.

\section{Bleaching of corals and foraminifera in a warm and/or high $\mathrm{CO}_{2}$ world}

Major planktic foraminifera in the tropical/subtropical ocean, such as G. sacculifer, Globigerinoides ruber, and Globigerinella siphonifera, bear photosynthetic symbiotic algae such as dinoflagellates and chrysophycophyte (Schiebel and Hemleben 2017). Large benthic foraminifera, dwelling in warm shallow coral reefs, harbor several microalgae of dinoflagellates, diatoms, red algae, and others as symbionts (Lee and Anderson 1991). Many scleractinian corals that inhabit tropical/subtropical oceans belong to the class Anthozoa of the phylum Cnidaria. They typically live in compact sessile colonies of small individual animals (polyps) that produce hard skeleton structures of aragonite; these are important reef builders. They maintain a symbiotic relationship with photosynthetic dinoflagellate. However, young polyps are not born with dinoflagellate; rather, they obtain algae from the surrounding water column and local sediment.

Bleaching is a potentially global threat to marine symbiotic calcifying organisms, especially corals and foraminifera. When stress-caused bleaching is not severe, both have been known to recover. However, if the algae loss is prolonged and the stress continued, both will eventually disappear.

\section{Coral bleaching}

Role of symbiosis in corals An important aspect in relation to the response of coral calcification to environmental changes is the existence of photosynthetic symbiotic dinoflagellates, zooxanthellae (genus Symbiodinium). An association between reef-building corals and their symbiotic algae is essential for coral survival in nature (Yellowlees et al. 2008). In addition, coral calcification is facilitated by the photosynthesis of symbiotic algae (Gattuso et al. 1999). Therefore, it is necessary to consider the existence of symbiotic algae when we evaluate the effects of environmental changes on coral calcification. Coral calcification is closely related to coral growth, which is an essential characteristic of their life history; thus, a decrease in coral calcification would lead to negative impacts by causing difficulties in maintaining coral life histories. In relation to the responses of corals to environmental changes, the most significant phenomenon is coral bleaching (e.g., De'ath et al. 2009) (Fig. 7).

Bleaching due to the collapse of coral-algal symbiosis The effect of seawater temperature on corals has been well studied because high seawater temperature is known to be a main factor causing the collapse of coralalgal symbiosis, which is followed by coral death (reviewed in Hoegh-Guldberg 1999). As to the cause of coral bleaching, it is suggested that higher temperature induces oxidative stress in corals. In regards to coral calcification, the increase in seawater temperature facilitates calcification within a range of mild temperatures

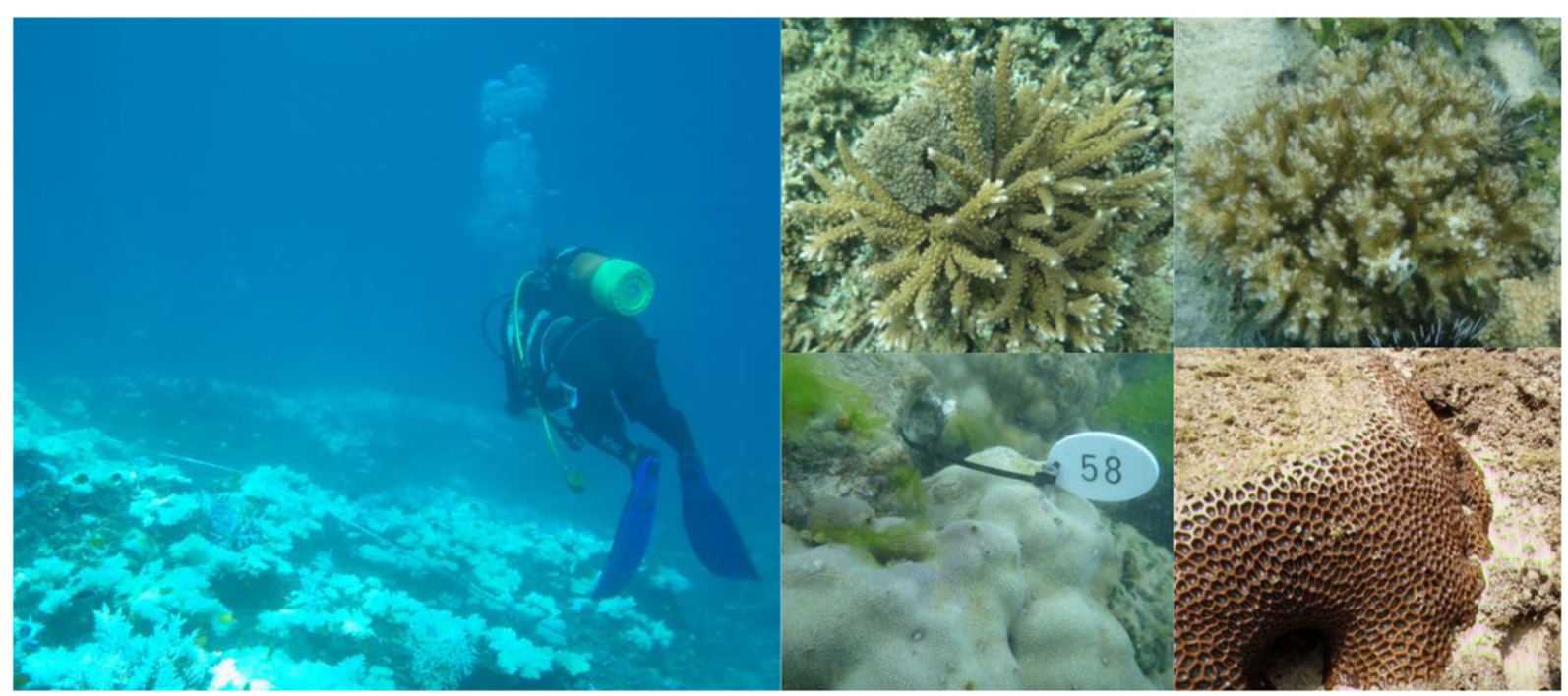

Fig. 7 Left panel shows coral bleaching occurring in the Sekisei Reef $\left(24^{\circ} \mathrm{N}, 124^{\circ} \mathrm{E}\right)$, Japan, in September, 2016. Although many coral species are affected by high temperature, it is known that massive or encrusting corals tend to survive even in mass bleaching events. The top of the right panel shows thermal stress sensitive species (Acropora and Pocillopora; losers) and the bottom shows stress tolerant species (Porites and Favites; winners) 
(Inoue et al. 2012). Based on the observation of skeletal oxygen isotope $\left(\delta^{18} \mathrm{O}\right)$ and carbon isotope $\left(\delta^{13} \mathrm{C}\right)$ microprofiles in coral cores, Suzuki et al. (2003) reported that severe coral bleaching inhibited coral calcification of a massive Porites colony in 1998. Also based on coral cores, De'ath et al. (2009) suggested that increased temperature stresses suppressed the coral calcification of massive Porites on the Great Barrier Reef, although it is thought that other environmental factors were likely related to the suppression. Using coral cores of Diploastrea heliopore, Cantin et al. (2010) reported that increased seawater temperature decreased coral growth.

Laboratory rearing experiments have also clarified variations in the calcification patterns of corals in certain temperature regimes (Anthony et al. 2008; Inoue et al. 2012). For example, Nishida et al. (2014a) reared coral nubbins of an encrusting coral, Isopora palifera, under various temperature treatments and found that calcification was suppressed in higher temperature treatments $\left(>31{ }^{\circ} \mathrm{C}\right.$ ). It is known that there are variations in sensitivity to heat stress among species (namely, the winners and the losers in coral bleaching; Loya et al. 2001; van Woesik et al. 2011). Morphological (e.g., branched, flat; Loya et al. 2001) and/or physiological variations (e.g., symbiont type, energy availability; Baird et al. 2009) among species would contribute to different susceptibilities to heat stress. However, studies on calcification responses to seawater temperature among species remain limited.

Culture experiment using aposymbiotic polyps The difficulty in understanding the complicated responses of coral calcification is partly attributed to the fact that coral calcification is closely related to coral-algal symbiosis, which forces us to consider both the coral host and the symbiotic algae. Thus, separating the coral host and symbiotic algae under experimental conditions would be helpful to better understand the responses of coral calcification to environmental changes. Acropora species release their gametes into seawater in a mass spawning event in early summer. The eggs do not include symbiotic algae but Acropora species incorporate symbiotic algae mainly after their settlement. Thus, if we culture coral planulae and induce their settlement under artificial conditions using filtered seawater, which does not contain symbiotic algae, we can easily produce aposymbiotic polyps.

Furthermore, we can also induce the infection of symbiotic algae for aposymbiotic polyps by adding symbiotic algae using an artificial method. Thus, this coral primary polyp system enables us to experimentally separate the association of symbiotic algae from their coral host and also allows us to determine which stage of the calcification process is sensitive to environmental changes (Inoue et al. 2012; Tanaka et al. 2013, 2014; Nishida et al. 2014b). Using this system, we attempted to evaluate how seawater temperature and acidification affect coral calcification from the perspective of both the coral host and the symbiotic algae. In the case of the calcification responses to temperature, the responses were clearly different between aposymbiotic and symbiotic polyps. The peak of calcification in symbiotic polyps was around $29{ }^{\circ} \mathrm{C}$ while that in aposymbiotic polyps was around $31{ }^{\circ} \mathrm{C}$. Considering the fact that the calcification of aposymbiotic polyps increased at $31{ }^{\circ} \mathrm{C}$, the tolerance of the coral host to thermal stress seems to be higher, as compared with the symbiotic condition. In the case of calcification responses to seawater acidification, calcification tended to decrease according to the increase of $p \mathrm{CO}_{2}$ in both aposymbiotic and symbiotic polyps; however, the calcification of adult branches was not decreased at higher $p \mathrm{CO}_{2}$ conditions (Ohki et al. 2013). The fertilization effect of increased $p \mathrm{CO}_{2}$ on coral calcification may differ across life stages.

In addition to the advantage described above, the coral primary polyp system has certain further advantages for evaluating the calcification responses of corals, as compared with experiments using the adult branches of corals. Primary polyps are very small and the calcification of primary polyps is visibly fast; therefore, a sufficient number of specimens is easily available. As such, the application of live tissue imaging to the coral primary polyp system would facilitate our understanding of the calcification responses of corals to various environmental factors (Ohno et al. 2017a, b).

\section{Foraminiferal bleaching}

Bleaching in algal symbiont-bearing large benthic foraminifera Bleaching in algal symbiont-bearing, large benthic foraminifera was first observed in laboratory experiments in Amphistegina spp. in the early 1980s, and it was first noted in 1988 in field populations of Amphistegina gibbosa in the Florida Keys. Since 1991, bleaching in Amphistegina populations has been observed in subtropical reefs worldwide (Hallock et al. 2006). Bleaching in Amphistegina appears as partial "mottling" (small white spots) that is uniformly pale or extensively white (Hallock et al. 2006). Cytological studies indicate that bleaching in Amphistegina is caused by the loss of photosynthetic microalgae and/or their photopigments; it is due to the digestion of deteriorating symbionts by the host (Talge and Hallock 2003). Experimental studies suggest that bleaching in Amphistegina is induced by photoinhibitory stress, in particular by the shorter $(300-490 \mathrm{~nm})$ wavelengths of solar radiation (Williams and Hallock 2004).

Temperature stress is also related to foraminiferal bleaching. In culture experiments, Talge and Hallock (2003) found that bleaching in Amphistegina occurred more intensively when incubated at $32{ }^{\circ} \mathrm{C}$ than at $25{ }^{\circ} \mathrm{C}$, indicating that bleaching was enhanced by elevated 
temperature with photic stress. Later, Schmidt et al. (2011) demonstrated bleaching (the loss of photopigments) and decreased photosynthetic efficiency in other diatom symbiont-bearing foraminiferal species (Amphistegina radiata, Heterostegina depressa, and Calcarina hispida) under high temperature stress $\left(>30{ }^{\circ} \mathrm{C}\right)$. Subsequent similar experimental studies confirmed bleaching and reduced photosynthetic efficiency in many other symbiont-bearing foraminiferal species under high temperature stress (e.g., van Dam et al. 2012; Fujita et al. 2014; Schmidt et al. 2014). As summarized in Sheppard et al. (2009), bleaching at elevated temperature is related to the photoinhibition of algal symbionts. Temperature limits the rate of electron transport in photosystems and the turnover of associated D1 proteins. As a result, the rate of excitation (light capture by reaction centers) exceeds the rate of light utilization (photochemistry). This excess energy results in a buildup of reactive oxygen species (ROS). The overproduction of ROS causes damage to the photosynthetic apparatus of symbionts as well as to host cells.

A meta-analysis of available experimental data up to the year 2014 (Doo et al. 2014) showed a negative trend between growth and photosymbiont health under $\mathrm{a}+4{ }^{\circ} \mathrm{C}$ warming scenario, as compared with the present-day condition (Fig. 8). Host foraminifera became inactive, grew slowly, and tended to have increased mortality (Fig. 8a). Algal endosymbionts, irrespective of symbiont type, exhibited (i) decreased concentrations of chlorophylls and other photopigments, (ii) a decline in the maximum quantum yields of Photosystem II (PSII; Fv/Fm) and other photophysiological parameters, (iii) reduced numbers of viable symbionts and high numbers of deteriorating symbionts, and (iv) decreased levels of RuBisCO protein (the enzyme responsible for fixing $\mathrm{CO}_{2}$ ).

Responses of symbiont-bearing benthic foraminifera in a warm and/or high $\mathrm{CO}_{2}$ world Foraminiferal-algal associations (as holobionts) exhibited bleaching, decreased net $\mathrm{O}_{2}$ production rates, increased respiration rates, decreased organic carbon $(\mathrm{C})$ and nitrogen $(\mathrm{N})$ contents, and decreased molar $\mathrm{C} / \mathrm{N}$ ratios (summarized in Fujita et al. 2014). This negative trend in foraminiferal responses is supported by culturing experimental studies conducted after that of Doo et al. (2014) (e.g., Sinutok et al. 2014; Prazeres et al. 2016; Schmidt et al. 2016). These experimental studies suggest that combined temperature and light stresses induce the inactivation of photosystems, bleaching, and reduced energy storage. This damage to algal symbionts results in a lack of

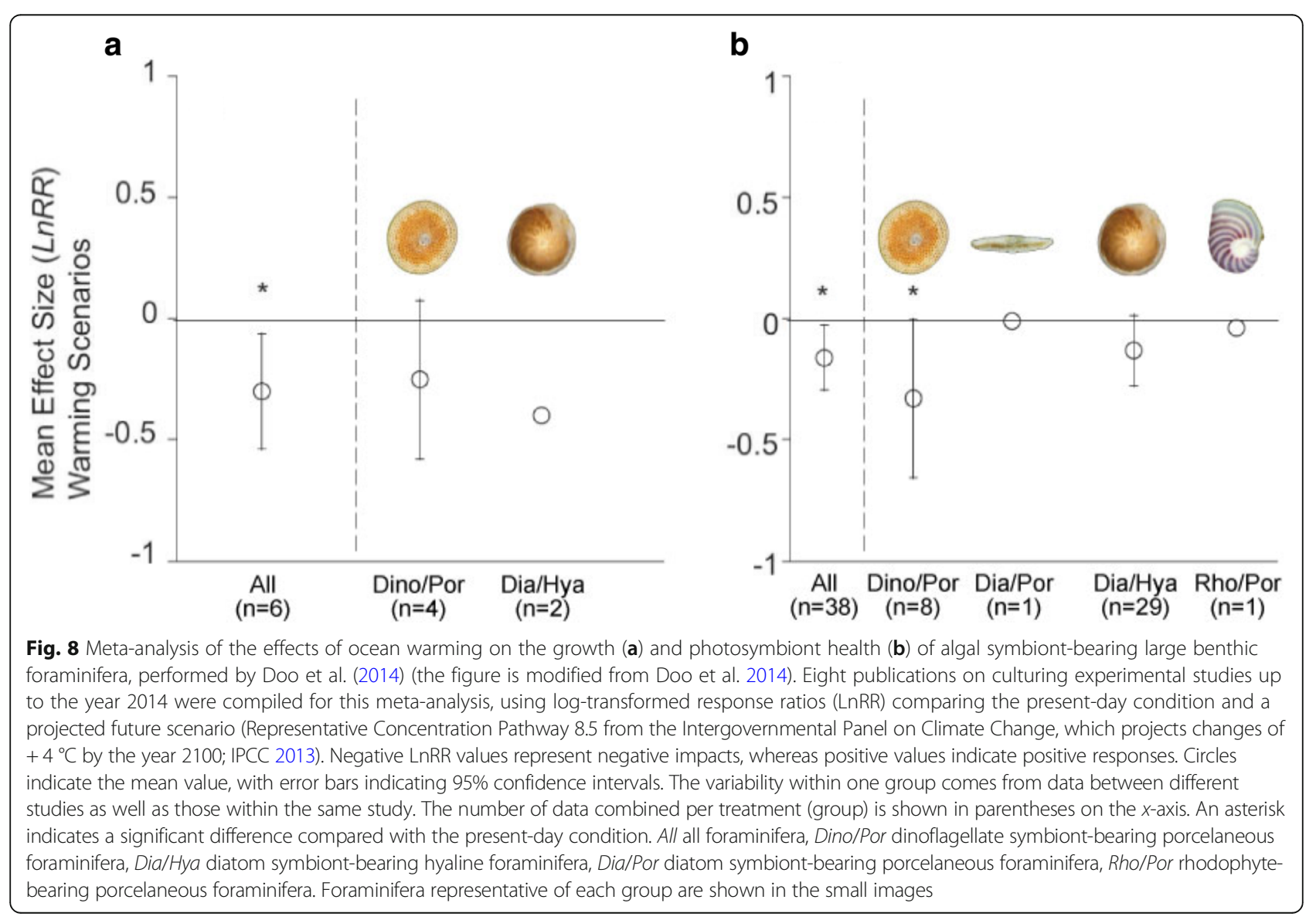


movement, reduced growth, changes in symbiont genotypes, increased susceptibility to bacterial/algal infection, disease, and finally death of the host foraminifera. Thus, bleaching and associated photophysiological parameters in algal symbiont-bearing foraminifera would be useful as a sensitive bio-indicator of ocean warming.

Results of the meta-analysis also imply that diatom symbionts appear more resilient than dinoflagellate symbionts under ocean warming (Fig. 8b). A meta-analysis for OA scenarios also suggests that hyaline taxa with diatom symbionts appear more resilient than porcelaneous taxa with dinoflagellate symbionts (Doo et al. 2014). These contrasting differences in host growth and photosymbiont health between two foraminiferal taxa with different algal symbionts will likely result in the dominance of hyaline foraminifera over porcelaneous foraminifera in symbiont-bearing reef foraminiferal communities in the future, as well as the geographical expansion of the former taxa to higher latitudes (Weinmann et al. 2013). The resilience of diatom symbionts over dinoflagellate symbionts under ocean warming may also partially explain the dominance of large benthic foraminifera during the warm period of the Cenozoic. During the Paleogene, hyaline rotaliid taxa such as Nummulites dominated and diversified in tropical to subtropical carbonate environments (Hallock 2000). Based on the fact that their modern descendants host diatom symbionts, these extinct hyaline taxa possibly harbor diatom symbionts (Lee 1998). Thus, a warm, high $\mathrm{CO}_{2}$ world in the geological past was likely favored by hyaline taxa with diatom symbionts but not by porcelaneous taxa with dinoflagellate symbionts, as suggested by Hallock (2000) and Fujita et al. (2011).

\section{Biomineralization in corals and foraminifera}

In order to estimate future response of corals and foraminifera to $\mathrm{OA}$, it is important to understand the basic mechanism of small-scale calcification.

\section{Biomineralization of corals}

Hypotheses for the mechanism of coral biomineralization Screlactinian corals are important in terms of marine biodiversity and the reconstruction of climate change in the past. Since the acidification of seawater affects coral skeletons through physiological coral activities, culture experiments using screlactinian corals under acidified seawater have been conducted. In particular, as substantial recruitment is critical for the persistence of coral reef ecosystems (Hughes and Tanner 2000) and primary polyps of coral are highly susceptible to the potential effects of OA (Kurihara 2008; Suwa et al. 2010), investigations on the growth of the primary polyp skeleton have been conducted (Albright et al. 2008; Inoue et al. 2011; Ohki et al. 2013). Before discussing the influence of OA, we present the latest hypothetical models to make the process of biomineralization easily understandable.

Hohn and Merico $(2012,2015)$ classified the many proposed ideas into four different hypotheses that reflect alternative realizations of ion transport in corals (Fig. 9). Hypothesis 1 (H1) states that only transcellular ion transport of $\mathrm{Ca}^{2+}$ and $\mathrm{HCO}_{3}{ }^{-}$into the calcifying fluid induces coral calcification (Allemand et al. 2004) (Fig. 9a). Hypothesis $2(\mathrm{H} 2)$ proposes that $\mathrm{Ca}^{2+}$ and carbon are supplied only by the paracellular pathway (Gagnon et al. 2012). In hypothesis 3 (H3), protons are removed from the calcifying fluid to increase aragonite saturation by a proton pump while $\mathrm{Ca}^{2+}$ is transported into the calcifying fluid passively via the paracellular pathway, known as the proton flux hypothesis (Jokiel 2011; Ries 2011a). In hypothesis $4(\mathrm{H} 4)$, a combination of transcellular and paracellular ion transport can induce coral calcification (Cohen and McConnaughey 2003; Nakamura et al. 2017). Hohn and Merico (2015) examined the plausibility of different calcification mechanisms in relation to OA using a mathematical model. The results suggest that $\mathrm{H} 4$ and a combination of the processes in $\mathrm{H} 1$ and $\mathrm{H} 2$ are consistent with changes in calcifying fluid $\mathrm{pH}$

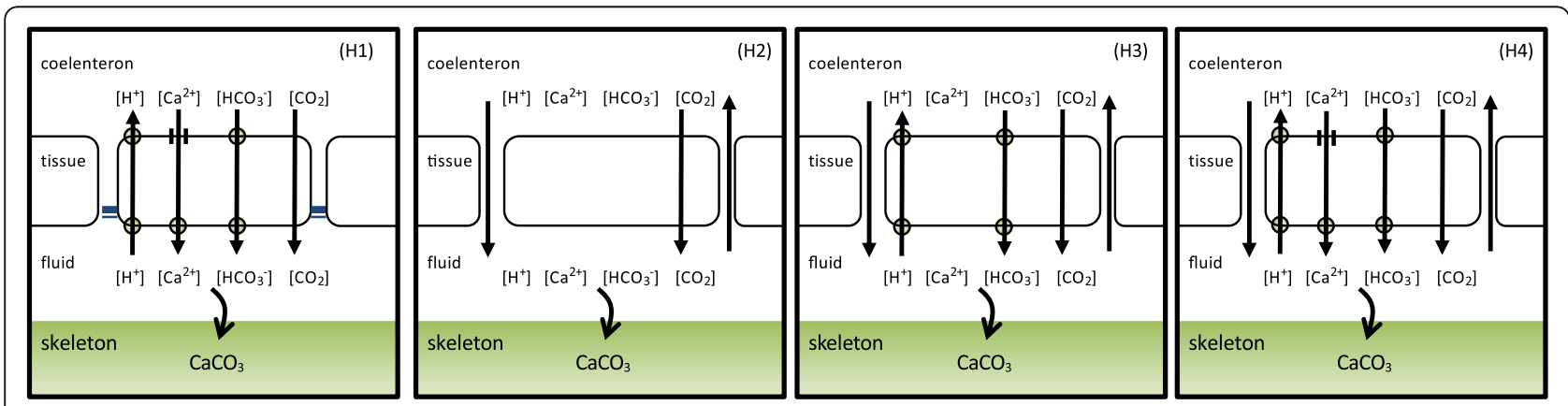

Fig. 9 Different ion transport hypotheses tested in this study and their simulation results (Hohn and Merico 2015). (H1) transcellular ion transport only, ( $\mathrm{H} 2)$ paracellular ion transport only, $(\mathrm{H} 3)$ proton flux hypothesis, and $(\mathrm{H} 4)$ combination of transcellular and paracellular ion transport. The upper panels visualize the conceptual models of the different transport hypotheses $(\mathrm{H} 1-\mathrm{H} 4)$. Ca ${ }^{2+}$ is transported into the cell through the Ca ${ }^{2}$ ${ }^{+}$-channel, whereas it is transported into the calcifying fluid from the cell by the Ca-ATPase pump 
and $\mathrm{Ca}$ concentration and with calcein staining experiments. An efflux of $\mathrm{Ca}^{2+}$ and $\mathrm{CO}_{3}{ }^{2-}$ from the calcifying fluid is generated by the paracellular pathway, which results in a leakage of ions that counteracts the concentration gradients maintained by the transcellular pathway. Future ocean acidity would exacerbate this carbonate leakage and reduce the ability of corals to accrete $\mathrm{CaCO}_{3}$. However, this result was obtained by computer simulation and was not confirmed by observations in field and culture experiments. Ca isotopic work could provide some clarification on this issue.

Biomineralization of corals based on analyses of Ca isotopes It has been suggested that acidified seawater significantly decreases the growth rate of primary polyps, as reported for adult corals. However, recent studies suggest that corals regulate their internal $\mathrm{pH}$ and then counteract any acidification (Ohno et al. 2017a; McCulloch et al. 2012). In fact, the mechanism by which corals control the transport of $\mathrm{Ca}^{2+}$ and other ions from seawater are largely unknown. Corals build their skeletons using extracellular calcifying fluid located at the tissueskeleton interface.

In terms of coral calcification, $\mathrm{Ca}^{2+}$ and $\mathrm{CO}_{3}{ }^{2-}$ must be constantly supplied to the calcifying fluid to precipitate aragonite skeletons. It has been suggested that Ca-ATPase controls the saturation state of aragonite in the calcifying fluid as the pump transfers $\mathrm{Ca}^{2+}$ in exchange for $\mathrm{H}^{+}$across the calicoblastic cells leading to high calcification rates in the calcifying fluid (Fig. 9; Al-Horani et al. 2003; Cohen and McConnaughey 2003). Although there is no transporter known for carbonate, carbon can cross the coral cells via free diffusion of $\mathrm{CO}_{2}$ over cell membranes. Then, the $\mathrm{CO}_{3}{ }^{2-}$ ion can be resupplied because once $\mathrm{CO}_{2}$ or $\mathrm{HCO}_{3}{ }^{-}$reaches the calcifying fluid, a new chemical equilibrium between $\mathrm{CO}_{2}, \mathrm{HCO}_{3}^{-}$, and $\mathrm{CO}_{3}{ }^{2-}$ is established. These pathways are called transcellular pathways since $\mathrm{Ca}^{2+}$ and carbon must pass through the coral cells. However, there are several reports suggesting that seawater may also enter the calcifying fluid directly, mainly based on experiments using a membrane impermeable dye (Cuif et al. 2011; Gagnon et al. 2012).

In order to estimate the transport of $\mathrm{Ca}^{2+}$ by the Ca-channel and Ca-ATPase, Ca isotopes $\left({ }^{44} \mathrm{Ca} /{ }^{40} \mathrm{Ca}\right)$ in screlactinian corals (Acropora sp. and Porites australiensis) have been measured and $+0.4 \%$ offset compared to inorganic aragonite was found (Böhm et al. 2006; Inoue et al. 2015) (Fig. 10). The offset suggests that $\mathrm{Ca}^{2+}$ is transported into calcifying fluid mainly via a transcellular pathway (Fig. 10), although this does not imply that there is no direct transport (paracellular pathway) of other ions from seawater to the calcification site. As mentioned previously, the relative contribution of ion transport (transcellular or paracellular pathways) to coral calcification has been estimated (Hohn and Merico 2015), indicating the importance of transcellular transport, which is always directed into the calcifying fluid. However, there also exists carbonate leakage, which appears to yield greater difficulty in accreting calcium carbonate.

Inoue et al. (2015) further investigated the relationship between the isotope fractionation of $\mathrm{Ca}$ in coral skeletons and the environment (temperature, seawater $\mathrm{pH}$, and light intensity) using cultured corals. As a result, only temperature affected $\delta^{44} \mathrm{Ca}$ in Porites corals and its temperature dependence was $0.02 \% /{ }^{\circ} \mathrm{C}$. Interestingly, negligible changes in isotopic fractionations of $\mathrm{Ca}$ were found in the $\mathrm{pH}$ and light intensity experiments, whereas significant differences in skeletal growth rate were observed in both experiments. Therefore, the transport path of $\mathrm{Ca}^{2+}$ and its activity might have a minor impact on skeletal growth; instead, carbonate chemistry in the fluid would predominantly control the precipitation rate, as suggested by Hohn and Merico (2015) (Fig. 9).

\section{Biomineralization of foraminifera}

Porcelaneous imperforate and hyaline perforate tests of foraminifera Foraminiferal regulation of $\mathrm{Ca}^{2+}$ and $\mathrm{CO}_{3}{ }^{2-}$ uptake into calcareous tests are of great interest to scientists studying $\mathrm{OA}$ and its history. The calcareous foraminifera consist of two groups, porcelaneous (miliolid) and hyaline, according to their test structure. Porcelaneous species produce calcite in the form of needles with a length of a few $\mu \mathrm{m}$ in cellular vesicles (Parker 2017). The walls of these species exhibit an opaque appearance like porcelain. Hyaline species precipitate chamber walls extracellularly on primary organic sheets. These are constructed prior to calcification as a new chamber that provides nucleation sites for the initial calcite precipitation (as reviewed by Erez 2003). The crystallography of the porcelaneous and hyaline species differs from each other, as do their calcification pathways. The porcelaneous species have high Mg-calcite (Toyofuku et al. 2000; Maeda et al. 2017), whereas most hyaline species produce low Mg-calcite. The variability in Mg level can be explained by differences in the cytological pathway of Ca uptake (de Nooijer et al. 2009a). Porceallaneous species form imperforate shells, whereas hyaline species form perforate shells (Ottway et al. 2018).

Since their solubility differs depending on crystallography, the responses of porcelaneous and hyaline species to OA differ markedly. As a result of culture experiments with large foraminifera, the tests porcelaneous species were dwarfed, whereas hyaline species showed no uniform response among the species (Kuroyanagi et al. 2009; Fujita et al. 2011; Hikami et al. 2011). Among recent foraminifera, Hoeglundina and Ceratobulimina 


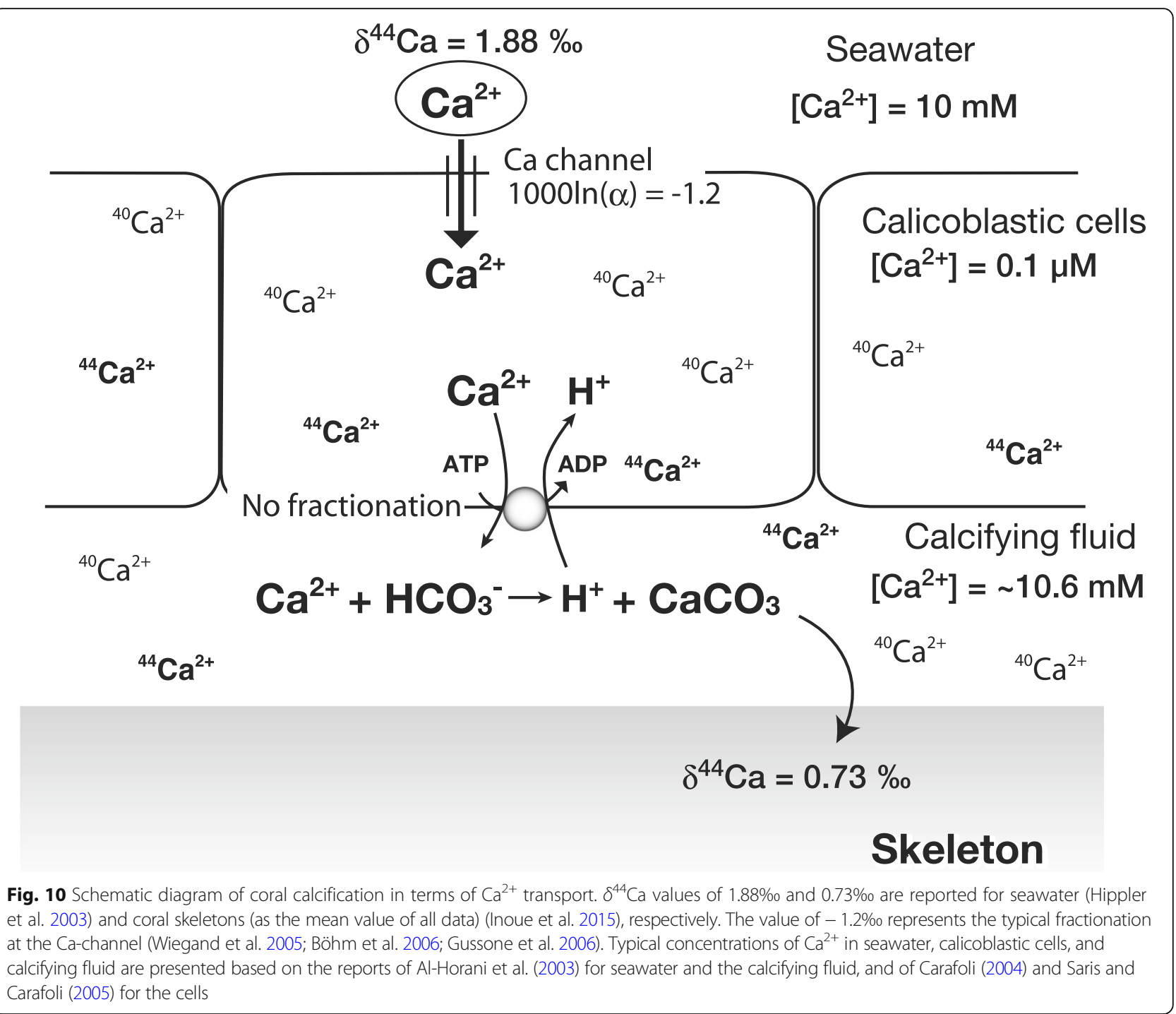

are known to have aragonitic tests (Bandy 1954). Since aragonite has greater solubility than calcite, it is presumed to be strongly affected by acidification; however, there are apparently no studies to confirm this hypothesis. Evaluation of the influence of OA on these aragonitic species is a future research need.

Visualization of extracellular $\mathrm{pH}$ distribution to understand foraminiferal calcification Based on isotope labeling experiments, calcification by foraminifera is hypothesized to involve intracellular storage of $\mathrm{Ca}^{2+}$ ions and inorganic carbon (ter Kuile et al. 1989; Erez 2003). Foraminifera are also considered to manipulate $\mathrm{pH}$ (de Nooijer et al. 2009a; Bentov et al. 2009; Toyofuku et al. 2017), uptake Ca (Erez 2003; Toyofuku et al. 2008), and/ or control Mg (Bentov and Erez 2006) via cytological functions. The elemental and isotopic composition of foraminiferal calcareous tests has also constrained models for calcification (Elderfield et al. 1996; Bentov and Erez 2005). Recently, visualization methods using variable fluorescent indicators have become powerful tools for revealing the biomineralization process of foraminifera (Toyofuku et al. 2008; de Nooijer et al. 2008, 2009a, b; Bentov et al. 2009; Ohno et al. 2016; Toyofuku et al. 2017). The variety of results and partly contradicting hypotheses and models for foraminiferal calcification make it essentially impossible to predict their response to $\mathrm{OA}$ and enrichment of dissolved $\mathrm{CO}_{2}$ (de Nooijer et al. 2014). Indeed, the foraminiferal responses to $\mathrm{OA}$ are varied among species (Kuroyanagi et al. 2009; Fujita et al. 2011; Hikami et al. 2011; Keul et al. 2013).

Fluorescence observation has revealed that management of protons is important for foraminiferal calcification and for corals (e.g., Cai et al. 2016). The hyaline benthic species, Ammonia sp., show a large $\mathrm{pH}$ variation ( $\sim 2$ units) between the inside and outside of the site of 
calcification during the chamber formation process (de Nooijer et al. 2009a; Glas et al. 2012; Toyofuku et al. 2017). Visualization of the extracellular $\mathrm{pH}$ distribution around individuals shows that chamber formation is accompanied by a strong decrease in external $\mathrm{pH}$ from ambient to $\sim 7$ (Fig. 11). Meanwhile, the highest $\mathrm{pH}$ reaches more than 9 within the site of calcification. This decrease in external $\mathrm{pH}$ was observed over a wide range of $p \mathrm{CO}_{2}$ (from 460 up to $9010 \mu \mathrm{atm} /$ from pH 8.0 to 6.8) and the reduction in $\mathrm{pH}$ compared to that of the ambient seawater was relatively constant over the experimental conditions. The observed decrease in $\mathrm{pH}$ outside the site implies that these foraminifera actively pumped out protons via a physiological process, with the flux independent of initial external $p \mathrm{CO}_{2} / \mathrm{pH}$.

Under observation in the presence of a proton pump inhibitor (Bafilomycin $\mathrm{A}_{1}$ ), the external $\mathrm{pH}$ gradient disappeared (Toyofuku et al. 2017). Further, the specimens could no longer accomplish calcification. It is strongly suggested that proton transport is essential to the foraminiferal calcification process. Perhaps this is due to the conjugation of protons and $\mathrm{Ca}^{2+}$ exchange by an antiporter. These findings also suggest that the site of calcification of this species is well isolated from the ambient environment. Recently, these considerations have been supported by SEM observation on the site of calcification of Ammonia (Nagai et al. 2018; Fig. 12). The coverage of a thin layer $(\sim 1 \mu \mathrm{m})$ of a pseudopodial sheet extending over the entire specimen may be a strategy for maintaining oversaturation close to the chamber surfaces. As a consequence, the site of calcification may extend toward the pre-existing chambers and produce a thin layer of calcite over the pre-existing chambers to

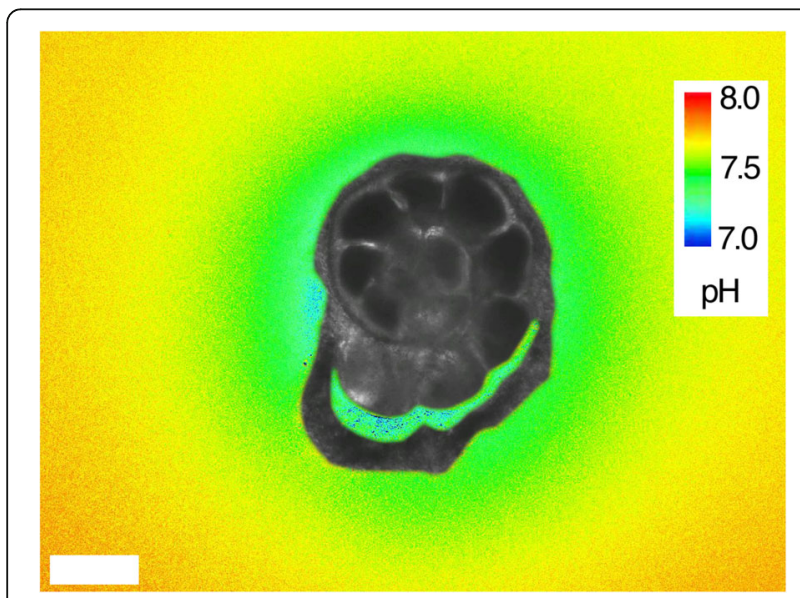

Fig. 11 Planar variability in $\mathrm{pH}$ around the calcifying specimen of Ammonia sp. in seawater with the $\mathrm{pH}$ indicator, pyranine. The gradient in $\mathrm{pH}$, which decreases toward the specimen, is mainly caused by proton diffusion away from the precipitation site. An image of foraminifera is superimposed on the pseudocolor pH image. Scale bars indicate $100 \mu \mathrm{m}$
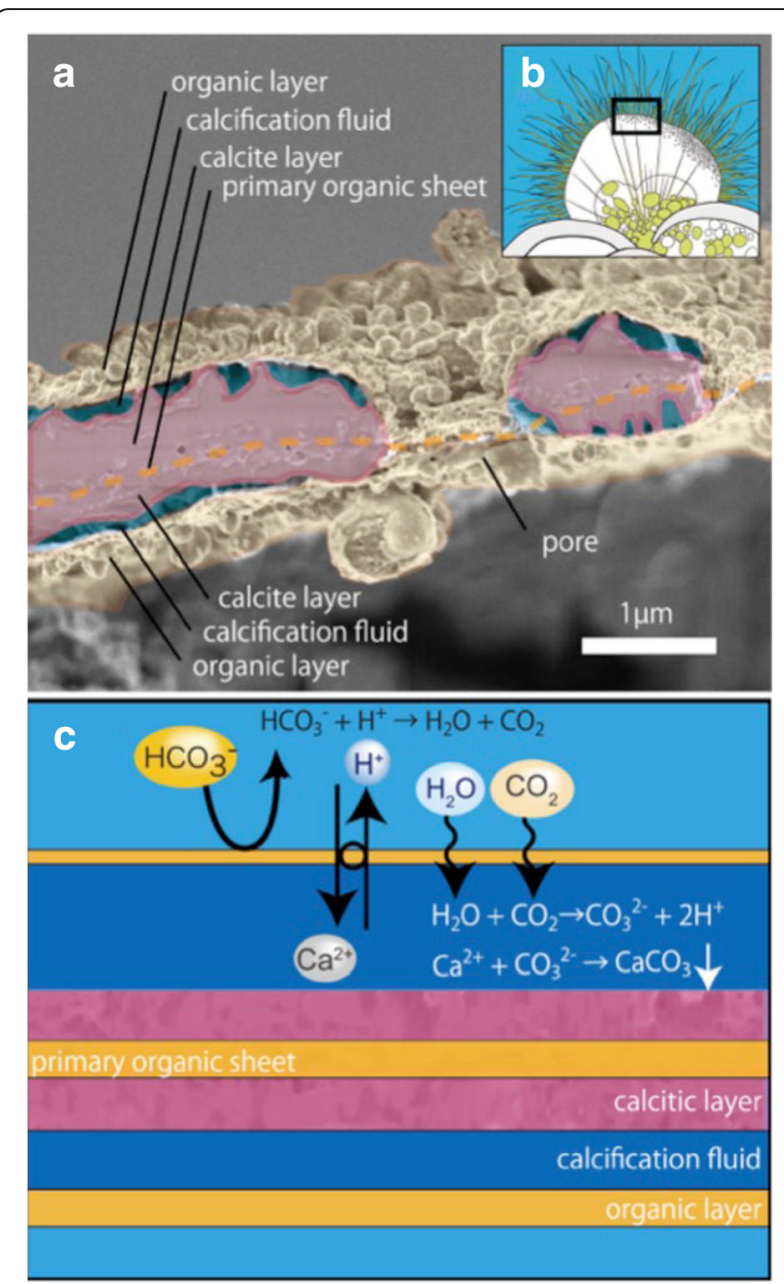

Fig. 12 Proton pumping-based model of rotaliid foraminiferal calcification at the enclosed site of calcification (SOC). a Magnified SEM image of the cross section of SOC. Upper side is the outer side, whereas the lower side is the cellular side. $\mathbf{b}$ Black rectangle indicates the observed newly calcifying chamber in (a). c Considerable calcification model based on Toyofuku et al. (2017) and Nagai et al. (2018). During chamber formation on an organic template (termed the primary organic sheet, POS), the organic layers isolate the growing calcite surface from the surrounding seawater. The chemical composition of the calcification fluid of the SOC is characterized by active, outward proton pumping coupled with an inward calcium ion-flux. The transported proton reduced $\mathrm{pH}$ around the foraminiferal microenvironment. Inorganic carbon speciation is shifted by this lower $\mathrm{pH}$, thereby increasing $\mathrm{pCO}_{2}$ of the surrounding seawater near the site of calcification. The large gradient in $\mathrm{pCO}_{2}$ around the individual results in the diffusion of $\mathrm{CO}_{2}$ into the site of calcification. This inbounded $\mathrm{CO}_{2}$ reacts to form carbonate ions due to the high $\mathrm{pH}$ at the site of calcification. This transported carbon source sustains $\mathrm{CaCO}_{3}$ precipitation by reacting with the inward- transported calcium ions

construct a unique multi-lamellar structure (Reiss 1958; Bé and Hemleben 1970; Grønlund and Hansen 1976).

Proton pumping in the calcification of Ammonia sp. Ammonia sp. are widely distributed in many coastal 
environments, including tidal flats, ports, and brackish lakes. Because of its resistance to a wide range of environmental variables, it is a genus popularly employed in laboratory cultures. It is also used to study geochemical signatures as a function of physical and chemical conditions. Further, Ammonia sp. serve as model species, whose chamber wall structure resembles that of many Rotalid species. The calcification of Ammonia sp. is characterized by strong gradients in $\mathrm{pH}$ and/or $p \mathrm{CO}_{2}$ between the site of calcification and the foraminiferal microenvironment. The results suggest that foraminiferal calcification would be regulated by DIC concentration rather than the calcite saturation state (Fig. 12). This uncoupling of saturation state and calcification explains the moderate response of many foraminifera to $\mathrm{OA}$ and the occurrence of calcareous foraminiferal communities at undersaturated conditions with respect to calcite but at high DIC concentrations (Keul et al. 2013; Flako-Zaritsky et al. 2011). The reduction in oceanic $\mathrm{pH}$ by increased oceanic $\mathrm{CO}_{2}$ uptake is relatively small compared with the $\mathrm{pH}$ decrease in the microenvironment during Ammonia's calcification. Hence, a relatively moderate decrease in $\mathrm{pH}$ may not impair foraminiferal calcification. Proton pumping is found to be the fundamental strategy for a variety of marine calcifiers (Ries 2011a). The high internal $\mathrm{pH}$ and large internal-external $\mathrm{pH}$ gap associated with foraminiferal calcification predicts that they may well produce more carbonate ions at the site of calcification even under elevated $p \mathrm{CO}_{2}$.

\section{Deep-sea carbonate dissolution and progressive foraminiferal shell dissolution}

A more severe influence of OA can be found in the deep sea, where carbonate tends to dissolve due to its higher solubility. This is controlled by the solubility product, which increases with depth (pressure), and by the increased acidity caused by the degradation of OM (Figs. 1 and 4, Table 1).

\section{Spatial and vertical heterogeneity in carbonaceous sediments in the deep sea}

The distribution of carbonate in marine sediment is inhomogeneous (e.g., Archer 1996). For example, regions with high carbonate content are mostly in the shallow oceanic ridges, whereas the deep ocean basins are almost completely devoid of carbonate due to its dissolution as a result of the high pressure, high $\left[\mathrm{CO}_{2}\right]$, low temperature, and hence, low saturation state (Eq. 4 in Fig. 1). These two realms are separated by a transition zone spanning several hundreds of meters in water depth, over which the carbonate content drops toward zero. The upper limit of the transition zone is termed the lysocline and lower limit of the transition zone is termed the carbonate compensation depth (CCD) (Fig. 4).
In the deep sea, the degree of seawater acidity also increases with the age of the water mass because of accumulating $\mathrm{CO}_{2}$, nitrate, and phosphoric acid derived from decomposed OM. Therefore, the depth of the transition zone is essentially influenced by deep water properties via thermohaline circulation and it becomes shallower as the age of the deep water increases (Broecker and Takahashi 1977). Actually, the sedimentary carbonate content in the Atlantic Ocean is generally higher than that of the Pacific Ocean. In particular, the carbonate content is almost zero in the North Pacific below $4000 \mathrm{~m}$. Most carbonate is dissolved in the deep sea in the North Pacific regardless of the high carbonate export flux (e.g., Kawahata 2002). The change in depth of the transition zone must be highly correlated with DIC and alkalinity contents in the global ocean (Figs. 2 and 4). Therefore, the dissolution and preservation of calcite play an important role in the global carbon cycle.

\section{Conventional proxies for carbonate dissolution}

Several proxies for carbonate dissolution have been proposed based on planktic foraminiferal shells. Berger (1968) proposed a dissolution index based on empirically ranked species of planktic foraminifera because they have a variety of morphologies and some of them are fragile and prone to dissolution. Similarly, benthic foraminifera normally have thick and smooth shells that are more resistant to dissolution than those of planktic foraminifera. Therefore, the planktic to benthic foraminiferal ratio in the sediment has been suggested as a dissolution proxy (Peterson and Prell 1985). However, the results depend on the initial makeup of the foraminiferal population in the sediment at the regional scale. The ratio of foraminiferal fragments to whole shells has been widely used as a calcite dissolution index (Peterson and Prell 1985). The advantage of the fragment ratio is its simplicity; however, its determination is often subjective. These methods are not calibrated against present-day pressure-normalized $\left[\mathrm{CO}_{3}{ }^{2-}\right]$.

The size-normalized shell weight of planktic foraminifera, which was first proposed by Lohmann (1995), is the most widely used method to reconstruct past $\left[\mathrm{CO}_{3}{ }^{2-}\right]$. Shell wall thickness and shell bulk density can be estimated using this method. A linear relationship between size-normalized shell weight and bottom-water calcite saturation state has been suggested (Broecker and Clark 2001, 2002). This method is based on an empirical calibration of bottom water $\left[\mathrm{CO}_{3}{ }^{2-}\right]$ or $\Omega_{\text {cal }}$, with the average weight of clean shells of selected species picked from narrow size ranges in core-top samples (e.g., de Villiers 2005). However, Barker and Elderfield (2002) showed that thickness of the foraminiferal shell walls varies with growth conditions. Spero et al. (1997) found strong correlations between shell weight and both water temperature and $\left[\mathrm{CO}_{3}{ }^{2-}\right]$; the warmer the water and the higher its $\left[\mathrm{CO}_{3}{ }^{2-}\right]$, 
the thicker the shells. Therefore, size-normalized shell weight techniques have uncertainties owing to the initial shell weight variation depending on $\Omega$ in the surface water.

\section{Developing proxies for carbonate dissolution using X-ray micro-computed tomography analysis}

Recent progress in X-ray micro-computed tomography (XMCT) has allowed researchers to observe the internal structures of foraminiferal shells and to evaluate shell dissolution intensity. Johnstone et al. (2010) used an XMCT scanner to observe the dissolution of foraminiferal shells from core top sediments and suggested that foraminiferal shells dissolve from the inner chamber walls and that the initial dissolution cannot be observed from outside of the shells. Furthermore, they divided the dissolution process of foraminiferal shells into five stages and proposed a new empirical dissolution index, XDX, based on the appearance of the CT images, and they provided a calibration to estimate $\Delta \mathrm{M}$ (the loss of test mass due to dissolution) from XDX.

In addition, XMCT makes it possible to quantitatively estimate shell density, and to observe a high-resolution density distribution in an individual shell. Iwasaki et al. (2015) used an XMCT scanner to estimate foraminiferal shell density and performed time series dissolution experiments with tests of planktic foraminifera, G. bulloides, in $\mathrm{pH}$-controlled undersaturated seawater in order to observe the initial stages of the dissolution process of G. bulloides tests (Fig. 13). They employed an XMCT system (ScanXmate-D160TSS105/11000, Comscantecno Co. Ltd., Kanagawa, Japan) to investigate the internal structure and density distribution of the shells. A high-resolution setting (X-ray focus spot diameter of $0.8 \mu \mathrm{m}, \mathrm{X}$-ray tube voltage of $80 \mathrm{kV}$, detector array size of $2000 \times 1336,1500$ projections $/ 360^{\circ}, 2.5 \mathrm{~s} /$ projection) was used for threedimensional (3-D) quantitative densitometry of small foraminiferal shells. The CT number, which is the normalized value of the calculated X-ray attenuation coefficient of a voxel in a computed tomogram, was used as an indicator of calcite density. In their study, comparison of CT and SEM images of the cross section of the outermost chamber of G. bulloides revealed that the inner calcite layer has a porous microgranular crystalline structure (low-density) and the outer calcite layer has a euhedral crystalline structure (high-density).

From their time series dissolution experiment, dissolution of the G. bulloides shell started from the central area of the shell and then spread to the porous inner calcite layer. In contrast, the outer calcite layer with a euhedral crystalline structure was resistant to dissolution and was well preserved (Fig. 13a, b). Such selective dissolution of the porous inner calcite layer was also evident as changes in the histogram of the CT numbers.
Using changes in the CT number histogram with the progression of shell dissolution, a quantitative proxy that allows quantitative measurements of carbonate loss from foraminiferal tests prior to carbonate dissolution was provided, which is not influenced by initial shell condition. Selective dissolution of the inner calcite layer and changes in the CT number histogram were also observed in G. bulloides shells from marine sediment samples (Fig. 13c, d), suggesting that the dissolution proxy based on XMCT scanning might be applicable to estimate the amount of carbonate dissolution at the deep-sea floor. Furthermore, characteristics of the shell dissolution process, accompanied by changes in the micro-scale crystalline structure, should be applicable to various species other than G. bullloides. Although several problems remain to be addressed (e.g., the time required for scanning and the imperfect understanding of the dissolution mechanism in the water column and in deep-sea sediments), a dissolution proxy utilizing the $\mathrm{CT}$ number histogram based on XMCT scanning has the potential to be the first viable method for accurately estimating the actual amount of calcite in seawater $\left[\mathrm{CO}_{3}{ }^{2-}\right]$.

\section{Response of marine calcifiers to different environments}

The Earth's surface has previously experienced a high $p \mathrm{CO}_{2}$ environment, which was generally associated with "hot house" conditions. Carbonate in the deep-sea was abruptly dissolved at the Paleocene/Eocene boundary due to severe OA. However, especially in the warm Cretaceous, abundant carbonate precipitated at the seafloor. These observations clearly demonstrate that high $p \mathrm{CO}_{2}$ alone did not always result in OA.

\section{Extreme warmth in the Cretaceous greenhouse system}

The mid-Cretaceous is widely accepted as the archetypal ice-free greenhouse interval in Earth's system history. To understand the greenhouse climate system, the Cretaceous paleoclimate has been widely discussed in relation to geological, geochemical, and paleontological records. Since early reports of mid-Cretaceous tropical and subtropical plants from the northern high latitude (e.g., Nathorst 1911), many paleontological studies have described a warm climate even at high latitudes (e.g., Tarduno et al. 1998). This warm climate is attributable to high $p \mathrm{CO}_{2}$ and possibly methane levels, in association with the high production rate of oceanic crusts, enhanced continental rifting, formation of large igneous provinces (LIPs), and metamorphic decarbonation (although volcanic activities releasing volcanic dust sometimes act as cooling events) (e.g., Larson 1991; Kuroda et al. 2007; Moriya 2011; Scudder et al. 2016; Brune et al. 2017).

The extensive warmth observed during the mid-Cretaceous is also supported by the oxygen isotopic paleothermometry of well-preserved planktic foraminifera 
a G. bulloides shell before dissolution (dissolution experiment)

CT image

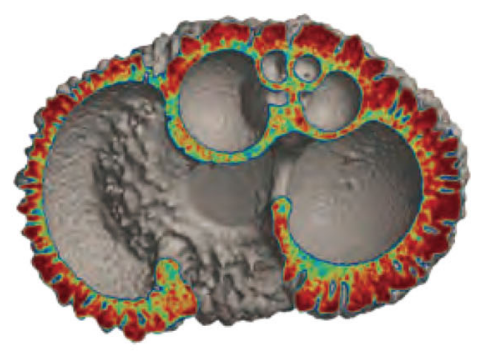

CT number histogram

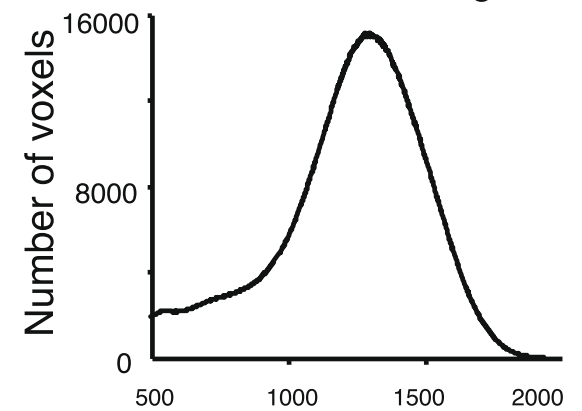

b G. bulloides shell on the sixth days dissolution (dissolution experiment)
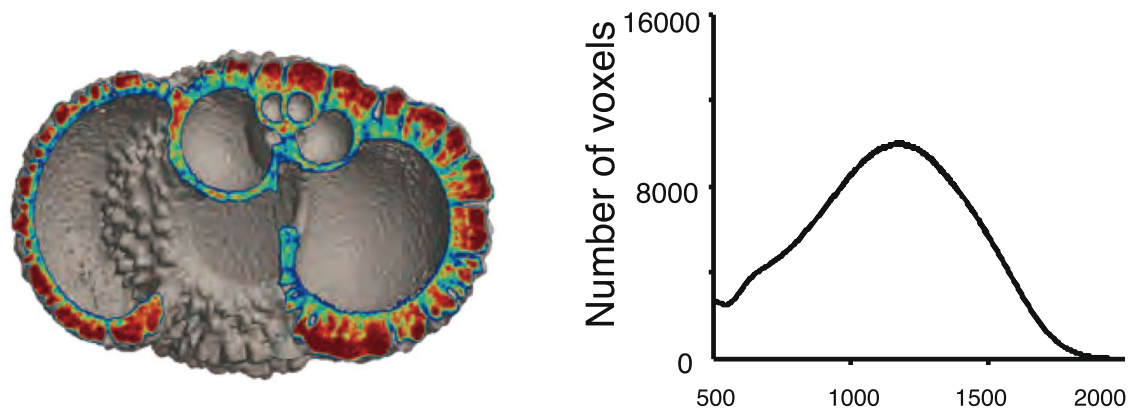

C G. bulloides shell from water depth of $1362 \mathrm{~m}$ (Sediment sample)
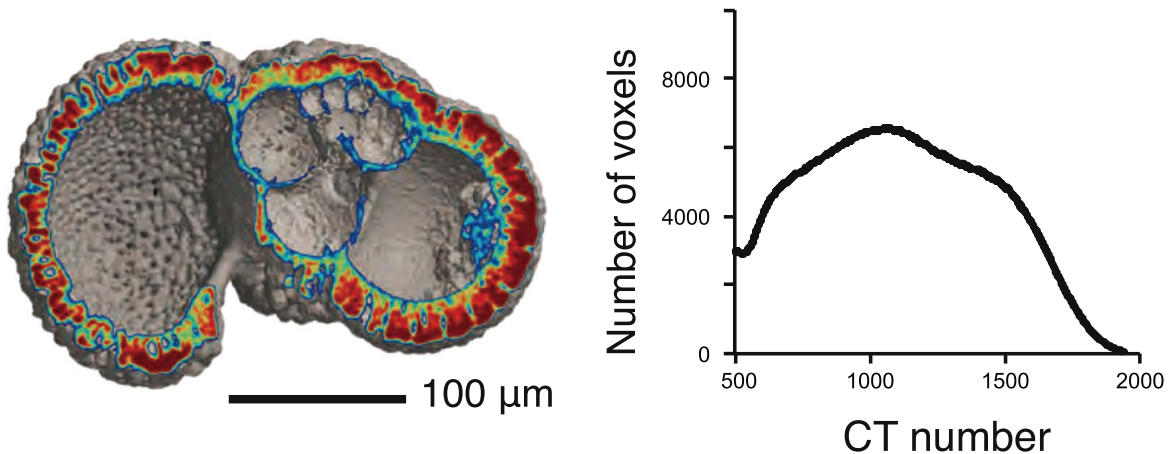

d G. bulloides shell from water depth of $3135 \mathrm{~m}$ (sediment sample)
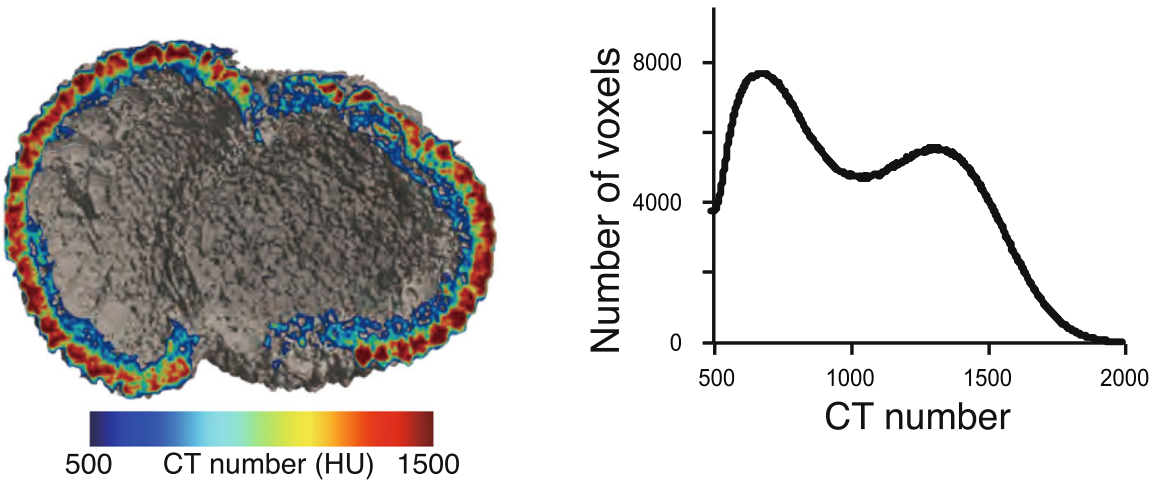
(See figure on previous page.)

Fig. 13 X-ray micro-CT cross-section images and histogram of CT number for G. bulloides shells: a original fresh shell before dissolution and $\mathbf{b}$ a partly dissolved shell after a low-pH condition in a 6-day dissolution experiment. c Relatively preserved shell and $\mathbf{d}$ relatively dissolved shell collected from the surface sediment at a water depth of $1362 \mathrm{~m}$ and $3135 \mathrm{~m}$ of the North western Pacific, respectively. As dissolution progressed, the inner side of the foraminiferal shell was selectively dissolved, and the mode of the CT number histogram gradually decreased. This $C T$ image was obtained by scanning using a X-ray micro-CT system (ScanXmate-D160TSS105/11000, Comscantecno Co. Ltd., Kanagawa, Japan) at the Tohoku University Museum. Data are cited from Iwasaki et al. (2015)

(so-called glassy foraminifera) (e.g., Wilson et al. 2002; Moriya et al. 2007; Bornemann et al. 2008; Friedrich et al. 2008). However, the Cretaceous equatorial sea surface temperature (SST) estimated in twentieth-century studies was less than $25^{\circ} \mathrm{C}$, which is much lower than it should be and even lower than the modern equatorial temperature. The highest SST of $29{ }^{\circ} \mathrm{C}$ in the modern ocean is observed in the Western Pacific Warm Pool (WPWP) (Fig. 14). From the surface, water temperature decreases vertically downward to $\sim 1{ }^{\circ} \mathrm{C}$ at the bottom of the modern equatorial Pacific, with a steep thermocline at $100-300 \mathrm{~m}$, indicating that the water column is well stratified in the modern equatorial ocean. Compared with the SST in the WPWP in the last glacial maximum, a value of $\sim 25{ }^{\circ} \mathrm{C}$ in the Cretaceous greenhouse world is surprisingly cool. This cool equatorial condition in the greenhouse world is termed the Cool Tropic Paradox (D'Hondt and Arthur 1996).

At the beginning of the twenty-first century, Pearson et al. (2001) found that early diagenesis on or just under the sea floor lowers the isotopic temperatures recorded in foraminiferal fossils. While many authors in the twentieth century utilized foraminiferal fossils with minor recrystallization for isotopic thermometry, new data generated from extremely well-preserved "glassy" foraminifera conclusively indicated that SSTs of the Cretaceous greenhouse were extremely high. Isotopic records show that mid-latitude SSTs of $\sim 25{ }^{\circ} \mathrm{C}$ were higher than the modern mid-latitude temperature (Fig. 14). The difference between the modern and Cretaceous SSTs becomes prominent in

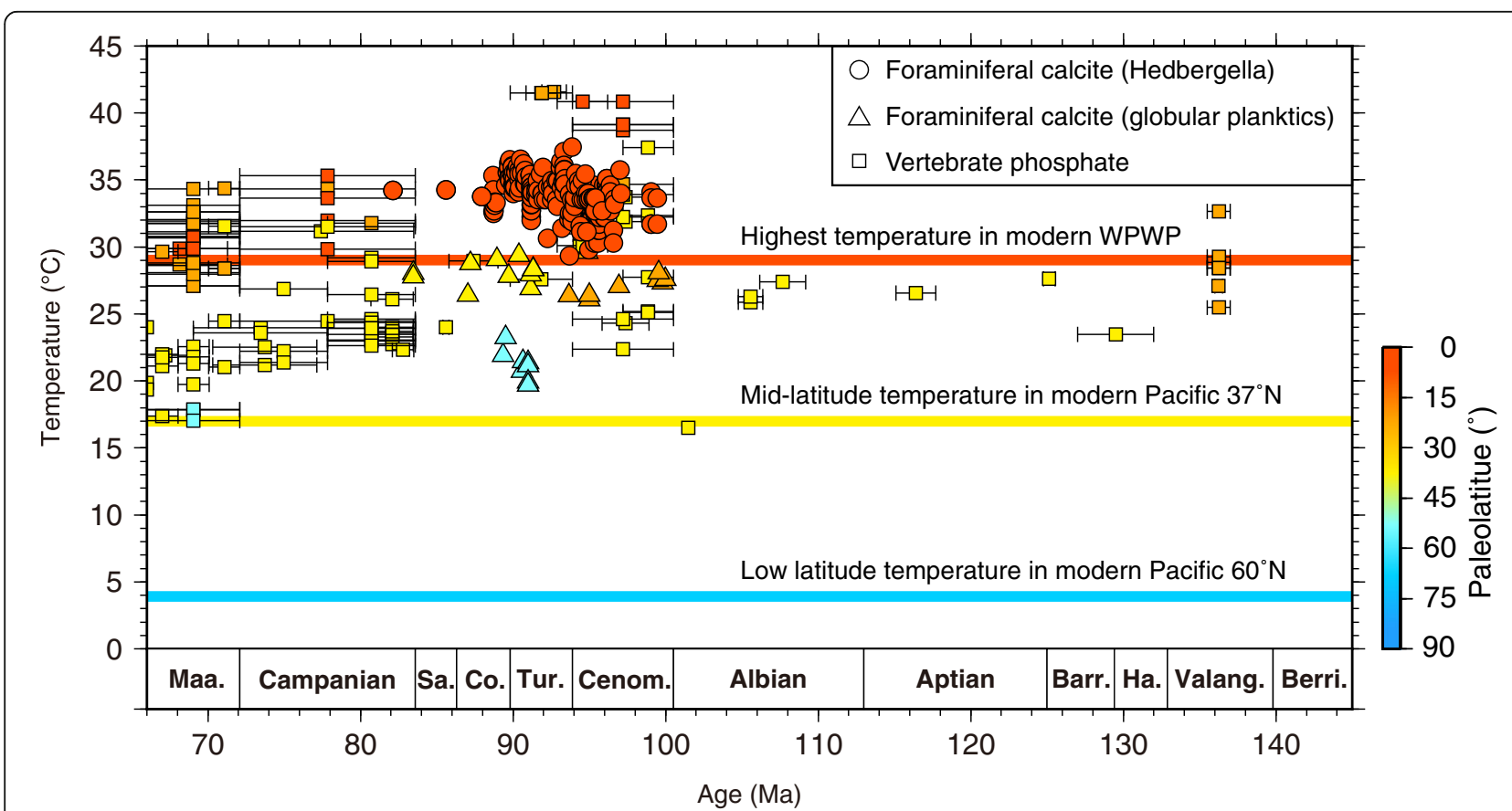

Fig. 14 Evolution of the Cretaceous ocean temperature estimated from oxygen isotopic records. Circles, triangles, and squares represent data from Hedbergella (planktic foraminifera), globular form planktic foraminifera, and surface dwelling vertebrate remains, respectively. Colors for each symbol indicate the paleolatitude where the data were obtained. While foraminifers were recovered from deep-sea cores, vertebrate remains occurred in outcrops, implying that vertebrate remains may not record open ocean temperatures. $\delta^{18} \mathrm{O}_{\mathrm{Sw}}$ is estimated as -1 (\%o, VSMOW) (Shackleton and Kennett 1975). $\delta^{18} \mathrm{O}_{\mathrm{sw}}$ is adjusted for latitudinal gradient in surface water $\delta^{18} \mathrm{O}_{\mathrm{sW}}$ (Zachos et al. 1994). Isotopic temperatures were calculated using the equations of Bemis et al. (1998) for foraminiferal calcites and Pucéat et al. (2010) for vertebrate remains. Paleolatitudes were computed by the Paleolatitude Calculator for Paleoclimate Studies (version 2.1) (van Hinsbergen et al. 2015) if they were not provided in the literature. Data are cited from Huber et al. (1999, 2002), Bice et al. (2003, 2006), Moriya et al. (2003; 2007; 201 1), Pucéat et al. (2003, 2007), Forster et al. (2007), and Bornemann et al. (2008). Maa. Maastrichtian, Sa. Santonian, Co. Coniacian, Tur. Turonian, Cenom. Cenomanian, Barr. Barremian, Ha. Hauterivian, Valang. Valanginian, Berri. Berriacian, WPWP Western Pacific Warm Pool 
the Cenomanian-Turonian ( $95 \mathrm{Ma})$, which appears to have been the warmest interval on Earth for at least the last 100 million years (e.g., Wilson et al. 2002). Background equatorial SSTs in this interval were $\sim 35^{\circ} \mathrm{C}$ and the highest SST exceeded $37{ }^{\circ} \mathrm{C}$, indicating the cirrus cloud negative-feedback hypothesis proposed for the modern ocean might not be valid, or that it had another steady state in the ice-free greenhouse system. Although SSTs became cooler in the late Cretaceous, equatorial and mid-latitude SSTs were still higher than those of the modern ocean.

The other notable disparity was a significantly weak meridional SST gradient in the Cretaceous. This was especially obvious in $\sim 90 \mathrm{Ma}$ (Fig. 14). While the Cretaceous SST gradient between the equator and $60^{\circ}$ in latitude is $\sim 14{ }^{\circ} \mathrm{C}$, the gradient in the modern ocean is $\sim 25^{\circ} \mathrm{C}$. This observation indicates enhanced heat transport from the equator to the poles in the Cretaceous greenhouse system. However, since numerical examinations (e.g., general circulation models) cannot simulate this weak SST gradient with reasonable $p \mathrm{CO}_{2}$, unknown heat transporting mechanisms in the greenhouse system or high concentrations of other greenhouse gases, such as methane, are expected (Bice et al. 2006). On the other hand, fully coupled models (e.g., CCMS [Community Climate System Model], MIROC [Model for Interdisciplinary Research on Climate], etc.) have been addressing this important problem. Upchurch et al. (2015) first succeeded in describing the weak meridional SST gradient without unreasonable artificial tuning. This significant advancement is opening the door to understanding the greenhouse climate system in collaboration with multi-site and -depth proxy archives.

\section{Stratified ocean in the Cretaceous greenhouse system}

It is well known that in the mid-Cretaceous, the greenhouse period, oceanic anoxic events (OAEs) occurred several times (e.g., Jenkyns 2010) due to the lower solubility of oxygen into the seawater at higher SST and lower ventilation of the water mass. One of the most interesting features of the anoxic sediments is that large quantities of organic carbon were often deposited in association with carbonates (e.g., nannoconid, foraminifera). In fact, well-preserved planktic foraminifera have been discovered from the black shale collected from ODP Site 1049 in Tethys (Norris and Wilson 1998), indicating that carbonate was not significantly dissolved even in suboxic or anoxic waters.

The oceanic redox state is a critical determinant in the evolutionary history of life on Earth (Raup and Sepkoski 1982). High turnover rates of fossil planktic species (planktic foraminifera and calcareous nanofossils) and radiolaria dwelling in the mid-water column have been observed at or near these OAEs (Leckie et al. 2002; Itaki 2016), although the critical boundary conditions for the survival of planktic foraminifera under low-oxygen concentrations remain obscure.

Culture experiments have examined the direct effects of dissolved oxygen concentration on planktic foraminifera. Kuroyanagi et al. (2013) cultured planktic foraminifera (both symbiont and non-symbiont species) under different oxygen levels. These foraminifera can survive, add chambers, feed, and undergo gametogenesis even under dysoxic conditions $\left(\sim 0.7 \mathrm{mg} \mathrm{O} \mathrm{L}^{-1}\right.$ or $\sim 22 \mathrm{mmol}$ $\mathrm{O}_{2} \mathrm{~m}^{-3}$ ). Furthermore, the gametogenesis rate and time to gametogenesis did not show any obvious trends across oxygen levels (Fig. 15). On the other hand, other results from the culture experiments showed that no planktic foraminifera could survive for more than $48 \mathrm{~h}$ in the presence of $\mathrm{H}_{2} \mathrm{~S}\left(\sim 2\right.$ and $\left.\sim 9 \mathrm{mg} \mathrm{H}_{2} \mathrm{~S} \mathrm{~L}^{-1}\right)$ (Kuroyanagi et al. 2019). Thus, critical boundary conditions for the survival of planktic foraminifera under low-oxygen concentrations are still unknown due to the difficulty of maintaining extremely low oxygen levels throughout a culture. Several studies have reported changes in oxygen-minimum zone conditions corresponding to planktic foraminiferal disappearance in Quaternary sediments (Fenton et al. 2000; Reichart et al. 2004). Under a "business-as-usual" scenario, modeling results have revealed a dramatic $50 \%$ increase in the suboxic water volume due to more stratified surface water with higher $\mathrm{CO}_{2}$ levels until $2100 \mathrm{AD}$ (Oschlies et al. 2008). Therefore, culturing planktic foraminifera under suboxic water conditions ( 0 to $\sim 20 \mathrm{mmol} \mathrm{O}_{2} \mathrm{~m}^{-3}$ ) might provide essential information and contribute to estimating changes in the future global carbon cycle.

\section{Warmth in the middle Eocene climatic optimum event and foraminiferal photosymbiosis}

The Eocene epoch is characterized by overall warmth, with a gradual cooling trend and short-term hyperthermal events. The SST at low latitudes was estimated to be as high as $30-35^{\circ} \mathrm{C}$ (Pearson et al. 2007). Especially during the extreme warmth of the middle Eocene climatic optimum (MECO) event, $p \mathrm{CO}_{2}$ increased by a factor of 2 to 3 , and SST rose by $3-6{ }^{\circ} \mathrm{C}$ to exceed $28{ }^{\circ} \mathrm{C}$ even in southern high latitudes (Bijl et al. 2010). Such conditions might be disastrous to photosymbiotic organisms based on our current knowledge on modern coral "bleaching," i.e., a collapse of photosymbiosis, via heat stress. It is pointed out that symbiont "bleaching" might have also occurred in planktic foraminifera.

The photosymbiotic ecology of planktic foraminifera can be detected even from fossils with stable isotopic signatures of symbiont photosynthesis recorded in foraminiferal tests (Oppo and Fairbanks 1989; Norris 1996). A characteristic carbon isotopic signature has been used as an indicator; the $\delta^{13} \mathrm{C}$ value of symbiont-bearing species is more ${ }^{13} \mathrm{C}$-enriched than the non-symbiotic 


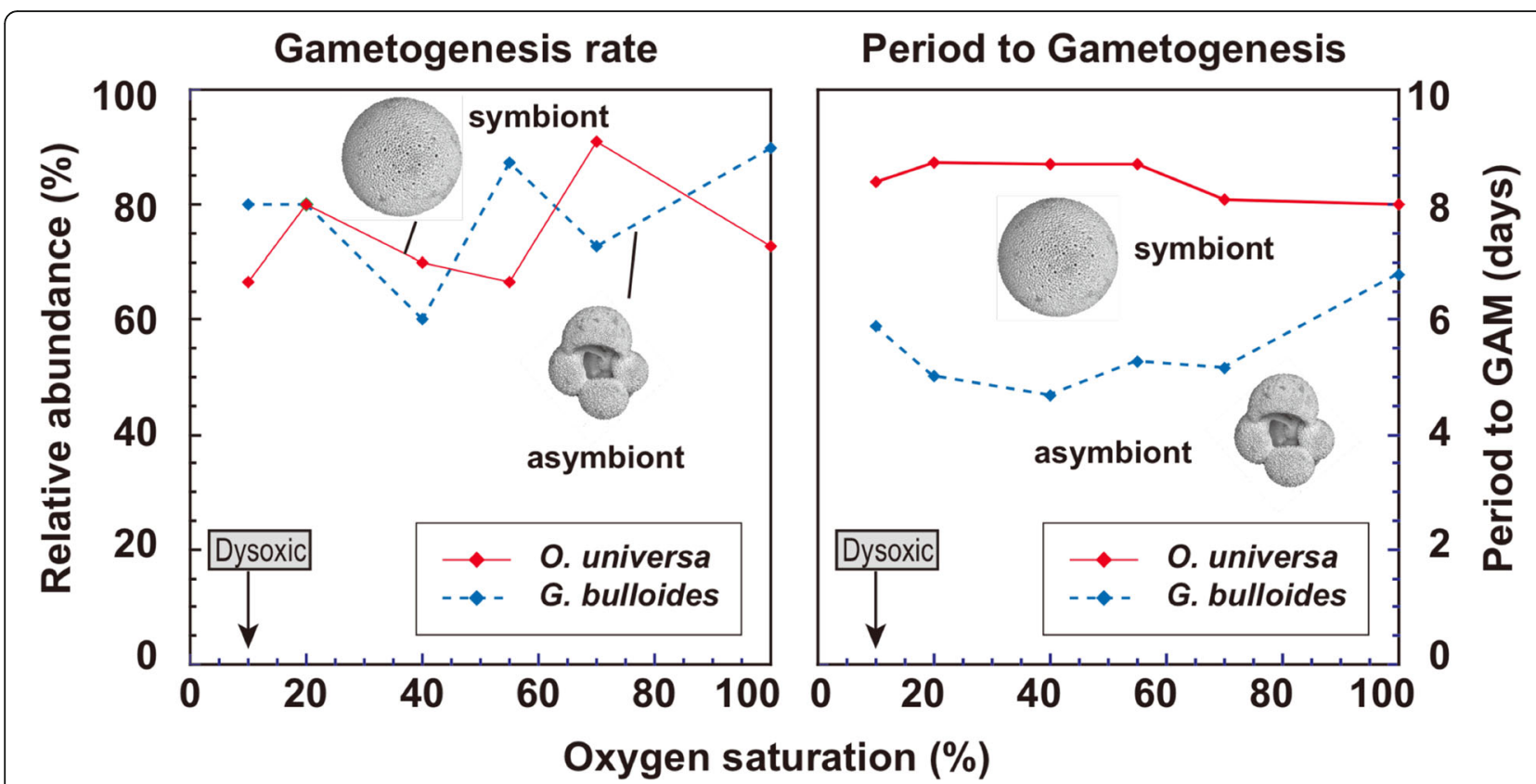

Fig. 15 Gametogenesis rates (left) and days to gametogenesis (right) in Orbulina universa (solid red line) and Globigerina bulloides (broken blue line) at different dissolved oxygen (DO) saturation levels (figure modified from Kuroyanagi et al. 2013). Although DO environments are classified differently in different studies (e.g., Jorissen et al. 2007), a DO of $10 \%\left(\sim 0.7 \mathrm{mg} \mathrm{O}_{2} \mathrm{~L}^{-1}\right.$ or $\left.\sim 22 \mathrm{mmol} \mathrm{O}_{2} \mathrm{~m}^{-3}\right)$ was generally classified as "dysoxic"

species, reflecting a selective incorporation of ${ }^{12} \mathrm{C}$ during symbiont photosynthesis ("photosymbiotic effect"); the greater the symbiont photosynthesis, the larger the effect. Therefore, the effect is enhanced as the host grows its body size and progressively increases the number of the symbionts. This results in a positive relationship between test size and $\delta^{13} \mathrm{C}$. Based on this concept, many authors have studied the size-related $\delta^{13} \mathrm{C}$ profiles of fossil foraminiferal tests of extinct species to identify their photosymbiotic ecology (e.g., Norris 1996; Bornemann and Norris 2007; Birch et al. 2012). Moreover, the $\delta^{13} \mathrm{C} /$ size positive gradient has been used as an indicator of the intensity of the photosynthetic activity of symbionts (Kelly et al. 1996; Wade et al. 2008; Edgar et al. 2013).

The $\delta^{13} \mathrm{C} /$ size positive gradient of some photosymbiotic species deteriorated during the peak MECO conditions, as compared with pre-event and post-event levels (Edgar et al. 2013). This deterioration could be attributed to symbiont "bleaching" during the higher SSTs in the peak MECO period. Despite these possible crises of photosymbiosis, many Eocene planktic foraminifera are thought to have been photosymbiotic (Pearson et al. 2006). The chamber-by-chamber isotopic profiles of three representative Eocene genera, Morozovella, Acarinina (both known as symbiotic), and Subbotina (known as non-symbiotic), recovered from IODP Site U1407 exemplify these ecologies. As expected, the results revealed a clear contrast in $\delta^{13} \mathrm{C}$ profile between the symbiotic and non-symbiotic species (Fig. 16a, b).
A notable finding here is that the last chamber of the two symbiotic species showed remarkably low $\delta^{13} \mathrm{C}$ values, comparable with that of the non-symbiotic Subbotina. This may indicate that at the time of calcification of the last chamber, these two symbiotic species became virtually "non-symbiotic" with the loss of their symbionts. This may have been caused by the digestion or dissolution of the symbionts, as seen in cultured modern photosymbiotic species (Bé et al. 1983; Takagi et al. 2016a). The modern and fossil examples of symbiont loss mentioned above should be part of the natural life processes of foraminifera. Such lack of a "photosymbiotic effect" in only the last chamber cannot be identified using conventional $\delta^{13} \mathrm{C} /$ size methods. However, it can be distinguished in chamber-by-chamber $\delta^{13} \mathrm{C}$ profiles (Fig. 16a). Therefore, a change in photosymbiotic activity, or even a "bleaching" phenomenon, can theoretically be identified by precise $\delta^{13} \mathrm{C}$ analyses of individual chambers.

Although the possibility of "bleaching" in the Eocene warm period cannot be denied, caution should be used when interpreting the $\delta^{13} \mathrm{C}$ profiles. Following the rule of metabolic rates, an elevation of SST enhances both photosynthetic rates and respiration rates with different temperature sensitivities. Temperature sensitivity is higher for respiration than for photosynthesis (e.g., Lombard et al. 2009). This means that deterioration of the $\delta^{13} \mathrm{C}$ gradient can also be caused by elevation of the respiration rate under high SST conditions because the effect of respiration on test $\delta^{13} \mathrm{C}$ shows the opposite trend. When 


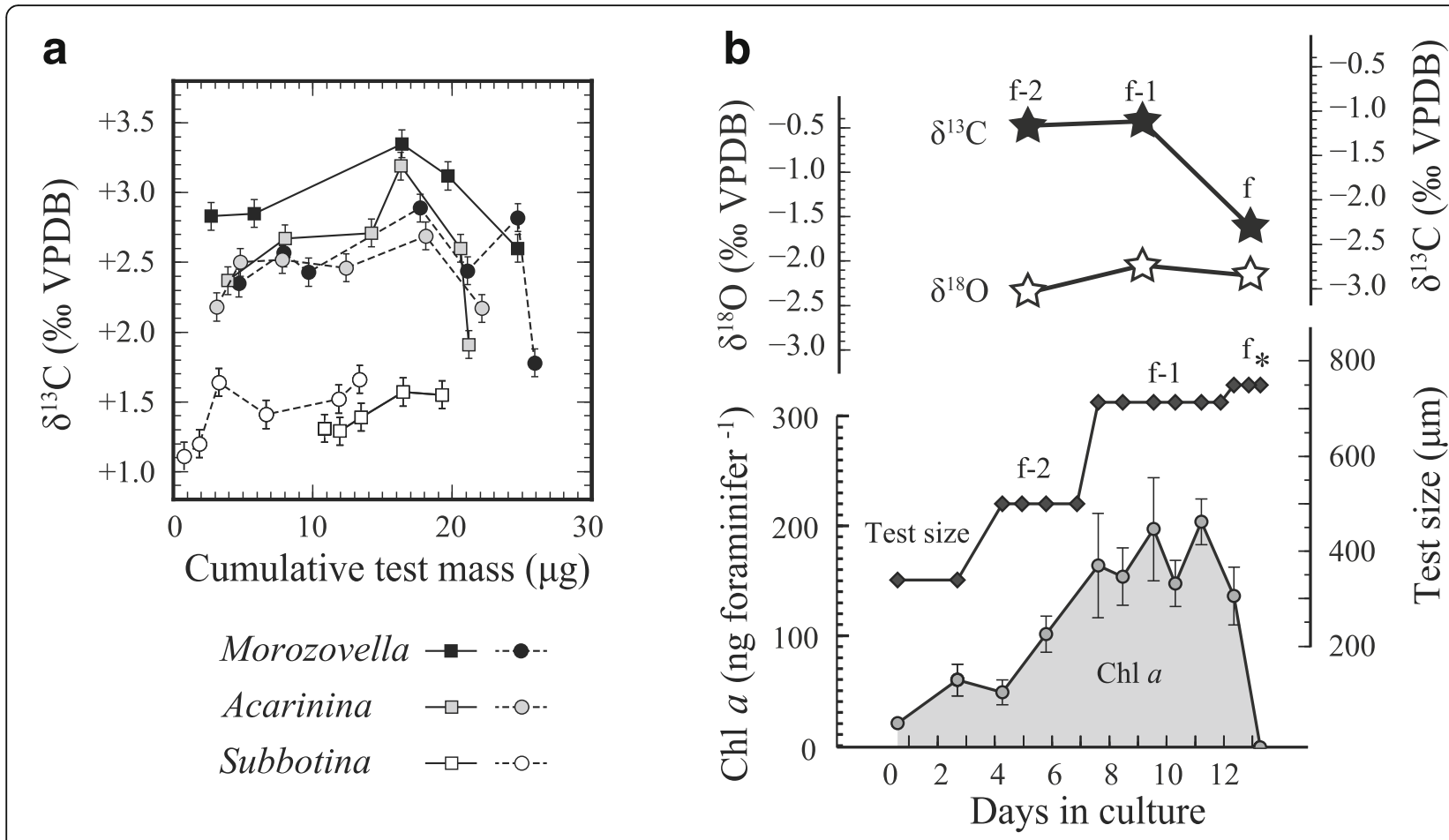

Fig. 16 Comparison of isotopic results for Eocene species and modern cultured photosymbiotic species. a Chamber-by-chamber $\delta^{13} \mathrm{C}$ versus cumulative test mass of Eocene species. The same shade is used for symbols of the same species (black: Morozovella crater; gray: Acarinina cuneicamerata; white: Subbotina eocaena). Data for the same individual are connected in ontogenetic order. Error bars represent analytical errors $( \pm 0.1 \%$ ). Each individual test was dissected into chambers using a micro-blade (e.g., Takagi et al. 2015; 2016b), then analyzed by a customized continuous-flow mass spectrometry system that can measure micro-volume carbonate as small as a single chamber (Ishimura et al. 2004, 2008). Symbiotic species Morozovella and Acarinina tended to show slight positive shifts until the penultimate chamber and then the final chamber showed drastically more ${ }^{13} \mathrm{C}$-depleted $\delta^{13} \mathrm{C}$ (values $0.5-1.0 \%$ ). In contrast to these species, Subbotina showed comparatively ${ }^{13} \mathrm{C}$-depleted $\delta^{13} \mathrm{C}$ values through its ontogeny, which is in good agreement with the known non-symbiotic nature of this species. $\mathbf{b}$ Growth and test isotopic results for the modern symbiotic species Globigerinoides sacculifer cultured in a laboratory (Takagi et al., 2018). Chlorophyll-a content of the individual was estimated using an active chlorophyll fluorometry in a non-destructive manner. After the gametes release, chambers precipitated during culture were dissected and $\delta^{13} \mathrm{C}$ and $\delta^{18} \mathrm{O}$ were analyzed. Data are partly from Takagi et al. (2016a). The decrease of $\delta^{13} \mathrm{C}$ was accompanied by a decrease in (or almost zero) photosynthesis at the final stage, indicating that the lack of photosynthesis could be clearly depicted from the chamber-by-chamber isotopic profiles

comparing the $\delta^{13} \mathrm{C} /$ size gradient at different time slices with different climates, attention must be paid to the balance of photosynthesis and respiration under each SST. In any case, to our best knowledge, no "bleaching" phenomenon due to high temperature has been reported for modern planktic foraminifera under laboratory culture.

Interestingly, through the macroevolutionary history of Cenozoic planktic foraminifera, the proportion of photosymbiotic species to the total number of species corresponds well to the pattern of Earth's climate change (Fig. 17). This proportion became larger during hyperthermal events like the Paleocene/Eocene thermal maximum, Early Eocene climatic optimum, and MECO. This suggests that the photosymbiotic association with algae would make foraminifera more adaptive to such hot climates and accelerated their speciation. In addition to such adaptivity in the evolutionary scale, it is important to understand the individual-scale mechanism of photosymbiosis. Since an individual holobiont is involved with photosynthesis, respiration, and calcification, the net fitness of the photosymbiotic system is difficult to evaluate.

\section{Perturbation in global carbon cycle at the Paleocene/Eocene boundary}

The P/E transition event at $55.5 \mathrm{Ma}$ is often referred to as the Paleocene/Eocene thermal maximum, characterized by a huge concomitant perturbation in the global carbon cycle (Zachos et al. 2001). Large $\delta^{13} \mathrm{C}$ anomalies observed in deep-sea sediments, terrestrial soil carbonates, and mammal teeth (associated with a major turnover in land mammal assemblages), was $-3 \%$ (up to $-6 \%$ ) over an interval of 100-200 kyr near the end of the Paleocene (Kennett and Stott 1991; Norris and Röhl 1999; Pagani et al. 2006). The duration of these events was estimated to be no more than $10 \mathrm{kyr}$, with $\mathrm{P} / \mathrm{E}$ transition conditions with a total duration of about $215 \pm 5 \mathrm{kyr}$ for $\delta^{13} \mathrm{C}$ excursion (Röhl et al. 2000) (Fig. 18). Benthic foraminiferal $\delta^{18} \mathrm{O}$ values indicate that oceanic deep waters warmed 


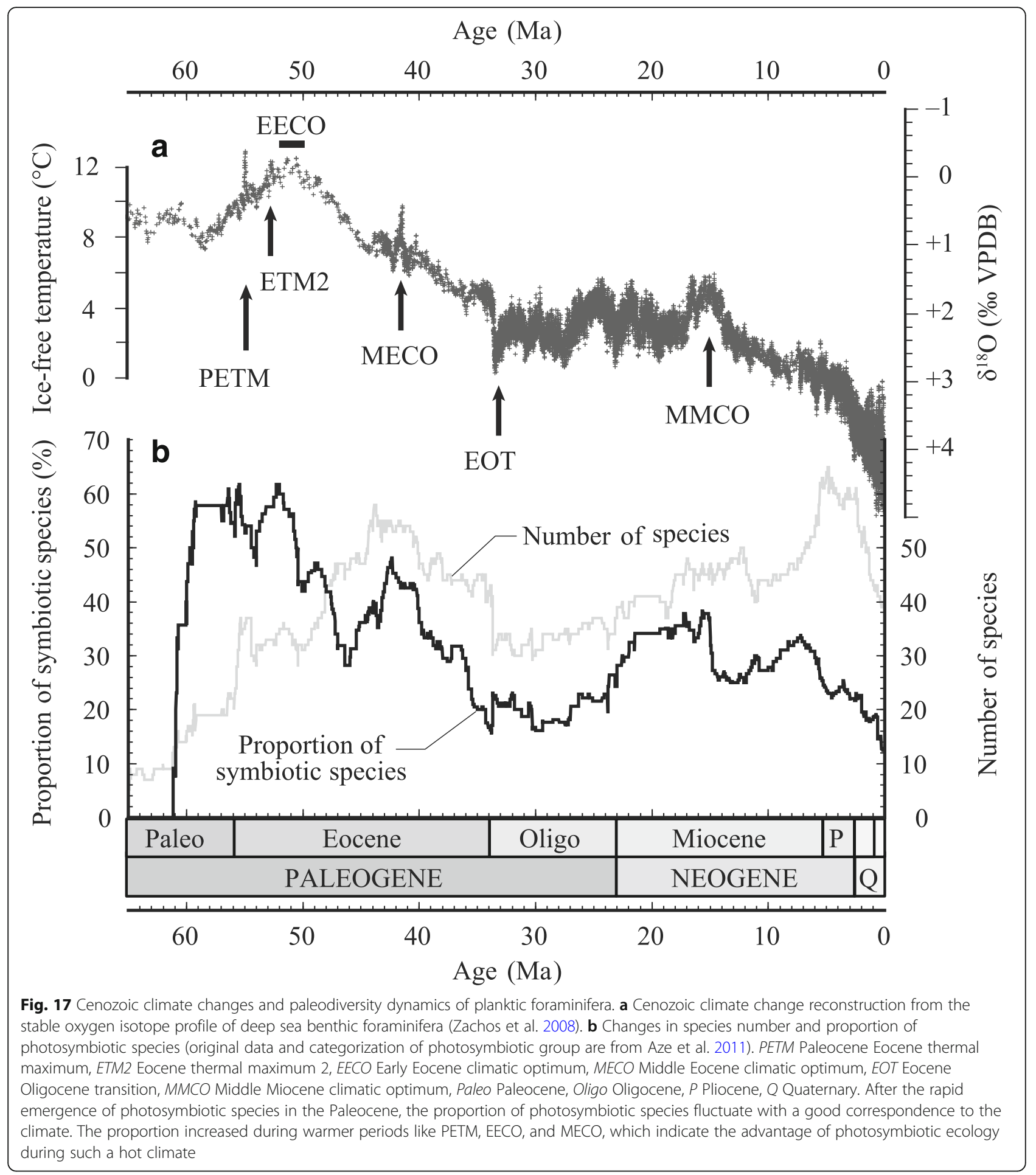

substantially worldwide, from $\sim 10$ to $\sim 18{ }^{\circ} \mathrm{C}$ in high latitudes (Kennett and Stott 1991) and from $\sim 10$ to $\sim 16{ }^{\circ} \mathrm{C}$ in the tropics (Bralower et al. 1997). SSTs, as recorded by planktic foraminiferal $\delta^{18} \mathrm{O}$ and/or $\mathrm{Mg} / \mathrm{Ca}$ values, showed little change (from $\sim 26$ to $\sim 28{ }^{\circ} \mathrm{C}$ ) at low latitudes but larger increases at high latitudes, leading to diminished vertical and latitudinal thermal gradients (e.g., Kennett and Stott 1991; Kelly et al. 1996).

Actually, the declines in coral reefs could be attributed to an SST in the tropics that was beyond the maximum temperature range of corals (Scheibner and Speijer 2008). In terrestrial environments, a widespread increase in 


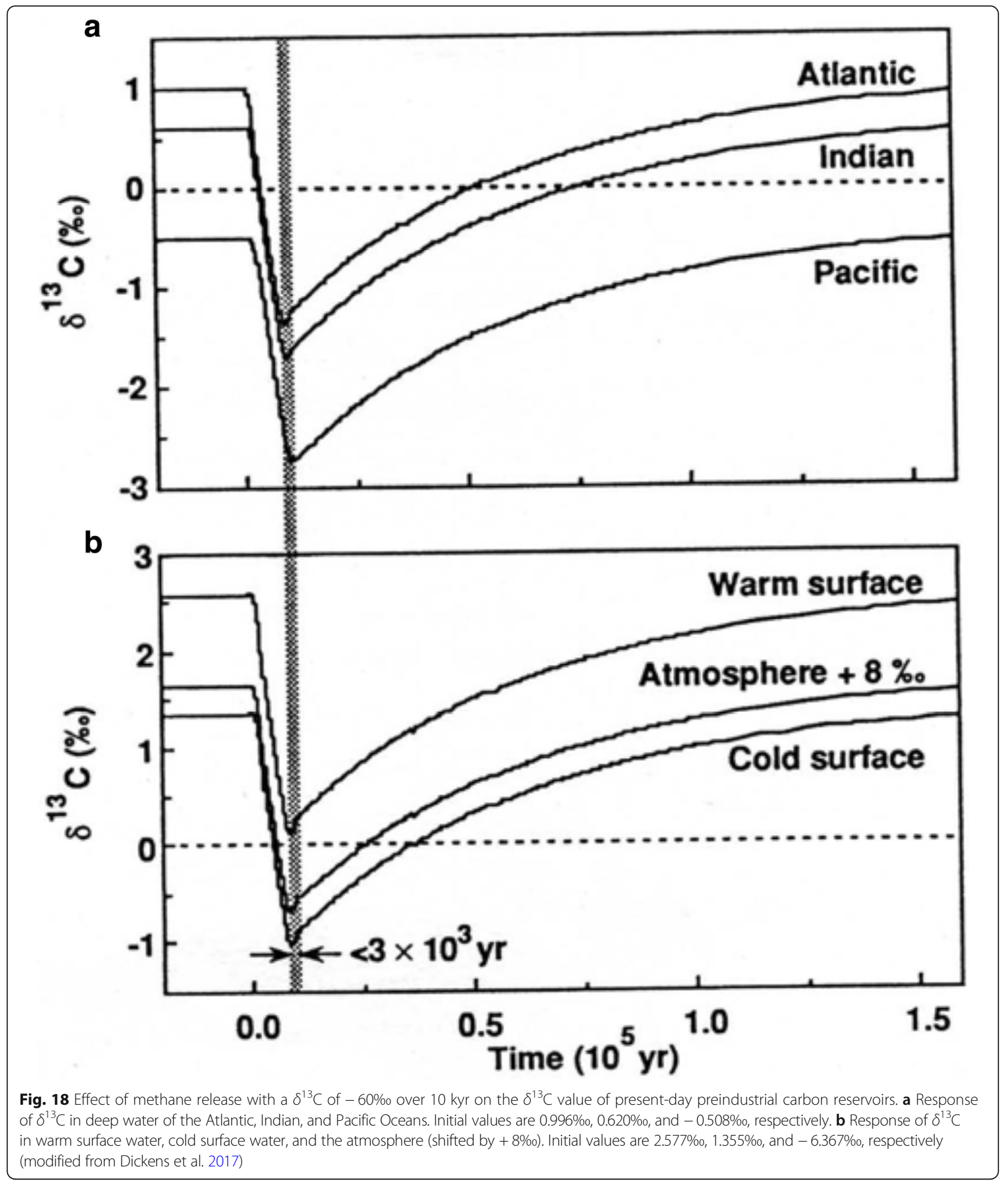

kaolinite was interpreted to herald a warm and wet climate. In association with these environmental changes, ocean circulation, primary productivity, carbonate dissolution, and the hydrologic cycle showed severely disturbed wide-ranging environments (Ernst et al. 2006; Stassen et al. 2012). In order to explain the large negative shift in $\delta^{13} \mathrm{C}$ value, the dissociation of a large amount of methane hydrate (with a $\delta^{13} \mathrm{C}$ of $-60 \%$ ) is considered to be the most plausible mechanism (e.g., Dickens et al. 1997). The amount of carbon required to explain the 
negative $\delta{ }^{13} \mathrm{C}$ shift is estimated to be as large as $2000 \mathrm{PgC}\left(1 \mathrm{PgC}=10^{15} \mathrm{~g}\right.$ of carbon) (Dickens et al. 1997; Zachos et al. 2005).

In oxygenated condition, the injected methane is easily converted to $\mathrm{CO}_{2}$ within a few years. Carbon dioxide is weakly acidic; therefore, it would lead to a reduction in deep-sea $\mathrm{pH}$, possibly triggering a rapid (<10 kyr) shoaling of the global CCD by $>2 \mathrm{~km}$, followed by gradual recovery (> 100 kyr) (Zachos et al. 2005). The $\delta{ }^{13} \mathrm{C}$ anomaly also coincides with the most dramatic extinction of $35-50 \%$ of cosmopolitan benthic foraminifera in the past 100 million years and an apparent change in the dominance of calcareous to agglutinated benthic fauna at some deep seafloor sites (Kawahata et al. 2015). Carbonate saturation level was more reduced by the higher pressure in the deep-sea.

Such characteristics make the $\mathrm{P} / \mathrm{E}$ transition event a possible analog of the modern human perturbation to the ocean-atmosphere carbon system. At the P/E transition, methane was rapidly released to the ocean and atmosphere at an average rate of $\sim 0.2 \mathrm{PgC}_{\text {year }}{ }^{-1}$ of $\mathrm{CO}_{2}$ over 10 kyr (Dickens et al. 1997; Zachos et al. 2005). This rate is approximately $1 / 30$ of the current global emission rate $\left(\sim 7.8 \mathrm{PgC}_{\text {ear }}^{-1}\right)$ of anthropogenic carbon input.

\section{Long-term neutralizing process against enhanced $\mathrm{pCO}_{2}$}

Terrestrial waters stimulate physical and chemical weathering of both silicate and carbonate rocks and transport $\mathrm{HCO}_{3}{ }^{-}$as well as other forms of dissolved and particulate carbon from land to the ocean (Eqs. 2 and 3) (e.g., Hecht and Oguchi 2017). In particular, silicate chemical weathering is one of the most important processes working as a net sink of $\mathrm{CO}_{2}$. Therefore, it also functions as neutralizing process against $\mathrm{OA}$.

It is generally assumed that one of the most active chemical weathering scenarios globally occurs in the high Himalaya, as a result of the ongoing uplift of the Himalayan-Tibetan Plateau and the heavy rains associated with the Indian-Asian monsoon, which is also linked with the North Pacific monsoon (e.g., Tada and Murray 2016; Tada et al. 2016; Clift 2017; Dado and Takahashi 2017). Gaillardet et al. (1999) compiled dissolved major ion data in Himalayan Rivers and reported high chemical weathering rates for silicate in the Ganges-Brahmaputra and Ayeyarwady Rivers, and for carbonate in the Yangtze River. Raymo et al. (1988) and Raymo (1991) focused on the $\mathrm{Sr}$ isotope record in marine sedimentary cores and found that active silicate weathering in this area may have triggered global cooling during the Eocene. However, the importance of a long-term $\mathrm{CO}_{2}$ sink by silicate weathering in this area has been questioned in recent studies. Bickle et al. $(2001,2003)$ reported that $\mathrm{Sr}$ isotopes cannot be used as a proxy for silicate weathering owing to regional metamorphism in this area. Manaka et al. (2015a) noted that the silicate weathering rate reported in previous studies for the Ayeyarwady River were largely overestimated, and they recalculated the $\mathrm{CO}_{2}$ consumption rates by silicate and carbonate weathering in the entire Himalayan river basin, reporting values of $0.012 \mathrm{PgC}_{\text {year }}{ }^{-1}$ and $0.024 \mathrm{PgC}$ year $^{-1}$, respectively. In contrast, FranceLanord and Derry (1997) proposed that erosion of organic carbon and its burial in the Bengal Fan may have controlled the global carbon cycle and climate change in this era.

The estimated global $\mathrm{CO}_{2}$ consumption rates by silicate and carbonate weathering are $0.13 \mathrm{PgC}_{\text {year }}{ }^{-1}$ and 0.15 PgC year $^{-1}$, respectively, based on the chemical compositions of major world rivers given by Gaillardet et al. (1999) and modified data for the Ayeyarwady Rivers by Manaka et al. (2015a, b). Hartmann et al. (2009) highlighted extremely high silicate weathering rates in small areas such as the Pacific islands (so-called hyperactive areas and hot spots), based on a high-resolution global lithological map and the calculated weathering rate of each rock types.

Current global warming will continue to be a pressing problem over timescales of decades to centuries because the anthropogenic $\mathrm{CO}_{2}$ release rate from fossil fuel use and cement production is 7.8 $\mathrm{PgC} \mathrm{year}^{-1}$ (IPCC 2013a), much larger than the $\mathrm{CO}_{2}$ consumption rate of chemical weathering (Table 2). Anthropogenic land use changes such as deforestation also lead to a carbon release of 1.1 PgC year $^{-1}$ to the atmosphere. Currently, a half of anthropogenic $\mathrm{CO}_{2}$ release remains in the atmosphere (average atmospheric increase: $4 \mathrm{PgC}$ year $^{-1}$ ), while approximately a quarter is absorbed into the terrestrial biosphere and the ocean. Terrestrial photosynthesis absorbs 123.0 PgC year ${ }^{-1} \mathrm{CO}_{2}$, most of which (118.7 $\mathrm{PgC} \mathrm{year}^{-1}$ ) is returned to the atmosphere via the respiration process. Net $\mathrm{CO}_{2}$ uptake by the terrestrial biosphere is only 4.3 PgC year ${ }^{-1}$.

The $p \mathrm{CO}_{2}$ in the global terrestrial waters of lower alluvial basins with well-developed soils and active agriculture is often over several thousand $\mu$ atm, much higher than the atmospheric level (400 $\mu \mathrm{atm})$ (Cole et al. 2007; Raymond et al. 2013; Manaka et al. 2015b). Terrestrial waters can receive $1.9 \mathrm{PgC} \mathrm{year}^{-1}$ of soil carbon, which was originally fixed by the photosynthesis process (Regnier et al. 2013). The global riverine flux of carbon to the ocean is $1.06 \mathrm{PgC}_{\text {year }}{ }^{-1}$ (Li et al. 2017), which could enhance $p \mathrm{CO}_{2}$ in coastal regions. Soil-derived carbon, mainly dissolved organic carbon, is decomposed in the water and released directly to the atmosphere in the form of $\mathrm{CO}_{2}$ (Rasilo et al. 2017). The global $\mathrm{CO}_{2}$ degassing rate from water is $1.1 \mathrm{PgC}_{\text {year }}{ }^{-1}$, which is comparable in magnitude to that from fossil fuel and cement. One of the largest $\mathrm{CO}_{2}$ evasions is reported for the Amazon River; the estimated flux is as high as $0.47 \mathrm{PgC}_{\text {year }}{ }^{-1}$ from the entire basin (Richey et al. 2002). 
Table 2 Global carbon exchange between land, inland waters, ocean, and atmosphere since the industrial era

\begin{tabular}{lll}
\hline & Pg C year ${ }^{-1}$ & References \\
$\mathrm{CO}_{2}$ Consumption by chemical weathering of silicates in Himalayan River Basins & 0.012 & Manaka et al. (2015a, b) \\
$\mathrm{CO}_{2}$ Consumption by chemical weathering of carbonates in Himalayan River Basins & 0.024 & \\
Global $\mathrm{CO}_{2}$ consumption by chemical weathering of silicates & 0.132 & Gaillardet et al. (1999); Manaka et al. (2015a, b) \\
Global $\mathrm{CO}_{2}$ consumption by chemical weathering of carbonates & 0.149 & \\
$\mathrm{CO}_{2}$ release to the atmosphere by fossil fuel use and cement production & 7.8 & IPCC (2013) \\
$\mathrm{CO}_{2}$ release to the atmosphere by anthropogenic land Use change & 1.1 & 123.0 \\
Total terrestrial photosynthesis & 118.7 & \\
Total terrestrial respiration & 4.3 & Regnier et al. (2013) \\
Net atmospheric CO & & \\
Total soil carbon input from land to inland waters & 1.9 & Li et al. (2017) \\
Global riverine flux of carbon to the ocean & 1.06 & Regnier et al. (2013) \\
$\mathrm{CO}_{2}$ release from inland waters to the atmosphere & 1.1 & \\
\hline
\end{tabular}

For future environments, global warming is expected to enhance both chemical weathering (IPCC 2013a) and soil respiration (Hashimoto et al. 2015). This warming is predicted to cause extreme rainfall events, particularly in the Himalayan lowland alluvium, which may further increase $p \mathrm{CO}_{2}$ of river water (Goswami et al. 2006). Anthropogenic eutrophication in aquatic ecosystems is another widespread problem globally (Mackenzie et al. 2002). Cai et al. (2011) reported that large riverine inputs of nutrients, as well as $\mathrm{OM}$ and dissolved $\mathrm{CO}_{2}$, can enhance the acidification of subsurface coastal waters. In contrast, this eutrophication can enhance photosynthesis, and thus $\mathrm{CO}_{2}$ uptake, in enclosed conditions such as lakes, which may be important to the carbon cycle, particularly in developing countries (Manaka et al. 2013). Therefore, changes in water composition in response to environmental change should be borne in mind in the future.

\section{Inventory of alkalinity required for the preservation of deep-sea carbonate}

In order to understand the relationship between carbonate dissolution and $p \mathrm{CO}_{2}$ in deep sea, a simple ocean carbon cycle model was used based on the three-box model of Toggweiler and Sarmiento (1985). The details are described in Yamamura et al. (2007) (Fig. 19). The model has five state variables: phosphate, oxygen, potential temperature, alkalinity, and DIC. Salinity is fixed to 35 practical salinity units (psu), to which phosphate, alkalinity, and DIC are normalized. Gas exchanges of $\mathrm{CO}_{2}$ and oxygen with the atmosphere are driven by the respective partial pressure gradients across the air-sea interface and a "piston velocity" of $3 \mathrm{~m} \mathrm{day}^{-1}$ (Broecker and Peng 1982). The carbonate saturation depth at the intersection of $\left[\mathrm{CO}_{3}{ }^{2-}\right]$ in the deep box and $\left[\mathrm{CO}_{3}{ }^{2-}\right]_{\text {sat }}$ (the carbonate ion concentration that is at saturation with respect to mineral calcite) is calculated from the apparent solubility product $K_{s p}$ for calcite. The production rate of organic carbon from the surface ocean is expressed as the flux of phosphate, which is assumed to occur with a stoichiometry of $\mathrm{P}: \mathrm{C}_{\text {org: }}: \mathrm{O}_{2}=1: 117: 170$ (Anderson and Sarmiento 1994). With the production rate, the global average export ratio is adjusted to $\mathrm{CaCO}_{3}: \mathrm{C}_{\text {org }}=0.1$ based on Sarmiento et al. (2002).

For initial values, which represent modern conditions, the model predicts $\left[\mathrm{CO}_{3}{ }^{2-}\right]$ of about $94 \mathrm{~mol} \mathrm{~kg}^{-1}$ and $2{ }^{\circ} \mathrm{C}$ in the deep box (Figs. 19 and 3). The calcium carbonate saturation horizon under these model conditions is located at a depth of about $3700 \mathrm{~m}$. The mid-Cretaceous is believed to be $6-12{ }^{\circ} \mathrm{C}$ warmer than today and had $2-10$ times more atmospheric $p \mathrm{CO}_{2}$ (e.g., Berner and Kothavala 2001). The model results also indicate that carbonate dissolution in the northwestern Pacific during the Albian was severe (Fig. 3). However, this is contrary to the geological observation that carbonate was apparently present at paleodepths of $\sim 1000-2000 \mathrm{~m}$ in DSDP/ ODP cores (e.g. Dean 1981). This apparent contradiction may be resolved if there were more alkalinity in the oceans during the Albian, mid-Cretaceous, than today. Global warming with high $p \mathrm{CO}_{2}$, like during the Albian, would have induced intensified hydrological cycles on the Earth's surface (e.g., Jenkyns 2010). Subsequently, this would have resulted in intensified weathering and increased the supply of nutrients and alkalinity (Eqs. 2 and 3) (Fig. 2).

To investigate the effect of a higher alkalinity content in the ocean, a set of model experiments was conducted with the same range of high latitude surface box temperatures and four-times the present atmospheric $p \mathrm{CO}_{2}$ (Fig. 19). In the late Albian, the deep-sea temperature was estimated to have been $\sim 17^{\circ} \mathrm{C}$ in the equatorial $\mathrm{Pa}$ cific (Huber et al. 2002) and $p \mathrm{CO}_{2}$ was suggested to vary 


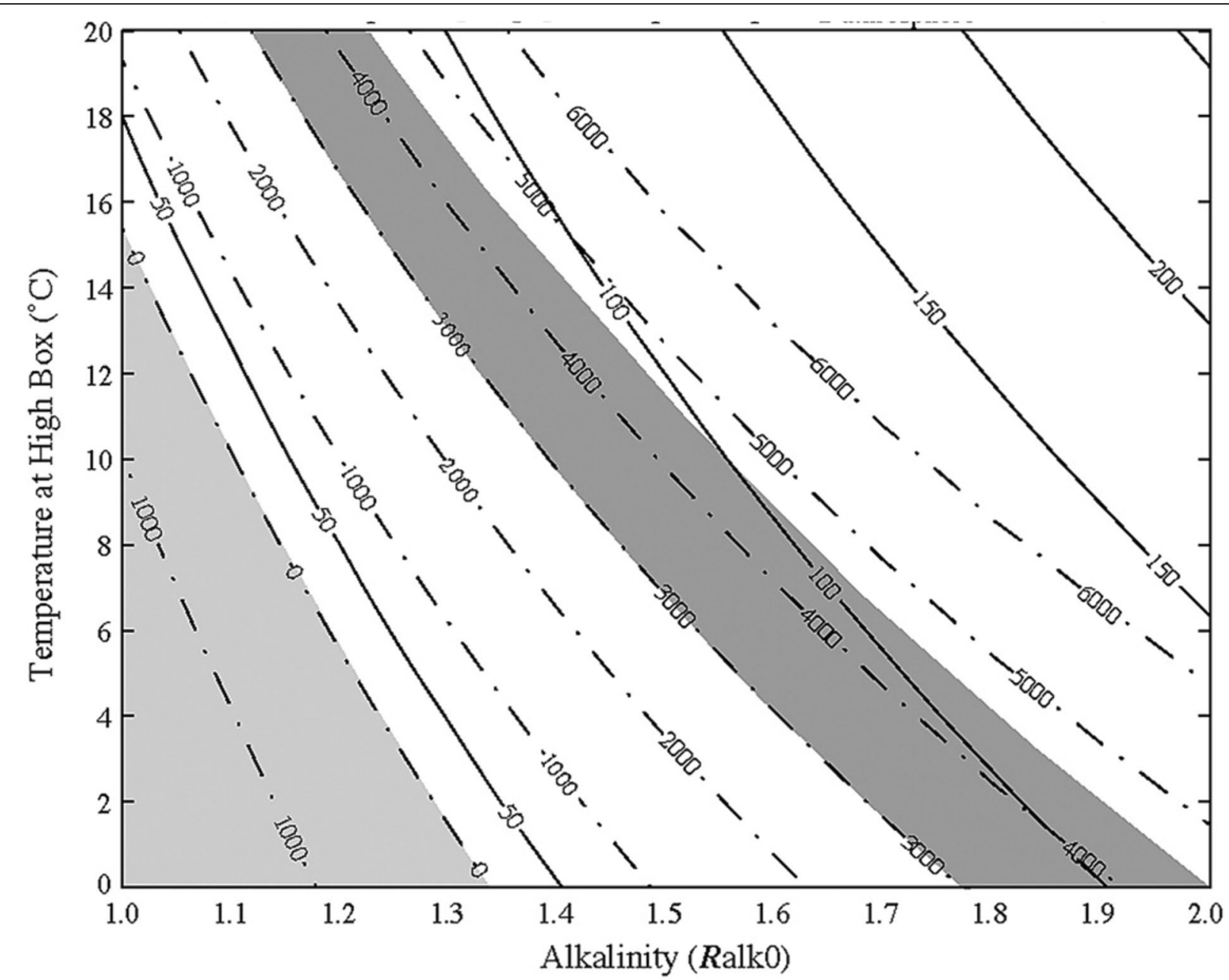

Fig. 19 Three-box model sensitivity of saturation depth and carbonate ion concentration at deep box at a high $\mathrm{CO}_{2}$ concentration (1020 ppm) (Yamamura et al. 2007). Approximately 15\% of the world ocean surface area is represented by the high-latitude box. Variable $T$ represents the large scale meridional overturning of the world ocean. Polar vertical mixing is meant to represent deep water ventilation and formation around the Antarctic continent today. Phosphate serves as the main nutrient accounting for organic carbon production. The phosphate concentration in the low-latitude surface box drives its new production by restoring the phosphate concentration to its initial value. The production rate of organic carbon from the surface ocean is expressed as the flux of phosphate, which is assumed to occur with a stoichiometry of P: $C_{\text {org }}:-O_{2}=1: 117: 170$ (Anderson and Sarmiento 1994). In this model, the new production rate at the low-latitude surface box, which is described as $\mathrm{P}_{\text {, }}$ depends on the upwelling supply flux of phosphate due to the thermohaline circulation. In the high-latitude box, the new production rate is fixed to a prescribed value since the productivity seems to be affected by factors other than nutrients. With the production rate, we adjust the global average export ratio of $\mathrm{CaCO}_{3} / \mathrm{C}_{\text {org }}$ to 0.1 based on Sarmiento et al. (2002). The solid line indicates the carbonate ion concentration ( $\mu \mathrm{mol} / \mathrm{kg}$ ) and the broken line indicates saturation depth $(\mathrm{m})$. The light-gray shading indicates the saturation depth below $0 \mathrm{~m}$. The dark shading indicates the range of the saturation depth, similar to the interglacial value

between approximately two and five times more than present-day atmospheric $p \mathrm{CO}_{2}$ (Bice et al. 2006). In such a case, the required alkalinity inventory to maintain the level of saturation depth (deep than $2000 \mathrm{~m}$ ) at the interglacial condition is greater than 1.2 times (Fig. 19). In any case, the model results indicate that under high $p \mathrm{CO}_{2}$ during the mid-Cretaceous, an increase in the oceanic inventory of alkalinity is likely necessary to preserve any carbonate on the seafloor (Fig. 2; Table 1). Otherwise, the entire ocean may be undersaturated with respect to $\mathrm{CaCO}_{3}$.

\section{Key factors inducing ocean acidification}

It is commonly believed that increasing $p \mathrm{CO}_{2}$ will induce an enhanced greenhouse effect and change seawater chemistry, resulting in future OA (Figs. 2 and 3; Table 1) (IPCC 2017). The mid-Cretaceous represents one of the warmest climate intervals during the entire Phanerozoic (termed the "hot house") due to enhanced $p \mathrm{CO}_{2}$ (e.g., Takashima et al. 2009). Actually, the mid-Cretaceous is believed to have been a much warmer environment with much higher $p \mathrm{CO}_{2}$ (e.g., Berner and Kothavala 2001). The fact that we see relatively better 


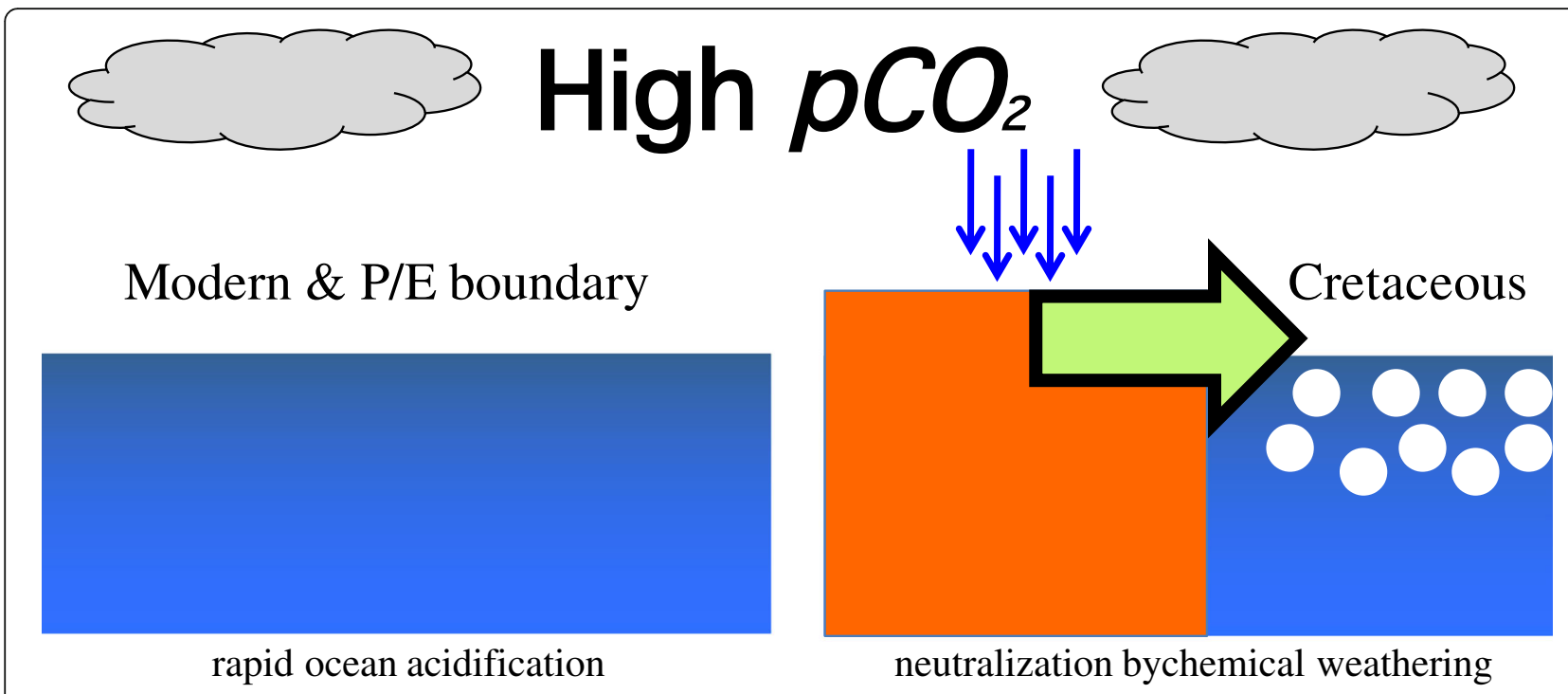

Fig. 20 Schematic diagram of ocean acidification and the buffering system in the Earth's surface system. Chemical weathering is important and acts as a neutralizing process. The level of $\mathrm{CO}_{2}$ is a secondarily important factor. The most important factor is "Changing SPEED." A natural neutralizing system such as chemical weathering cannot catch up too rapid a global environmental change under modern conditions or at the P/E boundary (Kawahata et al. 2015)

carbonate preservation in the mid-Cretaceous suggests that the ocean surface was sufficiently basic, despite higher $p \mathrm{CO}_{2}$, to allow the growth of calcifying producers. Alkalinity should have been supplied by chemical weathering on the land. A higher alkalinity inventory in the ocean is in fact expected according to an enhancement of the chemical weathering of silicate rocks, driven by $p \mathrm{CO}_{2}$ and intensified hydrological cycles on the Earth's surface (Fig. 2) (e.g., Broecker and Sanyal 1998; Cohen et al. 2004).

The biogeochemical cycle on the Earth's surface yields a buffering system for $\mathrm{pH}$ and carbonate ion change (Fig. 20). Therefore "high speed" and "high level" $p \mathrm{CO}_{2}$ are the primary and secondary factors, respectively, leading to acidification in the Earth surface's system. Too rapid a release of anthropogenic $\mathrm{CO}_{2}$ (today and at $\mathrm{P} / \mathrm{E}$ boundary) will yield severe OA in deep ocean. In combination with the high solubility of carbonate minerals (Fig. 1), benthic fauna will thus be threatened.

\section{Concluding remarks and future investigation}

In the global carbonate budget, foraminifera and corals are two major calcifiers contributing to the burial of carbonate in sediments/reefs. Our extensive review of these calcifiers suggests similar, but slightly different, responses of two representative species to ocean warming and acidification. Both calcifiers generally show negative responses to $\mathrm{OA}$ (increasing $p \mathrm{CO}_{2}$ and decreasing saturation state), although their responses are dependent upon life stage and taxa. The response of corals to heat stress is variable among species. The response of corals to acidified seawater may depend on the degree of seawater transport into the site of calcification (calcifying fluid), but this interpretation remains controversial. Foraminifera, which actively pump protons out from the site of calcification and are surrounded by a low external $\mathrm{pH}$, may deal with calcification under elevated $p \mathrm{CO}_{2}$ using an energy cost approach.

Ocean warming (i.e., higher temperature) likely induces the bleaching of symbiont-bearing marine calcifiers, including corals and foraminifera, and results in the suppression of calcification of both groups; death of the host organisms may result. However, symbiotic foraminifera appear more robust and resilient than symbiotic corals at higher temperatures. During warm periods of the Earth's history, when SSTs and deep-water temperatures exceeded those of modern oceans, foraminifera survived under extremely warm, high $p \mathrm{CO}_{2}$, and dysoxic conditions. However, corals and living reefs never existed during these warm periods, known as the reef gaps (Veron 2008). Therefore, benthic foraminifera seemed more adaptive and robust than corals to ocean warming and acidification over the Earth's history; they will likely remain so in the future. On the other hand, during a possible $\mathrm{OA}$ event at $65 \mathrm{Ma}$ at the end Cretaceous mass extinction, all remaining ammonites and belemnites became extinct, as did a high percentage of bivalves, gastropods, and echinoids, and almost all planktic foraminifera. Scleractinian corals appear to have just barely survived and 1 (the Faviidae) retained 6 of its original 16 genera; the others survived with only 1 or 2 . Therefore, in order to pursue the issue of adaption and 
robustness, it is required to further understand the mechanisms underlying variations in sensitivity to heat stress and acidified seawater for both corals and foraminifera.

Since the $p \mathrm{CO}_{2}$ in the atmosphere is currently increasing, $p \mathrm{CO}_{2}$ and DIC in seawater are increasing, while $\mathrm{pH}$ and the saturation state of carbonate minerals are decreasing without any change in total alkalinity. However, over the long-term, it is well known that alkalinity has fluctuated largely in the Earth's surface environment. Therefore, it is important to quantitatively reconstruct alkalinity, which is another key factor determining the saturation state of carbonate minerals.

\section{Summary}

Global warming and OA are often referred to as the "evil twins" of climate change due to enhanced $p \mathrm{CO}_{2}$. Both will yield severe threats to marine calcifiers in the near future (Fig. 1)

1. $\mathrm{CO}_{2}$ dissolution into seawater increases DIC and $p \mathrm{CO}_{2}$ and decreases $\mathrm{pH}$, with no change to total alkalinity. While OA may progress ubiquitously, the corresponding changes in $\mathrm{pH}$ and $p \mathrm{CO}_{2}$ vary locally. Since $p \mathrm{CO}_{2}$ is sensitive to temperature $(\sim 4 \%$ increase per $\left.1{ }^{\circ} \mathrm{C}\right), \mathrm{OA}$ is more critical in the polar and highlatitude regions, as compared with temperate and tropical regions. In addition, older deep-water has enhanced acidity owing to the addition of $\mathrm{CO}_{2}$ via the degradation of $\mathrm{OM}$, which promotes carbonate dissolution via a synergistic effect with high pressure.

2. Anthropogenic $\mathrm{CO}_{2}$-driven $\mathrm{OA}$ will pose a severe threat to marine calcifying organisms because the calcification rates of organisms generally decrease in acidified seawater. However, some opposite responses of reef-dwelling larger benthic foraminifera are reported.

3. In the case of the coral calcification response of Aropora digitifera to acidified seawater, calcification tended to decrease according to the increase of $p \mathrm{CO}_{2}$ in both aposymbiotic and symbiotic polyps, although the calcification of adult branches was not reduced markedly in higher $p \mathrm{CO}_{2}$ conditions. This suggests that $\mathrm{OA}$ response may depend upon life cycle stage.

4. As exemplified by reef-building corals and reef-dwelling larger benthic foraminifera, photosymbiosis is regarded as an adaptive ecology for living in warm, oligotrophic, and well-lit oceans. Bleaching is likely a global threat to marine symbiont calcifying organisms, especially at high temperature and enhanced light intensity.

5. Based upon $\mathrm{Ca}$ isotope measurements of coral skeletons, the transport path of $\mathrm{Ca}^{2+}$ and the extent of its activity would predominantly control the carbonate precipitation rate. Visualization of the extracellular $\mathrm{pH}$ distribution shows that proton pumping produces a high internal $\mathrm{pH}$ and large internal-external $\mathrm{pH}$ gap associated with foraminiferal calcification.

6. X-ray micro-computed tomography, which can estimate shell density, indicates that the dissolution of Globigerina bulloides shells begins at the central area of the shell, whereas the outer calcite layer, with a euhedral crystalline structure, is resistant to dissolution.

7. Alkalinity, another key factor controlling OA, has a much longer residence time. The "high speed" and "high level" of $p \mathrm{CO}_{2}$ are the primary and secondary factors, respectively, leading to severe OA in the Earth surface's system. Too rapid a release of anthropogenic $\mathrm{CO}_{2}$ (today and at $\mathrm{P} / \mathrm{E}$ boundary) would bring severe OA, even in the deep ocean.

\section{Abbreviations}

CCD: Carbonate compensation depth; DIC: Dissolved inorganic carbon; kyr: Kilo years; Ma: Megaannum (one million years); OA: Ocean acidification; OM: Organic matter; $\mathrm{PCO}_{2}$ : Partial pressure of $\mathrm{CO}_{2}$; SST: Sea surface temperature; $\Omega_{\text {arag }}$ : Aragonite saturation state; $\Omega_{\text {cal }}$ : Calcite saturation state

\section{Acknowledgements}

This research was partly supported by the Japan Society for the Promotion of Science Grants-in-Aid for Scientific Research (A) to H. Kawahata (15H02139).

\section{Funding}

This work was supported by JSPS KAKENHI Grant Numbers 22224009 ,

$15 \mathrm{H} 02139,15 \mathrm{H} 02813,18 \mathrm{H} 03366$, and $18 \mathrm{~K} 18793$.

Availability of data and materials

Please contact author for data requests. All authors will share data and materials.

\section{Authors' contributions}

HK proposed and designed the study. KF described the part of the manuscript, including the topic on the bleaching in algal symbiont-bearing large benthic foraminifera. Al described the part of the manuscript, including the topic on the bleaching in corals. MI described the part of the manuscript, including the topic on biomineralization of corals based on geochemical analyses. SI described the part of the manuscript, including the topic on deep-sea carbonate dissolution and progressive foraminiferal shell dissolution. AK described the part of the manuscript, including the topic on Response of foraminifera against ocean acidification. AM described the figures. TM described the part of the manuscript, including the topic on long-term neutralizing process against enhanced $p \mathrm{CO}_{2}$. KM described the part of the manuscript, including the topic on the extreme warmth in the Cretaceous greenhouse system. HT described the part of the manuscript, including the topic on warmth in the Middle Eocene Climatic Optimum (MECO) event and foraminiferal photosymbiosis. $T$ described the part of the manuscript, including the topic on biomineralization of foraminifera. TY described the part of the manuscript, including the topic on characteristics of biotic and abiotic carbonate minerals. AS described the part of the manuscript, including the topic on general feature of marine carbonate system. All authors interpreted the data, read, and approved the final manuscript.

\section{Authors' information}

No special information for each author.

\section{Competing interests}

The authors declare that they have no competing interests.

\section{Publisher's Note}

Springer Nature remains neutral with regard to jurisdictional claims in published maps and institutional affiliations. 


\section{Author details}

'Atmosphere and Ocean Research Institute, The University of Tokyo, 5-1-5 Kashiwanoha, Kashiwa, Chiba 277-8564, Japan. ${ }^{2}$ Geological Survey of Japan, National Institute of Advanced Industrial Science and Technology (AIST), Higashi 1-1-1, Tsukuba, Ibaraki 305-8567, Japan. ${ }^{3}$ Department of Physics and Earth Sciences, Faculty of Science and Tropical Biosphere Research Center, University of the Ryukyus, 1 Senbaru Nishiharacho, Okinawa 903-0213, Japan. ${ }^{4}$ Department of Earth and Planetary Science, Faculty of Science, Okayama University, 3-1-1 Tsushima-naka, Okayama 700-8530, Japan. ${ }^{5}$ Japan Agency for Marine-Earth Science and Technology (JAMSTEC), 2-15, Natsushima, Yokosuka 237-0061, Japan. ${ }^{6}$ The Center for Academic Resources and Archives, Tohoku University Museum, Tohoku University, 6-3 Aramaki-Aza Aoba, Aoba-ku, Sendai, Miyagi 980-8578, Japan. ${ }^{7}$ Department of Forest Soils, Forestry and Forest Products Research Institute, 1 Matsunosato, Tsukuba, Ibaraki 305-8687, Japan. ${ }^{8}$ Department of Earth Sciences, School of Education, Waseda University, 1-6-1 Nishiwaseda, Shinjuku, Tokyo 169-8050, Japan.

Received: 4 March 2018 Accepted: 8 November 2018

Published online: 17 January 2019

\section{References}

Albright R, Mason B, Langdon C (2008) Effect of aragonite saturation state on settlement and post-settlement growth of Porites astreoides larvae. Coral Reefs 27:485-490

Al-Horani FA, Al-Moghrabi SM, de Beer D (2003) The mechanism of calcification and its relation to photosynthesis and respiration in the scleractinian coral Galaxea fascicularis. Mar Biol Berlin 142:419-426

Allemand D, Ferrier-Pagés C, Furla P, Houlbréque F, Puverel S, Reynaud S, Tambutté É, Tambutté S, Zoccola D (2004) Biomineralisation in reef-building corals: from molecular mechanisms to environmental control. Comptes Rendus Palevol 3:453-467. https://doi.org/10.1016/j.crpv.2004.07.011

Anderson LA, Sarmiento JL (1994) Redfield ratios of remineralization determined by nutrient data analysis. Glob Biogeochem Cycles 8:65-80

Anthony KRN, Kline DI, Diaz-Pulido G, Dove S, Hoegh-Guldberg O (2008) Ocean acidification causes bleaching and productivity loss in coral reef builders. Proc Nat Acad Sci U S A 105:17442-17446. https://doi.org/10.1073/pnas. 0804478105

Archer DE (1996) A data driven model of the global calcite lysocline. Glob Biogeochem Cycles 10:511-526

Aze T, Ezard THG, Purvis A, Coxall HK, Stewart DRM, Wade BS, Pearson PN (2011) A phylogeny of Cenozoic macroperforate planktic foraminifera from fossil data. Biol Rev 86:900-927

Baird AH, Bhagooli R, Ralph PJ, Takahashi S (2009) Coral bleaching: the role of the host. Trends Ecol Evol 24:16-20. https://doi.org/10.1016/j.tree.2008.09.005

Bandy OL (1954) Aragonite tests among foraminifera. J Sediment Res 24:60-61

Barker S, Elderfield H (2002) Foraminiferal calcification response to glacialinterglacial changes in atmospheric $\mathrm{CO}_{2}$. Science 297:833-836

Bassinot FC, Mélières F, Gehlen M, Levi C, Labeyrie L (2004) Crystallinity of foraminifera shells: a proxy to recon- struct past botto $\mathrm{m}$ water $\mathrm{CO}_{3}{ }^{=}$changes? Geochem Geophys Geosystems 5:Q08D10. https://doi.org/10.1029/2003GC000668

Bé AWH, Anderson OR, Faber WW Jr, Caron DA (1983) Sequence of morphological and cytoplasmic changes during gametogenesis in the planktonic foraminifer Globigerinoides sacculifer (Brady). Micropaleontol 29:310-325

Bé AWH, Hemleben C (1970) Calcification in a living planktonic foraminifer, Globigerinoides sacculifer (Brady). Neues Jahrb Geol Paläontol 134:221-234

Beaufort L, Grelaud M (2017) A 2700-year record of ENSO and PDO variability from the Californian margin based on coccolithophore assemblages and calcification. Prog Earth Planet Sci 4:5. https://doi.org/10.1186/540645-017-0123-z

Bemis BE, Spero HJ, Bijima J, Lea DW (1998) Reevaluation of the oxygen isotopic composition of planktonic foraminifera: experimental results and revised paleotemperature equations. Paleoceanogra 13(2):150-160

Bentov S, Brownlee C, Erez I (2009) The role of seawater endocytosis in the biomineralization process in calcareous foraminifera. Proc Natl Acad Sci U S A 106:21500-21504

Bentov S, Erez J (2005) Novel observations on biomineralization processes in foraminifera and implications for $\mathrm{mg} / \mathrm{ca}$ ratio in the shells. Geology 33:841

Bentov S, Erez J (2006) Impact of biomineralization processes on the Mg content of foraminiferal shells: a biological perspective. Geochem Geophys Geosystems 7:Q01P08

Berger WH (1968) Planktonic foraminifera: selective solution and paleoclimatic interpretation. Deep-Sea Res Oceanogr Abstr 15(1):31-43
Berner RA (1992) Weathering, plants, and the long-term carbon cycle. Geochim Cosmochim Acta 56:3225-3231. https:/doi.org/10.1016/0016-7037(92)90300-8

Berner RA, Kothavala Z (2001) Geocarb III: a revised model of atmospheric $\mathrm{CO}_{2}$ over Phanerozoic time. Am J Sci 301:182-204

Bice KL, Birgel D, Meyers PA, Dahl KA, Hinrichs KU, Norris RD (2006) A multiple proxy and model study of cretaceous upper ocean temperatures and atmospheric $\mathrm{CO}_{2}$ concentrations. Paleoceanogra 21:PA2002

Bice KL, Huber BT, Norris RD (2003) Extreme polar warmth during the cretaceous greenhouse? Paradox of the late Turonian 8180 record at Deep Sea drilling project site 511. Paleoceanogra 18:1031

Bickle MJ, Bunbury J, Chapman HJ, Harris NBW, Fairchild IJ, Ahmad T (2003) Fluxes of Sr into the headwaters of the Ganges. Geochim Cosmochim Acta 67:2567-2584. https://doi.org/10.1016/S0016-7037(03)00029-2

Bickle MJ, Harris NBW, Bunbury JM, Chapman HJ, Fairchild IJ, Ahmad T (2001) Controls on the ${ }^{87} \mathrm{Sr} /{ }^{86} \mathrm{Sr}$ ratios of carbonates in the Garhwal Himalaya, headwaters of the Ganges. J Geol 109:737-753. https://doi.org/10.1086/323192

Bijl PK, Houben AJP, Schouten S, Bohaty SM, Sluiis A, Reichart G-J, Sinninghe Damsté JS, Brinkhuis H (2010) Transient middle Eocene atmospheric $\mathrm{CO}_{2}$ and temperature variations. Science 330:819-821

Bijma J, Spero HJ, Lea DW (1999) Reassessing foraminiferal stable isotope geochemistry: impact of the oceanic carbonate system (experimental results). In: Fischer G, Wefer $\mathrm{G}$ (eds) Use of proxies in paleoceanography: examples from the South Atlantic. Springer-Verlag, New York, pp 489-512

Bijma J, Hönisch B, Zeebe RE (2002) Impact of the ocean carbonatechemistry on living foraminiferal shell weight: Comment on "Carbonateion concentration in glacial-age deep waters of the Caribbean Sea" by Broecker WS, Clark E, Geochem Geophys Geosyst 3:1064. https://doi.org/10.1029/2002GC000388.

Birch HS, Coxall HK, Pearson PN (2012) Evolutionary ecology of early Paleocene planktonic foraminifera: size, depth habitat and symbiosis. Paleobiol 38:374-390

Böhm F, Gussone N, Eisenhauer A, Dullo WC, Reynaud S, Paytan A (2006) Calcium isotope fractionation in modern Scleractinian corals. Geochim Cosmochim Acta 70:4452-4462

Bornemann A, Norris RD (2007) Size-related stable isotope changes in Late Cretaceous planktic foraminifera: implications for paleoecology and photosymbiosis. Mar Micropaleontol 65:32-42

Bornemann A, Norris RD, Friedrich O, Bechmann B, Schouten S, Sinninghe Damsté JS, Vogel J, Hofmann P, Wagner T (2008) Isotopic evidence for glaciation during the Cretacesous supergreenhouse. Science 319:189-192

Brady PV (1991) The effect of silicate weathering on global temperature and atmospheric $\mathrm{CO}_{2}$. J Geophys Res 96:18101-18106

Bralower TJ, Thomas DJ, Zachos JC, Hirschmann MM, Röhl U, Sigurdsson H, Thomas E, Whitney DL (1997) High-resolution records of the late Paleocene thermal maximum and circum-Caribbean volcanism: is there a causal link? Geology 25:963-966

Branson O, Redfern SAT, Tyliszczak T, Sadekov A, Langer G, Kimoto K, Elderfield H (2013) The coordination of Mg in foraminiferal calcite. Earth Planet Sci Lett 383:134-141. https://doi.org/10.1016/j.epsl.2013.09.037

Broecker WS, Clark E (2001) An evaluation of Lohmann's foraminifera weight dissolution index. Paleoceanogra 16:531-534

Broecker WS, Clark E (2002) Carbonate ion concentration in glacial-age deep waters of the Caribbean Sea. Geochem Geophys Geosystems 3:1-14

Broecker WS, Peng T-H (1982) Tracers in the sea. Lamont-Doherty Geological Observatory, Palisades, NY

Broecker WS, Sanyal A (1998) Does atmospheric $\mathrm{CO}_{2}$ police the rate of chemical weathering? Glob Biogeochem Cycles 12:403-408

Broecker WS, Takahashi T (1977) Neutralization of fossil fuel $\mathrm{CO}_{2}$ by marine calcium carbonate. In: the fate of fossil fuel $\mathrm{CO}_{2}$ in the oceans. In: Andersen NR, Malahoff A (eds) Marine science, 6. Plenum Press, New York, pp 213-242

Brown BE (1997) Coral bleaching: causes and consequences. Coral Reefs 16(Suppl):S129-S138

Brune S, Williams SE, Müller RD (2017) Potential links between continental rifting, CO2 degassing and climate change through time. Nat Geosci 10:941-946

Bunkley-Williams G, Williams EH (1990) Global assault on coral reefs. Nat Hist 4:47-54

Cai W-J, Hu X, Huang W-J, Murrell MC, Lehrter JC, Lohrenz SE, Chou W-C, Zhai W, Hollibaugh JT, Wang Y, Zhao P, Guo X, Gundersen K, Dai M, Gong G-C (2011) Acidification of subsurface coastal waters enhanced by eutrophication. Nat Geosci 4:766-770. https://doi.org/10.1038/ngeo1297

Cai W-J, Ma Y, Hopkinson BM, Grottoli AG, Warner ME, Ding Q, Hu X, Yuan X, Schoepf V, Xu H, Han C, Melman TF, Hoadley KD, Pettay DT, Matsui Y, Baumann JH, Levas S, Ying Y, Wang Y (2016) Microelectrode characterization of coral daytime interior pH and carbonate chemistry. Nat Commun 7:11144 
Caldeira K, Wickett ME (2003) Anthropogenic carbon and ocean pH. Nature 423:365 Cantin NE, Cohen AL, Karnauskas KB, Tarrant AM, McCorkle DC (2010) Ocean warming slows coral growth in the central Red Sea. Science 329:322-325. https://doi.org/10.1126/science.1190182

Carafoli E (2004) Calcium signaling: a historical account. Biol Res 37:497-505

Catubig NR, Archer DE, Francois R, deMenocal P, Howard W, Yu EF (1998) Global deep-sea burial rate of calcium carbonate during the last glacial maximum. Paleoceanogr 13:298-310

Chauvin A, Denis V, Cuet P (2011) Is the response of coral calcification to seawater acidification related to nutrient loading? Coral Reefs 30:911-923. https://doi.org/10.1007/s00338-011-0786-7

Clift PD (2017) Cenozoic sedimentary records of climate-tectonic coupling in the Western Himalaya. Prog Earth Planet Sci 4:39. https://doi.org/10.1186/s40645017-0151-8

Cohen A, McConnaughey T (2003) Geochemical perspectives on coral mineralization. Rev Mineral Geochem 54:151-187. https:/doi.org/10.2113/0540151

Cohen AS, Coe AL, Harding SM, Schwark L (2004) Osumium isotope evidence for the regulation of atmospheric $\mathrm{CO}_{2}$ by continental weathering. Geology 32: $157-160$

Cole JJ, Prairie YT, Caraco NF, McDowell WH, Tranvik L, Striegl RG, Duarte CM, Kortelainen P, Downing JA, Middelburg JJ, Melack J (2007) Plumbing the global carbon cycle: integrating inland waters into the terrestrial carbon budget. Ecosystems 10:172-185. https://doi.org/10.1007/s10021-006-9013-8

Comeau S, Carpenter RC, Edmunds PJ (2013) Coral reef calcifiers buffer their response to ocean acidification using both bicarbonate and carbonate. Proc Royal Soc B 280:20122374. https://doi.org/10.1098/rspb.2012.2374

Comeau S, Edmunds PJ, Spindel NB, Carpenter RC (2014) Fast coral reef calcifiers are more sensitive to ocean acidification in short-term laboratory incubations. Limnol Oceanogr 59:1081-1091. https://doi.org/10.4319//o.2014.59.3.1081

Cuif JP, Dauphin Y, Sorauf J (2011) Biominerals and fossils through time. Cambridge University Press, Cambridge

Cusack M, Freer A (2008) Biomineralization: elemental and organic influence in carbonate systems. Chem Rev 108:4433-4454. https://doi.org/10.1021/ cr078270o

Cyronak T, Andersson AJ, Langdon C, Albright R, Bates NR, Caldeira K, Carlton R, Corredor JE, Dunbar RB, Enochs I, Erez J, Eyre BD, Gattuso J-P, Gledhill D, Kayanne H, Kline DI, Koweek DA, Lantz C, Lazar B, Manzello D, McMahon A, Meléndez M, Page H, Santos IR, Schulz KG, Shaw E, Silverman J, Suzuki A, Teneva L, Watanabe A, Yamamoto S (2018) Taking the metabolic pulse of the world's coral reefs. PLoS One 13:e0190872. https://doi.org/10.1371/ journal.pone.0190872

Dado JMB, Takahashi HG (2017) Potential impact of sea surface temperature on rainfall over the western Philippines. Prog Earth Planet Sci 4:23. https://doi. org/10.1186/s40645-017-0137-6

Davis KJ, Dove PM, De Yoreo JJ (2000) The role of $\mathrm{Mg}^{2+}$ as an impurity in calcite growth. Science 290:1134-1137

De Groot K, Duyvis E (1966) Crystal form of precipitated calcium carbonate as influenced by adsorbed magnesium ions. Nature 212:183-184

de Nooijer L, Langer G, Nehrke G, Bijma J (2009a) Physiological controls on seawater uptake and calcification in the benthic foraminifer Ammonia tepida. Biogeosci 6:2669-2675

de Nooijer LJ, Spero HJ, Erez J, Bijma J, Reichart GJ (2014) Biomineralization in perforate foraminifera. Earth-Sci Rev 135:48-58

de Nooijer LJ, Toyofuku T, Kitazato H (2009b) Foraminifera promote calcification by elevating their intracellular pH. Proc Natl Acad Sci U S A 106:15374-15378

de Nooijer L, Toyofuku T, Oguri K, Nomaki H, Kitazato H (2008) Intracellular pH distribution in foraminifera determined by the fluorescent probe HPTS. Limnol Oceanogra Methods 6:610-618

de Villers S (2005) Foraminiferal shell-weight evidence for sedimentary calcite dissolution above the lysocline. Deep-Sea Res I 52:671-668

de Villiers S (2003) A 425 ka record of foraminiferal shell weight variability in the western equatorial Pacific. Paleoceanogra 18:1080

de Villiers S (2004) Occupation of an ecological niche as the fundamental control on the shell-weight of calcifying planktonic foraminifera. Mar Biol 144:45-50

De'ath G, Lough JM, Fabricius KE (2009) Declining coral calcification on the Great Barrier Reef. Science 323:116-119. https://doi.org/10.1126/science.1165283

Dean WE (1981) Calcium carbonate and organic carbon in samples from deep sea drilling project sites 463, 464, 465, and 466. Initial Rep Deep Sea Drilling Proj 62:869-876

Deffeyes KS (1965) Carbonate equilibria: a graphic and algebraic approach. Limnol Oceanogra 10:412-426
D'Hondt S, Arthur MA (1996) Late Cretaceous oceans and the cool tropic paradox. Science 271:1838-1841

Dickens GR, Castillo MM, Walker JGC (1997) A blast of gas in the latest Paleocene: simulating first-order effects of massive dissociation of oceanic methane hydrate. Geology 25:259-262

Doo SS, Fujita K, Byrne M, Uthicke S (2014) Fate of calcifying tropical symbiontbearing large benthic foraminifera: living sands in a changing ocean. Biol Bull 226:169-186

Edgar KM, Bohaty SM, Gibbs SJ, Sexton PF, Norris RD, Wilson PA (2013) Symbiont 'bleaching' in planktic foraminifera during the middle Eocene climatic optimum. Geology 41:15-18

Elderfield H, Bertram CJ, Erez J (1996) A biomineralization model for the incorporation of trace elements into foraminiferal calcium carbonate. Earth Planet Sci Let 142:409-423

Erez J (2003) The source of ions for biomineralization in foraminifera and their implications for Paleoceanographic proxies. Rev Mineral Geochem 54:115-149

Ernst SR, Guasti E, Dupuis C, Speijer RP (2006) Environmental perturbation in the southern Tethys across the Paleocene/Eocene boundary (Dababiya, Egypt): foraminiferal and clay mineral records. Mari Micropaleontol 60:89-111

Fenton M, Geiselhart S, Rohling EJ, Hemleben C (2000) Aplanktonic zones in the Red Sea. Mar Micropaleontol 40:277-294

Finch AA, Allison N (2008) Mg structural state in coral aragonite and implications for the paleoenvironmental proxy. Geophys Res Lett 35:L08704. https://doi. org/10.1029/2008gl033543

Flako-Zaritsky S, Almogi-Labin A, Schilman B, Rosenfeld A, Benjamini C (2011) The environmental setting and microfauna of the oligohaline Timsah pond, Israel: the last remnant of the Kabara swamps. Mar Micropaleontol 80:74-88

Forster A, Schouten S, Moriya K, Wilson PA, Damste JSS (2007) Tropical warming and intermittent cooling during the Cenomanian/Turonian oceanic anoxic event 2: sea surface temperature records from the equatorial Atlantic. Paleoceanogra 22:PA1219

France-Lanord C, Derry LA (1997) Organic carbon burial forcing of the carbon cycle from Himalayan erosion. Nature 390:65-67. https:/doi.org/10.1038/36324

Friedrich O, Erbacher J, Moriya K, Wilson PA, Kuhnert H (2008) Warm saline intermediate waters in the Cretaceous tropical Atlantic Ocean. Nat Geosci 1: 453-457

Fujita K, Hikami M, Suzuki A, Kuroyanagi A, Sakai K, Kawahata H, Nojiri Y (2011) Effects of ocean acidification on calcification of symbiont-bearing reef foraminifers. Biogeosci 8:2089-2098

Fujita K, Okai T, Hosono T (2014) Oxygen metabolic responses of three species of large benthic foraminifers with algal symbionts to temperature stress. PLoS One 9:e90304

Gagnon AC, Adkins JF, Erez J (2012) Seawater transport during coral biomineralization. Earth Planet Scie Lett 329-330:150-161

Gaillardet J, Dupré B, Louvat P, Allègre CJ (1999) Global silicate weathering and $\mathrm{CO}_{2}$ consumption rates deduced from the chemistry of large rivers. Chem Geol 159:3-30. https://doi.org/10.1016/S0009-2541(99)00031-5

Gangsto R, Gehlen M, Schneider B, Bopp L, Aumont O, Joos F (2008) Modeling the marine aragonite cycle: changes under rising carbon dioxide and its role in shallow water $\mathrm{CaCO}_{3}$ dissolution. Biogeosci 5:1057-1072

Gattuso JP, Allemand D, Frankignoulle M (1999) Photosynthesis and calcification at cellular, organismal and community levels in coral reefs: a review of interactions and control by carbonate chemistry. Amer Zool 39:160-183. https://doi.org/10.1093/icb/39.1.160

Gattuso J-P, Frankignoulle M, Bourge I, Romaine S, Buddemeier RW (1998) Effect of calcium carbonate saturation of seawater on coral calcification. Glob Planet Chang 18:37-46

Glas MS, Langer G, Keul N (2012) Calcification acidifies the microenvironment of a benthic foraminifer (Ammonia sp.). J Exp Mar Biol Ecol 424-425:53-58

Gonzalez-Mora B, Sierro FJ, Flores JA (2008) Controls of shell calcification in planktonic foraminifers. Quat Sci Rev 27:956-961

Goswami BN, Venugopal V, Sengupta D, Madhusoodanan MS, Xavier PK (2006) Increasing trend of extreme rain events over India in a warming environment. Science 314:1442-1445. https://doi.org/10.1126/science.1132027

Grønlund H, Hansen HJ (1976) Scanning electron microscopy of some recent and fossil nodosariid foraminifera. Bull Geol Soc Den 25:121-134

Gussone N, Langer G, Thoms S, Nehrke G, Eisenhauer A, Riebesell U, Wefer G (2006) Cellular calcium pathways and isotope fractionation in Emiliania huxleyi. Geology 34:625-628c

Hallock P (2000) Symbiont-bearing foraminifera: harbingers of global change? Micropaleontol 46:95-104 
Hallock P, Willams DE, Fisher EM, Toler SK (2006) Bleaching in reef-dwelling foraminifers: implications for reef monitoring and risk assessment. Anuário do Instituto de Geociências UFRJ 29:108-128

Hartmann J, Jansen N, Dürr HH, Kempe S, Köhler P (2009) Global $\mathrm{CO}_{2}$ consumption by chemical weathering: what is the contribution of highly active weathering regions? Glob Planet Change 69:185-194. https://doi.org/ 10.1016/j.gloplacha.2009.07.007

Hashimoto S, Carvalhais N, Ito A, Migliavacca M, Nishina K, Reichstein M (2015) Global spatiotemporal distribution of soil respiration modeled using a global database. Biogeosci 12:4121-4132. https://doi.org/10.5194/bg-12-4121-2015

Hecht H, Oguchi T (2017) Global evaluation of erosion rates in relation to tectonics. Prog Earth Planet Sci 4:40. https://doi.org/10.1186/s40645-017-0156-3

Hikami M, Ushie H, Irie T, Fujita K, Kuroyanagi A, Sakai K, Nojiri Y, Suzuki A, Kawahata H (2011) Contrasting calcification responses to ocean acidification between two reef foraminifers harboring different algal symbionts. Geophys Res Lett 38:L19601. https://doi.org/10.1029/2011GL048501

Hippler D, Schmitt AD, Gussone N, Heuser A, Stille P, Eisenhauer A, Nägler TF (2003) Calcium isotopic composition of various reference materials and seawater. Geostand Newslett 27:13-19

Hoegh-Guldberg O (1999) Climate change, coral bleaching and the future of the world's coral reefs. Mar Fresh Res 50:839-866. https:/doi.org/10.1071/MF99078

Hoegh-Guldberg O, Mumby PJ, Hooten AJ, Steneck RS, Greenfield P, Gomez E, Harvell CD, Sale PF, Edwards AJ, Caldeira K, Knowlton N, Eakin CM, IglesiasPrieto R, Muthiga N, Bradbury RH, Dubi A, Hatziolos ME (2007) Coral reefs under rapid climate change and ocean acidification. Science 318:1737-1742

Hohn S, Merico A (2012) Modelling coral polyp calcification in relation to ocean acidification. Biogeosci 9:4441-4454. https://doi.org/10.5194/bg-9-4441-2012

Hohn S, Merico A (2015) Quantifying the relative importance of transcellular and paracellular ion transports to coral polyp calcification. Front Earth Sci 2:37. https://doi.org/10.3389/feart.2014.0037

Holcomb M, McCorkle DC, Cohen AL (2010) Long-term effects of nutrient and CO2 enrichment on the temperate coral Astrangia poculata (Ellis and Solander, 1786). J Exp Mar Biol Ecol 386:27-33. https://doi.org/10.1016/j. jembe.2010.02.007

Huber BT, Leckie RM, Norris RD, Bralower TJ, CoBabe E (1999) Foraminiferal asseblage and stable isotopic change across the Cenomanian-Turonian b oundary in the subtropical North Atlantic. J Foraminiferal Res 29:392-417

Huber BT, Norris RD, MacLeod KG (2002) Deep-sea paleotemperature record of extreme warmth during the Cretaceous. Geology 30:123-126

Hughes TP, Tanner JE (2000) Recruitment failure, life histories, and long-term decline of Caribbean corals. Ecology 81:2250-2263

Iglesias-Prieto R, Matta JL, Robins WA, Trench RK (1992) Photosynthetic response to elevated temperature in the symbiotic dinoflagellate Symbiodinium microadriaticum in culture. Proc Natl Acad Sci U S A 89:10302-10305

Iglesias-Rodriguez MD, Brown CW, Doney SC, Kleypas J, Kolber D, Kolber Z, Hayes PK, Falkowski PG (2002) Representing key phytoplankton functional groups in ocean carbon cycle models: Coccolithophorids. Glob Biogeochem Cycles 16. https://doi.org/10.1029/2001GB001454

Iguchi A, Kumagai NH, Nakamura T, Suzuki A, Sakai K (2014) Responses of calcification of massive and encrusting corals to past, present, and nearfuture ocean carbon dioxide concentrations. Mar Pollut Bull 89:348-355. https://doi.org/10.1016/j.marpolbul.2014.09.037

Iguchi A, Ozaki S, Nakamura T, Inoue M, Tanaka Y, Suzuki A, Kawahata H, Sakai K (2012) Effects of acidified seawater on coral calcification and symbiotic algae on the massive coral Porites australiensis. Mar Env Res 73:32-36. https://doi. org/10.1016/j.marenvres.2011.10.008

Inoue M, Gussone N, Koga Y, Iwase A, Suzuki A, Sakai K, Kawahata H (2015) Controlling factors of $\mathrm{Ca}$ isotope fractionation in scleractinian corals evaluated by temperature, $\mathrm{pH}$ and light controlled culture experiments. Geochim Cosmochim Acta 167:80-92

Inoue M, Shinmen K, Kawahata H, Nakamura T, Tanaka Y, Kato A, Shinzato C, Iguchi A, Kan H, Suzuki A, Sakai K (2012) Estimate of calcification responses to therma and freshening stresses based on culture experiments with symbiotic and aposymbiotic primary polyps of a coral, Acropora digitifera. Glob Planet Change 92-93:1-7. https://doi.org/10.1016/j.gloplacha.2012.05.001

Inoue M, Suwa R, Suzuki A, Sakai K, Kawahata H (2011) Effects of seawater pH on growth and skeletal U/Ca ratios of Acropora digitifera coral polyps. Geophys Res Lett 38:L12809. https://doi.org/10.1029/2011GL047786

IPCC (2013) Summary for policymakers. In: Stocker TF, Qin D, Plattner G-K, Tignor M, Allen SK, Boschung J, Nauels A, Xia Y, Bex V, Midgley PM (eds) Climate change 2013: the physical science basis contribution of working group I to the fifth assessment report of the intergovernmental panel on climate change. Cambridge University Press, Cambridge, United Kingdom and New York, NY, USA

IPCC (2017) https://royalsociety.org/topics-policy/publications/2017/climate-updates/. Accessed 5 Dec 2018

Ishimura T, Tsunogai U, Gamo T (2004) Stable carbon and oxygen isotopic determination of sub-microgram quantities of $\mathrm{CaCO}_{3}$ to analyze individual foraminiferal shells. Rapid Commun Mass Spectrom 18:2883-2888

Ishimura T, Tsunogai U, Nakagawa F (2008) Grain-scale heterogeneities in the stable carbon and oxygen isotopic compositions of the international standard calcite materials (NBS 19, NBS 18, IAEA-CO-1, and IAEA-CO-8). Rapid Commun Mass Spectrom 22:1925-1932

Itaki T (2016) Transitional changes in microfossil assemblages in the Japan Sea from the Late Pliocene to Early Pleistocene related to global climatic and local tectonic events. Prog Earth Planet Sci 3:11. https://doi.org/10.1186/ s40645-016-0087-4

Iwasaki S, Kimoto K, Sasaki O, Kano H, Honda MC, Okazaki Y (2015) Observation of the dissolution process of Globigerina bulloides tests (planktic foraminifera) by X-ray microcomputed tomography. Paleoceanography 30:317-331. https://doi.org/10.1002/2014pa002639

Jenkyns HC (2010) Geochemistry of oceanic anoxic events. Geochem Geophys Geosystems 11:Q03004. https://doi.org/10.1029/2009GC002788

Johnstone HJH, Schulz M, Yu J, Elderfield H (2010) Inside story: an X-ray computed tomography method for assessing dissolution in the tests of planktonic foraminifera. Mar Micropaleontol 77:58-70

Jokiel PL (2011) Ocean acidification and control of reef coral calcification by boundary layer limitation of proton fflux. Bull Mar Sci 87:639-657. https://doi. org/10.5343/bms.2010.1107

Jorissen FJ, Fontanier CE, Thomas E (2007) Paleoceanographical proxies based on deep-sea benthic foraminiferal assemblage characteristics. In: Hillaire-Marcel C, de Vernal A (eds) Proxies in late Cenozoic paleoceanography: Pt. 2: biological tracers and biomarkers. Elsevier, Amsterdam, pp 263-326

Kawahata H (2002) Suspended and settling particles in the Pacific. Deep-Sea Res || 49:5647-5664

Kawahata H, Nomura R, Matsumoto K, Nishi H (2015) Linkage of deep sea rapid acidification process and extinction of benthic foraminifera in the deep sea at the Paleocene/Eocene transition. Island Arc 24:301-316. https://doi.org/10. 1111/iar.12106

Kelly DC, Arnold AJ, Parker WC (1996) Paedomorphosis and the origin of the Paleogene planktonic foraminiferal genus Morozovella. Paleobiol 22:266-281

Kennett JP, Stott LD (1991) Abrupt deep-sea warming, palaeoceanographic changes and benthic extinctions at the end of the Palaeocene. Nature 353: 225-229. https://doi.org/10.1038/353225a0

Keul N, Langer G, de Nooijer LJ, Bijma J (2013) Effect of ocean acidification on the benthic foraminifera Ammonia sp. is caused by a decrease in carbonate ion concentration. Biogeosci 10:6185-6198. https://doi.org/10.5194/bg-10-6185-2013

Kleypas JA, Buddemeier RW, Archer D, Gattuso J-P, Langdon C, Opdyke BN (1999) Geochemical consequences of increased atmospheric carbon dioxide on coral reefs. Science 284:118-120

Kleypas JA, Feely RA, Fabry VJ, Langdon C, Sabine CL, Robbins LL (2006) Impacts of ocean acidification on coral reefs and other marine calcifiers: a guide for future research. Report of a workshop held on 18-20 April 2005, St. Petersburg, FL, sponsored by NSF, NOAA, and the U.S. Geological Survey, 88

Kleypas JA, Langdon C (2006) Coral reefs and changing seawater carbonate chemistry. In: Phinney JT, Hoegh-Guldberg O, Kleypas J, Skirving W, Strong A (eds) Coral Reefs and Climate Change: Science and Management. AGU Monograph Series, Coastal and Estuarine Studies, 61, American Geophysical Union, Washington, D. C, pp 73-110. https://doi.org/10.1029/61CE06

Kroeker KJ, Kordas RL, Crim R, Hendriks IE, Ramajo L, Singh GS, Duarte CM, Gattuso J-P (2013) Impacts of ocean acidification on marine organisms: quantifying sensitivities and interaction with warming. Glob Chang Biol 19: 1884-1896. https://doi.org/10.1111/gcb.12179

Kroeker KJ, Kordas RL, Crim RN, Singh GG (2010) Meta-analysis reveals negative yet variable effects of ocean acidification on marine organisms. Ecol Lett 13: 1419-1434. https://doi.org/10.1111/j.1461-0248.2010.01518.x

Kurihara $\mathrm{H}$ (2008) Effects of $\mathrm{CO}_{2}$-driven ocean acidification on the early developmental stages of invertebrates. Mar Ecol Prog Ser 373:275-284

Kuroda J, Ogawa N, Tanimizu M, Coffin M, Tokuyama H, Kitazato H, Ohkouchi N (2007) Contemporaneous massive subaerial volcanism and late cretaceous oceanic anoxic event 2. Earth Planet Sci Lett 256:211-223

Kuroyanagi A, da Rocha RE, Bijma J, Spero H, Russel AD, Eggins SM, Kawahata H (2013) Effect of dissolved oxygen concentration on planktonic foraminifera through 
laboratory culture experiments and implications for oceanic anoxic events. Mar Micropaleontol 101:28-32. https://doi.org/10.1016/j.marmicro.2013.04.005

Kuroyanagi A, Kawahata H, Suzuki A, Fujita K, Irie T (2009) Impacts of ocean acidification on large benthic foraminifers: results from laboratory experiments. Mar Micropaleontol 73:190-195

Kuroyanagi A, Toyofuku T, Nagai Y, Kimoto K, Nishi H, Takashima R, Kawahata H (2019) Effect of euxinic conditions on planktic foraminifers: culture experiments and implications for past and future environments. Paleoceanography and Paleoclimatology, [in press].

Larson RL (1991) Geological consequncres of superplumes. Geology 19:963-966 Leckie RM, Bralower TJ, Cashman R (2002) Oceanic anoxic events and plankton evolution: biotic response to tectonic forcing during the mid-cretaceous. Paleoceanography 17:1-29

Lee JJ (1998) "Living sands"-larger foraminifera and their endosymbiotic algae. Symbiosis 25:71-100

Lee JJ, Anderson R (1991) Symbiosis in foraminifera. In: Lee JJ, Anderson R (eds) Biology of foraminifera. Academic Press, New York

Li M, Peng C, Wang M, Xue W, Zhang K, Wang K, Shi G, Zhu Q (2017) The carbon flux of global rivers: a re-evaluation of amount and spatial patterns. Ecol Indic 80:40-51. https://doi.org/10.1016/j.ecolind.2017.04.049

Lohmann GP (1995) A model for variation in the chemistry of planktonic foraminifera due to secondary calcification and selective dissolution. Paleoceanogra 10:445-458

Lombard F, da Rocha RE, Bijma J, Gattuso J-P (2010) Effect of carbonate ion concentration and irradiance on calcification in planktonic foraminifera. Biogeos 7:247-255. https://doi.org/10.5194/bg-7-247-2010

Lombard F, Erez J, Michel E, Labeyrie L (2009) Temperature effect on respiration and photosynthesis of the symbiont-bearing planktonic foraminifera Globigerinoides ruber, Orbulina universa, and Globigerinella siphonifera. Limnol Oceanogra 54:210-218

Loya Y, Sakai K, Nakano Y, van Woesik R (2001) Coral bleaching: the winners and the losers. Ecol Lett 4:122-131. https://doi.org/10.1046/j.1461-0248.2001.00203.X

Ma Y, Aichmayer B, Paris O, Fratzl P, Meibom A, Metzler RA, Politi Y, Addadi L, Gilbert P, Weiner S (2009) The grinding tip of the sea urchin tooth exhibits exquisite control over calcite crystal orientation and mg distribution. Proc Nat Acad Sci 106:6048-6053

Mackenzie FT, May L, Lerman A (2002) Century-scale nitrogen and phosphorus controls of the carbon cycle. Chem Geol 190:13-32. https://doi.org/10.1016/ S0009-2541(02)00108-0

Maeda A, Fujita K, Horikawa K, Suzuki A, Yoshimura T, Tamenori Y, Kawahata H (2017) Evaluation of oxygen isotope and Mg/Ca ratios in high-magnesium calcite from benthic foraminifera as a proxy for water temperature. J Geophys Res 122:185-199

Manaka T, Otani S, Inamura A, Suzuki A, Aung T, Roachanakanan R, Ishiwa T, Kawahata $\mathrm{H}$ (2015a) Chemical weathering and long-term $\mathrm{CO}_{2}$ consumption in the Ayeyarwady and Mekong river basins in the Himalayas. J Geophys Res 120:1165-1175. https://doi.org/10.1002/2015JG002932

Manaka T, Ushie H, Araoka D, Inamura A, Suzuki A, Kawahata H (2013) Rapid alkalization in Lake Inawashiro, Fukushima, Japan: implications for future changes in the carbonate system of terrestrial waters. Aquat Geochem 19: 281-302. https://doi.org/10.1007/s10498-013-9195-6

Manaka T, Ushie H, Araoka D, Otani S, Inamura A, Suzuki A, Hossain HMZ, Kawahata $\mathrm{H}$ (2015b) Spatial and seasonal variation in surface water $p \mathrm{CO}_{2}$ in the Ganges, Brahmaputra, and Meghna Rivers on the Indian subcontinent. Aquat Geochem 21:437-458. https://doi.org/10.1007/s10498-015-9262-2

Manno C, Morata N, Bellerby R (2012) Effect of ocean acidification and temperature increase on the planktonic foraminifer Neogloboquadrina pachyderma (sinistral). Polar Biol 35:1311-1319. https://doi.org/10.1007/ s00300-012-1174-7

Marr JP, Baker JA, Carter L, Allan ASR, Dunbar GB, Bostock HC (2011) Ecological and temperature controls on Mg/Ca ratios of Globigerina bulloides from the Southwest Pacific Ocean. Paleoceanogra 26:PA2209. https://doi.org/10.1029/ 2010PA002059

Marubini F, Ferrier-Pagès C, Furla P, Allemand D (2008) Coral calcification responds to seawater acidification: a working hypothesis towards a physiological mechanism. Coral Reefs 27:491-499. https://doi.org/10.1007/ s00338-008-0375-6

McCulloch M, Falter J, Trotter J, Montagna P (2012) Coral resilience to ocean acidification and global warming through $\mathrm{pH}$ up-regulation. Nat Clim Chang 2:623-627

Millero FJ (2007) The marine inorganic carbon cycle. Chem Rev 107:308-341
Moriya K (2011) Development of the cretaceous greenhouse climate and the oceanic thermal structure. Paleont Res 15:77-88

Moriya K, Nishi H, Kawahata H, Tanabe K, Takayanagi Y (2003) Demersal habitat of late cretaceous ammonoids: evidence from oxygen isotopes for the Campanian (Late Cretaceous) northwestern Pacific thermal structure. Geology 31:167-170

Moriya K, Wilson PA, Friedrich O, Erbacher J, Kawahata H (2007) Testing for ice sheets during the mid-Cretaceous greenhouse using glassy foraminiferal calcite from the mid-Cenomanian tropics on demerara rise. Geology 35:615-618

Morse JW, Arvidson RS, Lüttge A (2007) Calcium carbonate formation and dissolution. Chem Rev 107:342-381

Morse JW, Mucci A, Millero FJ (1980) The solubility of calcite and aragonite in seawater of $35 \%$. Salinity at $25{ }^{\circ} \mathrm{C}$ and atmospheric pressure. Geochim Cosmochim Acta 44:85-94

Moy AD, Howard WR, Bray SG, Trull TW (2009) Reduced calcification in modern Southern Ocean planktonic foraminifera. Nat Geosci 2:276-280. https://doi. org/10.1038/ngeo460

Moya A, Tambutté S, Béranger G, Gaume B, Scimeca JC, Allemand D, Zoccola D (2008) Cloning and use of a coral 36B4 gene to study the differential expression of coral genes between light and dark conditions. Mar Biotechnol 10:653-663

Mucci A, Morse JW (1983) The incorporation of Mg2+ and Sr2+ into calcite overgrowths: influences of growth rate and solution composition. Geochim Cosmochim Acta 47:217-233

Nagai Y, Uematsu K, Wani R, Toyofuku T (2018) Reading the fine print: ultramicrostructures of foraminiferal calcification revealed using focused ion beam microscopy. Front Mar Sci 5:67. https://doi.org/10.3389/fmars.2018.00067

Naik SS, Naidu PD, Govil P, Godad S (2010) Relationship between weights of planktonic foraminifer shell and surface water $\mathrm{CO}_{3}{ }^{=}$concentration during the Holocene and last glacial period. Mar Geol 275:278-282

Nakamura T, Iguchi A, Suzuki A, Sakai K, Nojiri Y (2017) Effects of acidified seawater on calcification, photosynthetic efficiencies, and the recovery processes from strong light exposure in coral Stylophora pistillata. Mar Ecol 38:e12444. https://doi.org/10.1111/maec.12444

Nathorst AG (1911) On the value of the fossil floras of the Arctic regions as evidence of geological climates. Geol Mag Decade 5(8):217-225

Nishida K, Iguchi A, Ishimura T, Sakai K, Suzuki A (2014a) Skeletal isotopic responses of the Scleractinian coral Isopora palifera to experimentally controlled water temperatures. Geochem J 48:e9-e14. https://doi.org/10. 2343/geochemj.2.0317

Nishida K, Ishikawa K, Iguchi A, Tanaka Y, Sato M, Ishimura T, Inoue M, Nakamura T, Sakai K, Suzuki A (2014b) Skeletal oxygen and carbon isotope compositions of Acropora coral primary polyps experimentally cultured at different temperatures. Geochem Geophys Geosyst 15:2840-2849. https://doi. org/10.1002/2014GC005322

Norris RD (1996) Symbiosis as an evolutionary innovation in the radiation of Paleocene planktic foraminifera. Paleobiol 22:461-480

Norris RD, Röhl U (1999) Carbon cycling and chronology of climate warming during the Palaeocene/Eocene transition. Nature 401:775-778

Norris RD, Wilson PA (1998) Low-latitude sea-surface temperatures for the midcretaceous and the evolution of planktic foraminifera. Geology 26:823-826

Ohki S, Irie T, Inoue M, Shinmen K, Kawahata H, Nakamura T, Kato A, Nojiri Y, Suzuki A, Sakai K, van Woesik R (2013) Calcification responses of symbiotic and aposymbiotic corals to near-future levels of ocean acidification. Biogeosci 10:6807-6814. https://doi.org/10.5194/bg-10-6807-2013

Ohno Y, Fujita K, Toyofuku T, Nakamaura T (2016) Cytological observations of the large symbiotic foraminifer Amphisorus kudakajimensis using Calcein Acetoxymethyl Ester. PLoS One 11:e0165844

Ohno Y, Iguchi A, Shinzato C, Gushi M, Inoue M, Suzuki A, Sakai K, Nakamura T (2017b) Calcification process dynamics in coral primary polyps as observed using a calcein incubation method. Biochem Biophys Rep 9:289-294. https:// doi.org/10.1016/j.bbrep.2017.01.006

Ohno Y, Iguchi A, Shinzato C, Inoue M, Suzuki A, Sakai K, Nakamura T (2017a) An aposymbiotic primary coral polyp counteracts acidification by active $\mathrm{pH}$ regulation. Sci Rep 7:40324. https://doi.org/10.1038/srep40324

Oppo DW, Fairbanks RG (1989) Carbon isotope composition of tropical surface water during the past 22,000 years. Paleoceanogra 4:333-351

Orr JC, Fabry VJ, Aumont O, Bopp L, Doney SC, Feely RA, Gnanadesikan A, Gruber N, Ishida A, Joos F, Key RM, Lindsay K, Maier-Reimer E, Matear R, Monfray P, Mouchet A, Najjar RG, Plattner GK, Rodgers KB, Sabine CL, Sarmiento JL, Schlitzer R, Slater RD, Totterdell IJ, Weirig MF, Yamanaka Y, Yool A (2005) 
Anthropogenic ocean acidification over the twenty-first century and its impact on calcifying organisms. Nature 437:681-686

Oschlies A, Schulz KG, Riebesell U, Schmittner A (2008) Simulated $21^{\text {st }}$ century's increase in oceanic suboxia by $\mathrm{CO}_{2}$-enhanced biotic carbon export. Glob Biogeochem Cycles 22. https://doi.org/10.1029/2007GB003147

Ottway B, Hesemann M, Baubkus W. (2018) Foraminifera.Eu glossary by subject contents. https://www.foraminifera.eu/glossbs.php?cat2=wall\&aktion=suche Accessed 5 Dec 2018

Pagani M, Pedentchouk N, Huber M, Sluijs A, Schouten S, Brinkhuis H, Sinninghe Damsté JS, Dickens GR, Expedition 302 Scientists (2006) Arctic hydrology during global warming at the Palaeocene/Eocene thermal maximum. Nature 442:671-675. https://doi.org/10.1038/nature05043

Parker JH (2017) Ultrastructure of the test wall in modern porcelaneous foraminifera: implications for the classification of the Miliolida. J Foraminiferal Res 47:136-174

Pearson PN, Ditchfield PW, Singano J, Harcourt-Brown KG, Nicholas CJ, Olsson RK, Shackleton NJ, Hall MA (2001) Warm tropical sea surface temperatures in the late cretaceous and Eocene epochs. Nature 413:481-487

Pearson PN, Olsson RK, Huber BT, Hemleben C, Berggren WA (eds) (2006) Atlas of Eocene planktonic foraminifera. Cushman Foundation for Foraminiferal Research Special Publication 41. Cushman Foundation for Foraminiferal Research, Fredericksburg, pp. 513.

Pearson PN, van Dongen BE, Nicholas CJ, Pancost RD, Schouten S, Singano JM, Wade BS (2007) Stable warm tropical climate through the Eocene epoch. Geology 35:211-214

Peterson LC, Prell WL (1985) Carbonate dissolution in the recent sediments of eastern equatorial Indian Ocean: preservation patterns and carbonate loss above the lysocline. Mar Geol 64:259-290

Prazeres M, Uthicke S, Pandolfi JM (2016) Influence of local habitat on the physiological responses of large benthic foraminifera to temperature and nutrient stress. Sci Rep 6:21936

Pucéat E, Joachimski MM, Bouilloux A, Monna F, Bonin A, Motreuil S, Morinière $P$, Hénard S, Mourin J, Dera G, Quesne D (2010) Revised phosphate-water fractionation equation reassessing paleotemperatures derived from biogenic apatite. Earth Planet Sci Lett 298:135-142

Pucéat E, Lécuyer C, Donnadieu Y, Naveau P, Cappetta H, Ramstein G, Huber BT, Kriwet J (2007) Fish tooth $\delta^{18} \mathrm{O}$ revising late cretaceous meridional upper ocean water temperature gradients. Geology 35:107

Pucéat E, Lécuyer C, Sheppard SMF, Dromart G, Reboulet S, Grandjean P (2003) Thermal evolution of cretaceous Tethyan marine waters inferred from oxygen isotope composition of fish tooth enamels. Paleoceanogra 18. https://doi.org/10.1029/2002PA000823

Rasilo T, Hutchins RHS, Ruiz-González C, del Giorgio PA (2017) Transport and transformation of soil-derived $\mathrm{CO}_{2}, \mathrm{CH}_{4}$ and DOC sustain $\mathrm{CO}_{2}$ supersaturation in small boreal streams. Sci Total Environ 579:902-912. https://doi.org/10. 1016/j.scitotenv.2016.10.187

Raup DM, Sepkoski JJ (1982) Periodicity of extinctions in the geological past. Proc Natl Acad Sci U S A 81:801-805

Raymo ME (1991) Geochemical evidence supporting T. C. Chamberlin's theory of glaciation. Geology 19:344-347. https://doi.org/10.1130/00917613(1991)019<0344:GESTCC>2.3.CO;2

Raymo ME, Ruddiman WF, Froelich PN (1988) Influence of late Cenozoic mountain building on ocean geochemical cycles. Geology 16:649-653. https://doi.org/10.1130/0091-7613(1988)016<0649:IOLCMB>2.3.CO;2

Raymond PA, Hartmann J, Lauerwald R, Sobek S, McDonald C, Hoover M, Butman D, Striegl R, Mayorga E, Humborg C, Kortelainen P, Dürr H, Meybeck M, Ciais P, Guth P (2013) Global carbon dioxide emissions from inland waters. Nature 503:355-359. https://doi.org/10.1038/nature12760

Regnier $\mathrm{P}$, Friedlingstein $\mathrm{P}$, Ciais $\mathrm{P}$, Mackenzie FT, Gruber N, Janssens IA, Laruelle GG, Lauerwald R, Luyssaert S, Andersson AJ, Arndt S, Arnosti C, Borges AV, Dale AW, Gallego-Sala A, Goddéris Y, Goossens N, Hartmann J, Heinze C, Ilyina T, Joos F, LaRowe DE, Leifeld J, Meysman FJR, Munhoven G, Raymond PA, Spahni R, Suntharalingam P, Thullner M (2013) Anthropogenic perturbation of the carbon fluxes from land to ocean. Nat Geosci 6:597-607. https://doi.org/10.1038/ngeo1830

Reichart GJ, Brinkhuis H, Huiskamp F, Zachariasse WJ (2004) Hyperstratification following glacial overturning events in the northern Arabian Sea. Paleoceanogra 19:PA2013. https://doi.org/10.1029/2003PA000900

Reiss Z (1958) Classification of lamellar foraminifera. Micropaleontol 4:51-70

Richey JE, Melack JM, Aufdenkampe AK, Ballester VM, Hess LL (2002) Outgassing from Amazonian rivers and wetlands as a large tropical source of atmospheric $\mathrm{CO}_{2}$. Nature 416:617-620. https://doi.org/10.1038/416617a
Ries JB (2011a) A physicochemical framework for interpreting the biological calcification response to $\mathrm{CO}_{2}$-induces ocean acidification. Geochim Cosmochim Acta 75:4053-4064. https://doi.org/10.1016/j.gca.2011.04.025

Ries JB (2011b) Skeletal mineralogy in a high-CO2 world. J Exp Mar Biol Ecol 403: 54-64. https://doi.org/10.1016/j.jembe.2011.04.006

Ries JB, Cohen AL, McCorkle DC (2009) Marine calcifiers exhibit mixed responses to CO2-induced ocean acidification. Geology 37:1131-1134. https://doi.org/ 10.1130/G30210A.1

Robbins LL, Hansen ME, Kleypas JA, Meylan SC (2010) CO2calc-a user-friendly seawater carbon calculator for Windows, Max OS X, and iOS (iPhone): U.S. Geological Survey Open-File Report 2010-1280, p 17

Rodolfo-Metalpa R, Martin S, Ferrier-Pagès C, Gattuso JP (2010) Response of the temperate coral Cladocora caespitosa to mid-and long-term exposure to pCO2 and temperature levels projected for the year 2100 AD. Biogeosci 7: 289-300. https://doi.org/10.5194/bg-7-289-2010

Röhl U, Bralower TJ, Norris RD, Wefer G (2000) New chronology for the late Paleocene thermal maximum and its environmental implications. Geology 28:927-930. https://doi.org/10.1130/0091-7613(2000)28<927:NCFTLP>2.0.CO;2

Russell AD, Hönisch B, Spero HJ, Lea DW (2004) Effects of seawater carbonate ion concentration and temperature on shell $\mathrm{U}, \mathrm{Mg}$, and $\mathrm{Sr}$ in cultured planktonic foraminifera. Geochim Cosmochim Acta 68:4347-4361

Saris NEL, Carafoli E (2005) A historical review of cellular calcium handling, with emphasis on mitochondria. Biochemistry 70:187-194

Sarmiento JL, Dunne J, Gnanadesikan A, Key RM, Matsumoto K, Slater R (2002) A new estimate of the $\mathrm{CaCO}_{3}$ to organic carbon export ratio. Glob Biogeochem Cycles 1:1107. https://doi.org/10.1029/2002GB001919

Sarmiento JL, Gruber N (2006) Ocean biogeochemical cycles. Princeton Univ. Press, Princeton

Scheibner C, Speijer RP (2008) Late Paleocene-early Eocene Tethyan carbonate platform evolution - a response to long- and short-term paleoclimatic change. Earth Sci Rev 90:71-102

Schiebel R (2002) Planktic foraminiferal sedimentation and the marine calcite budget. Global Biogeochem Cycles 16: 3-1-3-21

Schiebel R, Hemleben C (2017) Planktic foraminifers in the modern ocean. Springer, Berlin, Heidelberg

Schmidt C, Heinz P, Kucera M, Uthicke S (2011) Temperature-induced stress leads to bleaching in larger benthic foraminifera hosting endosymbiotic diatoms. Limnol Oceanogra 56:1587-1602. https://doi.org/10.4319/lo.2011. 56.5.1587

Schmidt C, Kucera M, Uthicke S (2014) Combined effects of warming and ocean acidification on coral reef foraminifera Marginopora vertebralis and Heterostegina depressa. Coral Reefs 33:805-818

Schmidt C, Morard R, Prazeres M, Barak H, Kucera M (2016) Retention of high thermal tolerance in the invasive foraminifera Amphistegina lobifera from the eastern Mediterranean and the Gulf of Aqaba. Mar Biol 163:228

Scudder RP, Murray RW, Schindlbeck JC, Kutterolf S, Hauff F, Underwood MB, Gwizd S, Lauzon R, McKinley CC (2016) Geochemical approaches to the quantification of dispersed volcanic ash in marine sediment. Prog Earth Planet Sci 3:1. https://doi.org/10.1186/s40645-015-0077-y

Sekizawa A, Uechi H, Iguchi A, Nakamura T, Kumagai NH, Suzuki A, Sakai K, Nojiri $Y$ (2017) Intraspecific variations in responses to ocean acidification in two branching coral species. Mar Pollut Bull 122:282-287. https://doi.org/10.1016/ j.marpolbul.2017.06.061

Shackleton NJ, Kennett JP (1975) Paleotemperature history of the Cenozoic and the initiation of Antarctic glaciation: oxygen and carbon isotopic analysis in DSDP sites 277, 279 and 281. In: Kennettd JP, Houtz RE (eds) initial reports of the Deep Sea drilling project, 743-755. U.S. government printing office, Washington D.C

Sheppard CRC, Davy SK, Pilling GM (2009) The biology of coral reefs. Oxford University Press, New York

Sinutok S, Hill R, Kühl M, Doblin M, Ralph P (2014) Ocean acidification and warming alter photosynthesis and calcification of the symbiont-bearing foraminifera Marginopora vertebralis. Mar Biol 161:2143-2154

Spero HJ, Bijma J, Lea DW, Bemis BE (1997) Effect of seawater carbonate concentration on foraminiferal carbon and oxygen isotopes. Nature 390(6659):497-500

Stanley GD Jr (2006) Ecology, photosymbiosis and the evolution of modern coral reefs. Science 312:857-858

Stassen P, Thomas E, Speijer RP (2012) Integrated stratigraphy of the PaleoceneEocene thermal maximum in the New Jersey coastal plain: towards understanding the effects of global warming in a shelf environment. Paleoceanogra PA4210:1-17 
Suwa R, Nakamura M, Morita M, Shimada K, Iguchi A, Sakai K, Suzuki A (2010) Effects of acidified seawater on early life stages of scleractinian corals (genus Acropora). Fish Sci 76:93-99

Suzuki A, Gagan MK, Fabricius K, Isdale PJ, Yukino I, Kawahata H (2003) Skeletal isotope microprofiles of growth perturbations in Porites corals during the 1997-1998 mass bleaching event. Coral Reefs 22:357-369. https://doi.org/10. 1007/s00338-003-0323-4

Tada R, Murray RW (2016) Preface for the article collection "Land-Ocean linkages under the influence of the Asian monsoon". Prog Earth Planet Sci 3:24. https://doi.org/10.1186/s40645-016-0100-y

Tada R, Zheng H, Clift PD (2016) Evolution and variability of the Asian monsoon and its potential linkage with uplift of the Himalaya and Tibetan plateau. Prog Earth Planet Sci 3:4. https://doi.org/10.1186/s40645-016-0080-y

Takagi H, Kimoto K, Fujiki T, Kurasawa A, Moriya K, Hirano H (2016a) Ontogenetic dynamics of photosymbiosis in cultured planktic foraminifers revealed by fast repetition rate fluorometry. Mar Micropaleontol 122:44-52

Takagi H, Kimoto K, Fujiki T, Moriya K (2018) Effect of nutritional condition on photosymbiotic consortium of cultured Globigerinoidessacculifer (Rhizaria, Foraminifera). Symbiosis 76:25-39.

Takagi H, Moriya K, Ishimura T, Suzuki A, Kawahata H, Hirano H (2015) Exploring photosymbiotic ecology of planktic foraminifers from chamber-by-chamber isotopic history of individual foraminifers. Paleobiol 41:108-121

Takagi H, Moriya K, Ishimura T, Suzuki A, Kawahata H, Hirano H (2016b) Individual migration pathways of modern planktic foraminifers: chamber-by-chamber assessment of stable isotopes. Paleontol Res 20:268-284

Takahashi A, Kurihara H (2013) Ocean acidification does not affect the physiology of the tropical coral Acropora digitifera during a 5-week experiment. Coral Reefs 32:305-314. https://doi.org/10.1007/s00338-012-0979-8

Takashima R, Nishi H, Hayashi K, Okada H, Kawahata H, Yamanaka T, Fernando AG, Mampuku M (2009) Litho-, bio- and chemostratigraphy across the Cenomanian/Turonian boundary (OAE 2) in the Vocontian Basin of southeastern France. Palaeogeogra Palaeoclimatol Palaeoecol 273:61-74. https://doi.org/10.1016/j.palaeo.2008.12.001

Talge HK, Hallock P (2003) Ultrastructural responses in field-bleached and experimentally stressed Amphistegina gibbosa (class foraminifera). J Eukaryot Microbiol 50:324-333

Tambutté S, Holcomb M, Ferrier-Pagès C, Reynaud S, Tambutté S, Zoccola D, Allemand D (2011) Coral biomineralization: from the gene to the environment. J Exp Mar Biol Ecol 408:58-78

Tamenori Y, Yoshimura T, Luan NT, Hasegawa H, Suzuki A, Kawahata H, Iwasaki N (2014) Identification of the chemical form of sulfur compounds in the Japanese pink coral (Corallium elatius) skeleton using mu-XRF/XAS speciation mapping. J Struct Biol 186:214-223. https://doi.org/10.1016/j.jsb.2014.04.001

Tanaka Y, Iguchi A, Inoue M, Mori C, Sakai K, Suzuki A, Kawahata H, Nakamura T (2013) Microscopic observation of symbiotic and aposymbiotic juvenile corals in nutrient-enriched seawater. Mar Pollut Bull 68:93-98. https://doi.org/ 10.1016/j.marpolbul.2012.12.017

Tanaka Y, Iguchi A, Nishida K, Inoue M, Nakamura T, Suzuki A, Sakai K (2014) Nutrient availability affects the response of juvenile corals and the endosymbionts to ocean acidification. Limnol Oceanogr 59:1468-1476. https://doi.org/10.4319/lo.2014.59.5.1468

Tanaka Y, Miyajima T, Koike I, Hayashibara T, Ogawa H (2007) Imbalanced coral growth between organic tissue and carbonate skeleton caused by nutrient enrichment. Limnol Oceanogr 52:1139-1146. https://doi.org/10.4319/lo.2007.52.3.1139

Tarduno JA, Brinkman DB, Renne PR, Cottrell RD, Scher H, Castillo P (1998) Evidence for extreme climatic warmth from Late Cretaceous Arctic vertebrates. Science 282:2241-2244

ter Kuile B, Erez J, Padan E (1989) Mechanisms for the uptake of inorganic carbon by two species of symbiont-bearing foraminifera. Mar Biol 103:241-251

Thunell RC, Curry WB, Honjo S (1983) Seasonal variation in the flux of planktonic foraminifera: time series sediment trap results from the Panama Basin. Earth Planet Sci Lett 64:44-55

Toggweiler JR, Sarmiento JL (1985) Glacial to interglacial changes in atmospheric carbon dioxide: the critical role of ocean surface water in high latitudes. In: Sundquist ET, Broecker WS (eds) The carbon cycle and atmospheric $\mathrm{CO}_{2}$ : natural variations Archean to present. Geophys Monogr 32. American Geophysical Union, Washington DC

Toyofuku T, de Nooijer LJ, Yamamoto H, Kitazato H (2008) Real-time visualization of calcium ion activity in shallow benthic foraminiferal cells using the fluorescent indicator Fluo-3 AM. Geochem Geophys Geosyst 9:005005. https://doi.org/10.1029/2007gc001772
Toyofuku T, Kitazato H, Kawahata H, Tsuchiya M, Nohara M (2000) Evaluation of $\mathrm{Mg} / \mathrm{Ca}$ thermometry in foraminifera: comparison of experimental results and measurements in nature. Paleoceanogra 15:456-464

Toyofuku T, Matsuo MY, De Nooijer LJ, Nagai Y, Kawada S, Fujita K, Reichart G-J, Nomaki H, Tsuchiya M, Sakaguchi H (2017) Proton pumping accompanies calcification in foraminifera. Nat Commun 8:14145

Upchurch GR, Kiehl J, Shields C, Scherer J, Scotese C (2015) Latitudinal temperature gradients and high-latitude temperatures during the latest cretaceous: congruence of geologic data and climate models. Geology 43: 683-686

Van Dam JW, Negri AP, Mueller JF, Altenburger R, Uthicke S (2012) Additive pressures of elevated sea surface temperatures and herbicides on symbiontbearing foraminifera. PLoS One 7:e33900

van Hinsbergen DJJ, de Groot LV, van Schaik SJ, Spakman W, Bijl PK, Sluijs A, Langereis CG, Brinkhuis H (2015) A Paleolatitude calculator for paleoclimate studies. PLoS One 10:e0126e946

van Woesik R, Sakai K, Ganase A, Loya Y (2011) Revisiting the winners and the losers a decade after coral bleaching. Mar Ecol Prog Ser 434:67-76

Veron J (2008) Mass extinctions and ocean acidification: biological constraints on geological dilemmas. Coral Reefs 27:459-472

Wade BS, Al-Sabouni N, Hemleben C, Kroon D (2008) Symbiont bleaching in fossil planktic foraminifera. Evol Ecol 22:253-265

Weinmann AE, Rödder D, Lötters S, Langer MR (2013) Heading for new shores: projecting marine distribution ranges of selected larger foraminifera. PLoS One 8:e62182

Wiegand BA, Chadwick OA, Vitousek PM, Wooden JL (2005) Ca cycling and isotopic fluxes in forested ecosystems in Hawaii. Geophys Res Lett 32:L11404

Williams DE, Hallock P (2004) Bleaching in Amphistegina gibbosa d'Orbigny (class foraminifera): observations from laboratory experiments using visible and ultraviolet light. Mar Biol 145:641-649

Wilson PA, Norris RD, Cooper MJ (2002) Testing the cretaceous greenhouse hypothesis using glassy foraminiferal calcite from the core of the Turonian tropics on demerara rise. Geology 30:607-610

Wittmann AC, Pörtner H-O (2013) Sensitivities of extant animal taxa to ocean acidification. Nat Clim Chang 3:995-1001

Yamamura M, Kawahata H, Matsumoto K, Takashima R, Nishi H (2007) Paleoceanography of the northwestern Pacific during the Albian. Palaeogeogra Palaeoclimat Palaeoecol 254:477-491. https://doi.org/10.1016/j. palaeo.2007.07.002

Yamano H, Sugihara K, Nomura K (2011) Rapid poleward range expansion of tropical reef corals in response to rising sea surface temperatures. Geophys Res Lett 38:L04601. https://doi.org/10.1029/2010GL046474

Yellowlees D, Rees TAV, Leggat W (2008) Metabolic interactions between algal symbionts and invertebrate hosts. Plant Cell Env 31:679-694. https://doi.org/ 10.1111/j.1365-3040.2008.01802.x

Yoshimura T, Tamenori Y, Suzuki A, Kawahata H, Iwasaki N, Hasegawa H, Nguyen LT, Kuroyanagi A, Yamazaki T, Kuroda J (2017) Altervalent substitution of sodium for calcium in biogenic calcite and aragonite. Geochim Cosmochim Acta 202:21-38

Yoshimura T, Tamenori Y, Takahashi O, Nguyen LT, Hasegawa H, Iwasaki N, Kuroyanagi A, Suzuki A, Kawahata H (2015) Mg coordination in biogenic carbonates constrained by theoretical and experimental XANES. Earth Planet Sci Lett 421:68-74. https://doi.org/10.1016/j.epsl.2015.03.048

Zachos J, Pagani M, Sloan L, Thomas E, Billups K (2001) Trends, rhythms, and aberrations in global climate $65 \mathrm{Ma}$ to present. Science 292:686-693

Zachos JC, Dickens GR, Zeebe RE (2008) An early Cenozoic perspective on greenhouse warming and carbon-cycle dynamics. Nature 451:279-283

Zachos JC, Röhl U, Schellenberg SA, Sluijs A, Hodell DA, Kelly DC, Thomas E, Nicolo M, Raffi I, Lourens L, McCarren H, Kroon D (2005) Rapidacidification of the ocean during the Paleocene-Eocene thermal maximum. Science 308 : $1611-1615$

Zachos JC, Stott LD, Lohmann KC (1994) Evolution of early Cenozoic marine temperatures. Paleoceanography 9:353-387 